Studies by the U.S. Geological Survey in Alaska, 2008-2009

\title{
The Cannery Formation-Devonian to Early Permian Arc-Marginal Deposits Within the Alexander Terrane, Southeastern Alaska
}

Professional Paper 1776-B

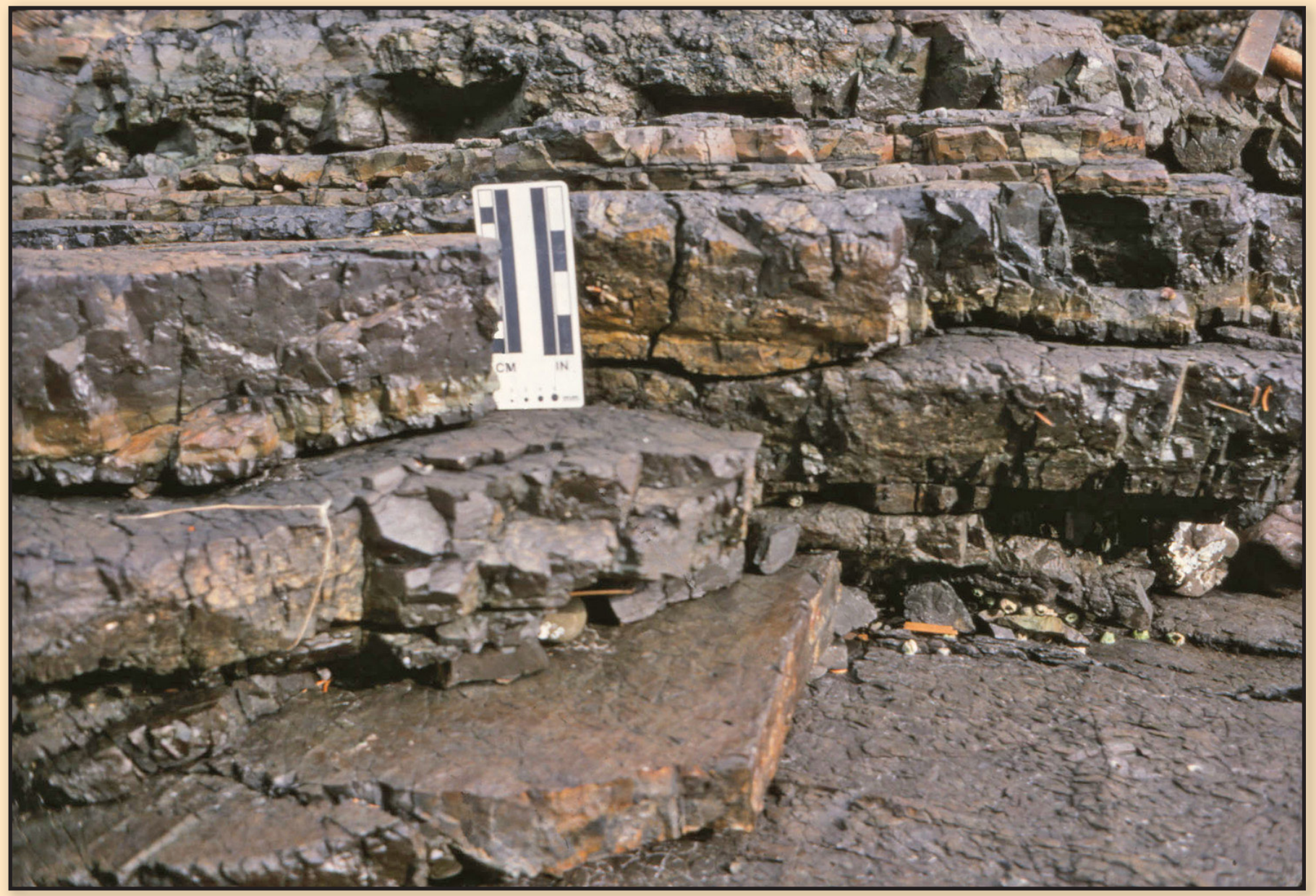

U.S. Department of the Interior

U.S. Geological Survey 
FRONT COVER

Rocks of the Cannery Formation in the type area Cannery Cove. 
Studies by the U.S. Geological Survey in Alaska, 2008-2009

\section{The Cannery Formation—Devonian to Early Permian Arc-Marginal Deposits Within the Alexander Terrane, Southeastern Alaska}

By Susan M. Karl, Paul W. Layer, Anita G. Harris, Peter J. Haeussler, and Benita L. Murchey

Professional Paper 1776-B

U.S. Department of the Interior

U.S. Geological Survey 


\section{U.S. Department of the Interior KEN SALAZAR, Secretary}

\section{U.S. Geological Survey \\ Marcia K. McNutt, Director}

\section{U.S. Geological Survey, Reston, Virginia: 2010}

This report and any updates to it are available online at:

http://pubs.usgs.gov/pp/1776/b/

For additional information write to:

U.S. Geological Survey

Box 25046, Mail Stop 421, Denver Federal Center

Denver, C0 80225-0046

Additional USGS publications can be found at:

http://geology.usgs.gov/index.htm

For more information about the USGS and its products:

Telephone: 1-888-ASK-USGS (1-888-275-8747)

World Wide Web: http://www.usgs.gov/

Any use of trade, product, or firm names in this publication is for descriptive purposes only and does not imply endorsement by the U.S. Government.

Although this report is in the public domain, it may contain copyrighted materials that are noted in the text. Permission to reproduce those items must be secured from the individual copyright owners.

Suggested Citation

Karl, S.M., Layer, P.W., Harris, A.G., Haeussler, P.J., and Murchey, B.L., 2010, The Cannery Formation—Devonian to Early Permian arc-marginal deposits within the Alexander Terrane, Southeastern Alaska, in Dumoulin, J.A., and Galloway, J.P., eds., Studies by the U.S. Geological Survey in Alaska, 2008-2009: U.S. Geological Survey Professional Paper 1776-B, 45 p. 


\section{Contents}

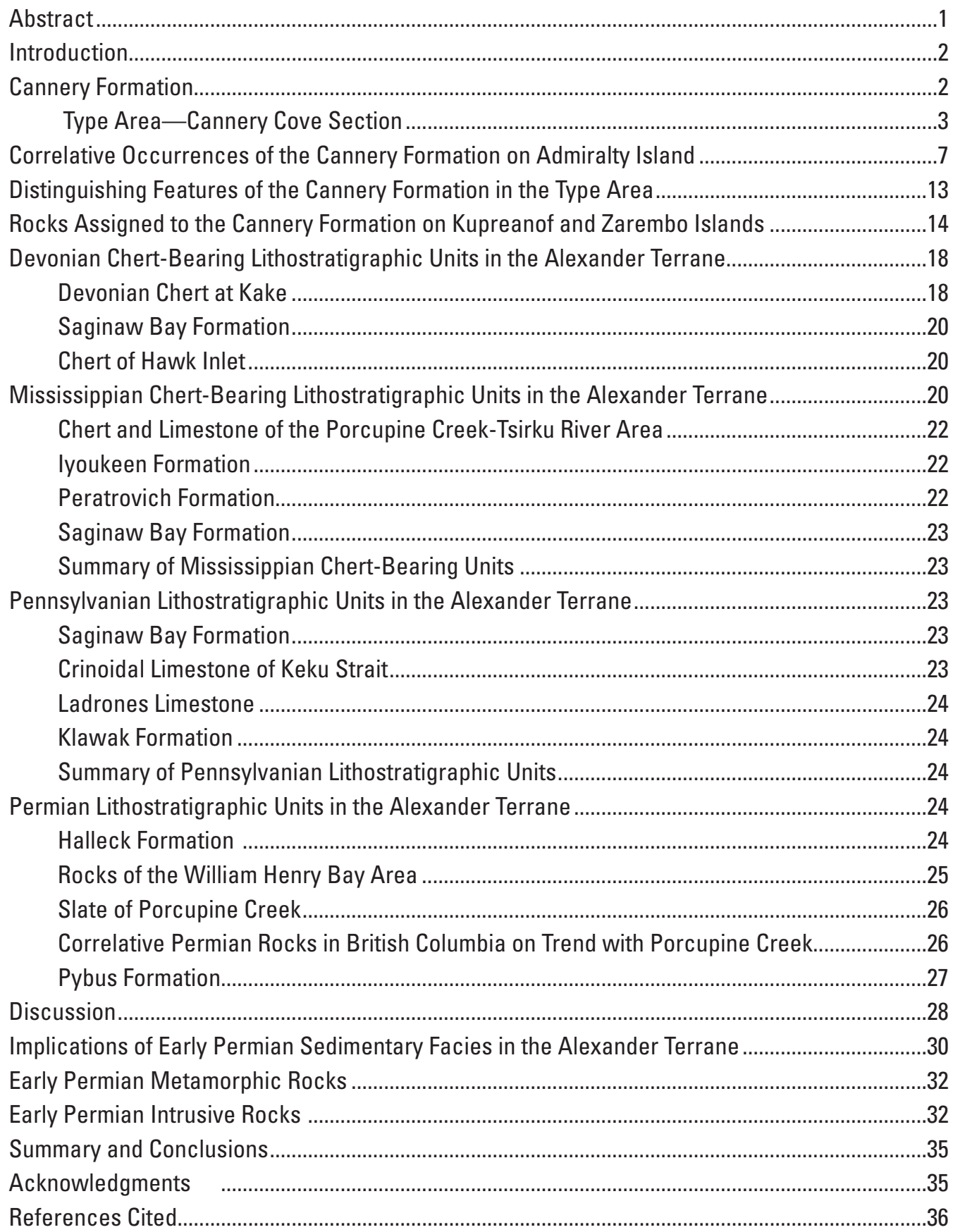




\section{Figures}

1. Southeastern Alaska, showing location of the Alexander terrane ...........................................

2. Geologic map showing distribution of early Permian rocks, and rocks that were metamorphosed during the early Permian ..........................................................

3. Late Devonian through Permian lithostratigraphic columns ..................................................5

4. Rocks of the Cannery Formation dated by fossils in type area ...............................................

5. Photomicrographs of rocks of the Cannery Formation at Cannery Cove .................................7

6. Photomicrographs of argillite of the Cannery Formation at Snug Cove..................................11

7. Photomicrographs of rocks of the Cannery Formation at Windfall Harbor ..............................14

8. Compositional diagrams showing immobile-trace-element chemistry of volcanic rocks associated with the Cannery Formation on Admiralty Island ................15

9. Rocks of the Cannery Formation on Windfall and Kupreanof Islands....................................16

10. Photomicrographs of rocks of the Cannery Formation on Kuprean of Island...........................17

11. Deformed slaty argillite of the Cannery Formation in southeastern Alaska............................18

12. Southeastern Alaska, showing the distribution of Late Devonian, Early Mississippian, and Late Mississippian black chert and limestone in the Alexander terrane ....................19

13. Bedding and a rugose coral and volcaniclastic rocks from the type locality of the Halleck Formation at Halleck Harbor, Saginaw Bay, southeastern Alaska (figs. 1, 2). Limestone of the Pybus Formation overlying pillow basalt of the Halleck Formation and fossil hash of the Pybus Formation are from exposures in Saginaw Bay.............................................25

14. Southeastern Alaska, showing distribution of the late Permian Pybus Formation and age-equivalent rocks in the Alexander terrane

15. ${ }^{40} \mathrm{Ar} /{ }^{39} \mathrm{Ar}$ age spectra for minerals dated from metamorphic rocks on Admiralty Island

16. Southeastern Alaska, showing distribution of Permian sedimentary, metamorphic, and igneous rocks and inferred model for their tectonic setting.

17. Compositional diagrams showing geochemical affinities of Permian intrusive rocks of the Alexander terrane

\section{Tables}

1. Fossil ages reported for the Cannery Formation and equivalent rocks..................................

2. Fossil ages reported for the Pybus Formation and equivalent rocks......................................12

3. Radiometric data for Permian metamorphic and igneous rocks

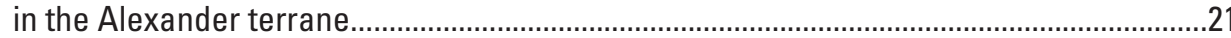

4. Chemical analyses of Permian intrusive rocks..........................................................................3

\section{Appendix}

Argon analytical data for Permian metamorphic and igneous rocks 


\title{
The Cannery Formation-Devonian to Early Permian Arc-Marginal Deposits Within the Alexander Terrane, Southeastern Alaska
}

\author{
By Susan M. Karl, Paul W. Layer, Anita G. Harris, Peter J. Haeussler, and Benita L. Murchey
}

\section{Abstract}

The Cannery Formation consists of green, red, and gray ribbon chert, siliceous siltstone, graywacke-chert turbidites, and volcaniclastic sandstone. Because it contains early Permian fossils at and near its type area in Cannery Cove, on Admiralty Island in southeastern Alaska, the formation was originally defined as a Permian stratigraphic unit. Similar rocks exposed in Windfall Harbor on Admiralty Island contain early Permian bryozoans and brachiopods, as well as Mississippian through Permian radiolarians. Black and green bedded chert with subordinate lenses of limestone, basalt, and graywacke near Kake on Kupreanof Island was initially correlated with the Cannery Formation on the basis of similar lithology but was later determined to contain Late Devonian conodonts. Permian conglomerate in Keku Strait contains chert cobbles inferred to be derived from the Cannery Formation that yielded Devonian and Mississippian radiolarians. On the basis of fossils recovered from a limestone lens near Kake and chert cobbles in the Keku Strait area, the age of the Cannery Formation was revised to Devonian and Mississippian, but this revision excludes rocks in the type locality, in addition to excluding bedded chert on Kupreanof Island east of Kake that contains radiolarians of Late Pennsylvanian and early Permian age. The black chert near Kake that yielded Late Devonian conodonts is nearly contemporaneous with black chert interbedded with limestone that also contains Late Devonian conodonts in the Saginaw Bay Formation on Kuiu Island. The chert cobbles in the conglomerate in Keku Strait may be derived from either the Cannery Formation or the Saginaw Bay Formation and need not restrict the age of the Cannery Formation, regardless of their source. The minimum age of the Cannery Formation on both Admiralty Island and Kupreanof Island is constrained by the stratigraphically overlying fossiliferous Pybus Formation, of late early and early late Permian age. Because bedded radiolarian cherts on both Admiralty and Kupreanof Islands contain radiolarians as young as Permian, the age of the Cannery Formation is herein extended to Late Devonian through early Permian, to include the early Permian rocks exposed in its type locality. The Cannery Formation is folded and faulted, and its stratigraphic thickness is unknown but inferred to be several hundred meters. The Cannery Formation represents an extended period of marine deposition in moderately deep water, with slow rates of deposition and limited clastic input during Devonian through Pennsylvanian time and increasing argillaceous, volcaniclastic, and bioclastic input during the Permian.

The Cannery Formation comprises upper Paleozoic rocks in the Alexander terrane of southeastern Alaska. In the pre-Permian upper Paleozoic, the tectonic setting of the Alexander terrane consisted of two or more evolved oceanic arcs. The lower Permian section is represented by a distinctive suite of rocks in the Alexander terrane, which includes sedimentary and volcanic rocks containing early Permian fossils, metamorphosed rocks with early Permian cooling ages, and intrusive rocks with early Permian cooling ages, that form discrete northwest-trending belts. After restoration of $180 \mathrm{~km}$ of dextral displacement of the ChilkatChichagof block on the Chatham Strait Fault, these belts consist, from northeast to southwest, of (1) bedded chert, siliceous argillite, volcaniclastic turbidites, pillow basalt, and limestone of the Cannery Formation and the Porcupine Slate of Gilbert and others (1987); (2) greenschist-facies Paleozoic metasedimentary and metavolcanic rocks that have Permian cooling ages; (3) silty limestone and calcareous argillite interbedded with pillow basalt and volcaniclastic rocks of the Halleck Formation and the William Henry Bay area; and (4) intermediate-composition and syenitic plutons. These belts correspond to components of an accretionary complex, contemporary metamorphic rocks, forearc-basin deposits, and the roots of a volcanic arc, respectively. The similar early Permian sedimentary, metamorphic, and igneous ages are inferred to represent an arc complex that resulted from juxtaposition of a structural lower plate consisting of metamorphosed Paleozoic arc rocks of the Alexander terrane exposed on Admiralty Island, and a structural upper plate consisting of stratigraphically distinct, unmetamorphosed Paleozoic arc rocks representing another component of the Alexander terrane exposed on Chichagof, Kuiu, and Prince of Wales Islands. The Cannery Formation is associated with the lower-plate package. A volcanic arc 
with magmatic ages ranging from 293 to $278 \mathrm{Ma}$ formed during subduction of the basin between these two (or more) components of the Alexander terrane in southeastern Alaska. Metamorphic-mineral-cooling ages ranging from 273 to $260 \mathrm{Ma}$ are interpreted to date an early Permian orogenic event. Both the early Permian lower- and upper-plate rocks are unconformably overlain by late early and early late Permian limestone, dolostone, and conglomerate of the Pybus Formation that provide a minimum age for this collision.

\section{Introduction}

The purpose of this report is to clarify the age and stratigraphic position of the Cannery Formation as defined by Loney (1964), modified by Muffler (1967), and redefined by Jones and others (1981), and to delineate its depositional environment and tectonic setting. Undated rocks that were provisionally assigned to the Cannery Formation by Muffler (1967) yielded much older fossils than those from rocks at the type area, but although rocks in the type area contain Permian fossils, the age of the unit was revised to Devonian and Mississippian by Jones and others (1981). We evaluate the composition and distribution of rocks of Devonian through Permian age in the Alexander terrane and the utility of the Cannery Formation as originally defined in comparison with the utility of its present definition that excludes rocks in the original type area. Clarification of the age and stratigraphic position of the Cannery Formation is important for documenting the depositional and structural history of the Alexander terrane (fig. 1). The Cannery Formation and equivalent units record a major tectonic event in the Alexander terrane, comprise basement to a belt of Late Triassic volcanogenic massive sulfide (VMS) deposits in the Alexander terrane, and provide insights into the tectonic setting of these VMS deposits. We herein redefine the Cannery Formation to include rocks of similar age and composition to those exposed at the type locality of the unit in Cannery Cove on Admiralty Island, as originally defined by Loney (1964), and we extend the age of the unit to include rocks assigned to the Cannery Formation by Muffler (1967), Jones and others (1981), and Brew and others (1984).

\section{Cannery Formation}

The Cannery Formation was named for thinly interbedded chert, argillite, and graywacke exposed in Cannery Cove on the southwest shore of Pybus Bay on Admiralty Island (figs. 2, 3; Loney, 1964). The unit crops out almost continuously from about $6 \mathrm{~km}$ south of Cannery Cove to the north shore of Donkey Bay (fig. 2), a distance of almost $10 \mathrm{~km}$. In Pybus and Gambier Bays, the unit includes volcaniclastic graywacke, pillow basalt, and pillow breccia. The chert, argillite, and graywacke vary widely in color, ranging from red through gray to bright spruce green, but are predominantly green and gray (fig. 4). The chert and argillite contain radiolarians and sponge spicules. Bryozoan debris of Permian age was recovered from massive calcareous graywacke interbedded with chert and argillite at the top of the type section in Donkey Bay and near the mouth of Pybus Bay (locs. 20 and 21, fig. 2 and table 1). Corals, a brachiopod, and bryozoans from three additional fossil localities in graywacke, chert, and argillite between Pybus and Gambier Bays (locs. 17-19, fig. 2 and table 1) yielded similar ages (Loney, 1964; see Alaska Paleontologic Database, http://www.alaskafossil.org/). At Donkey Bay, the fossil locality is near the contact with overlying fossiliferous limestone and dolostone of the Pybus Formation that contains Permian brachiopods (loc. 45, fig. 2 and table 2; Loney, 1964; see Alaska Paleontologic Database, http://www.alaskafossil. org/), which provide a minimum age for the Cannery Formation. The sandstone at Cannery Cove is a graywacke containing feldspar, mafic volcanic fragments, calcareous bioclastic debris, and less than 8 volume percent quartz in a matrix that constitutes at least 15 volume percent of the sandstone (Loney, 1964). The graywacke sandstone grades to chert within single turbidite beds. Radiolarians are distributed throughout the beds in both the sandstone and the chert (figs. $5 B-5 D$ ). Feldspar clasts in the sandstone and argillite include andesine and albite; the albite is interpreted to be secondary (Loney, 1964). Other secondary minerals include quartz, chlorite, calcite, and clay (fig. $5 A$ ). Locally, sandstone and conglomerate of the Cannery Formation contain angular clasts of quartz-veined black chert resembling chert of the underlying Hood Bay Formation. Conglomerate of the overlying Pybus Formation and Hyd Group contains angular to rounded clasts of red and blue-green bedded chert that resemble chert of the Cannery Formation. Although no upper or lower depositional contacts of the Cannery Formation have been observed, clasts of underlying veined black chert in conglomerate of the Cannery Formation and clasts of red and green chert of the Cannery Formation in overlying limestone of the Pybus Formation and in Late Triassic conglomerate of the Hyd Group are inferred to indicate stratigraphic unconformities above and below the Cannery Formation. The Hood Bay Formation consists of deformed, quartz-veined black chert and argillite containing Ordovician graptolites (Carter, 1977). The chert and argillite grade upward to carbonaceous argillite, chert, chert sandstone grit, meter-scale lenses of pillow basalt, and thinly laminated black limestone containing Silurian-Devonian conodonts (A.G. Harris, written commun., 1995). Crisscrossing quartz veinlets in the Hood Bay Formation, which are absent in the Cannery Formation, are inferred to represent a pre-Cannery deformation event.

An argillite-dominant facies of the Cannery Formation was mapped in the Snug Cove area of Gambier Bay by Lathram and others (1965) (fig. 6). Graywacke-chert turbidite beds in Windfall Harbor (fig. 2), similar to those in Cannery Cove, contain Mississippian and Mississippian through Permian radiolarians (loc. 16, fig. 2 and table 1; B.L. Murchey, written commun., 1997). Radiolarians are common in the chert 
(fig. 7B-7D), but also occur in the arenaceous parts of turbidite beds (figs. $7 C, 7 D$ ). A maximum age of Mississippian is inferred for the Cannery Formation on Admiralty Island on the basis of Mississippian radiolarians from the graywacke-chert turbidites in Windfall Harbor and the unconformity between the Cannery Formation and the Ordovician through Devonian Hood Bay Formation.

\section{Type Area-Cannery Cove Section}

At Cannery Cove on Admiralty Island, the type area of the Cannery Formation, the basal and upper contacts of the unit are not exposed. The section is too deformed to measure, but the base is inferred to be near the back of the cove, behind which the Hood Bay Formation is exposed on the ridge, and

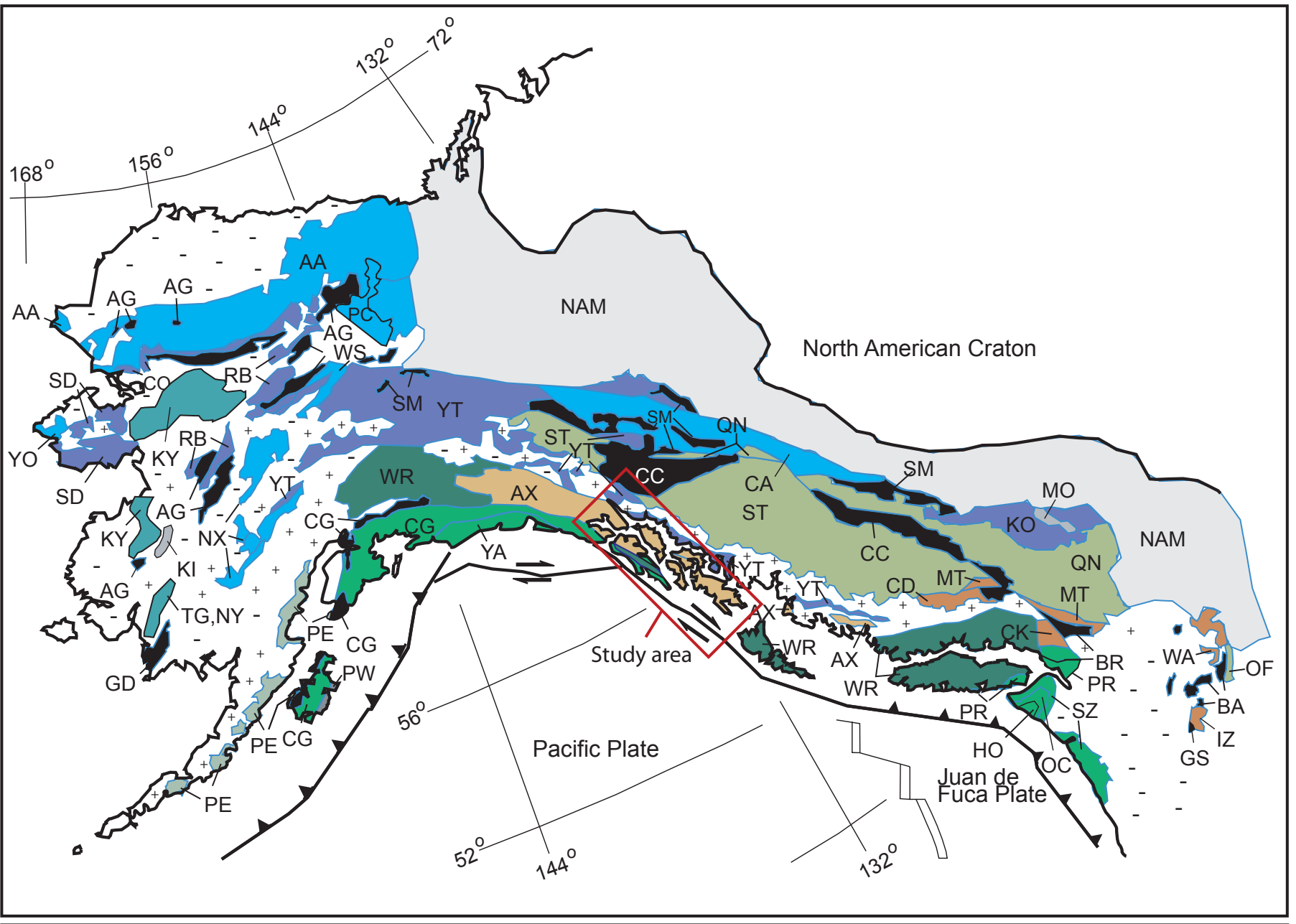

\section{EXPLANATION}

\section{Craton}

NAM North American cratonal margin

Cratonal terrane

\section{Pericratonic Terranes}

Proximal pericratonal terrane

Distal pericratonal terrane

\section{Accreted Terranes}

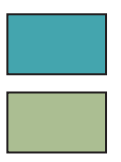

Upper Mesozoic island-arc terrane

Lower Mesozoic island-arc terrane

PE Peninsular terrane

WR Wrangellia

Paleozoic and Mesozoic arc terrane

AX

Alexander terrane

\section{Accretionary Complexes}

Oceanic basalt, volcaniclastic, and pelagic rocks

Mixed-source clastic rocks

Overlap and Intrusive Rocks

\begin{tabular}{|l|l}
\hline+ & + \\
+ &
\end{tabular}

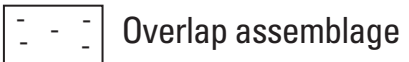

Contact

$\rightleftharpoons$ Strike-slip fault

$\wedge$ _ Thrust fault

Figure 1. Southeastern Alaska, showing location of the Alexander terrane (modified from Nokleberg and others, 2000, with permission). 


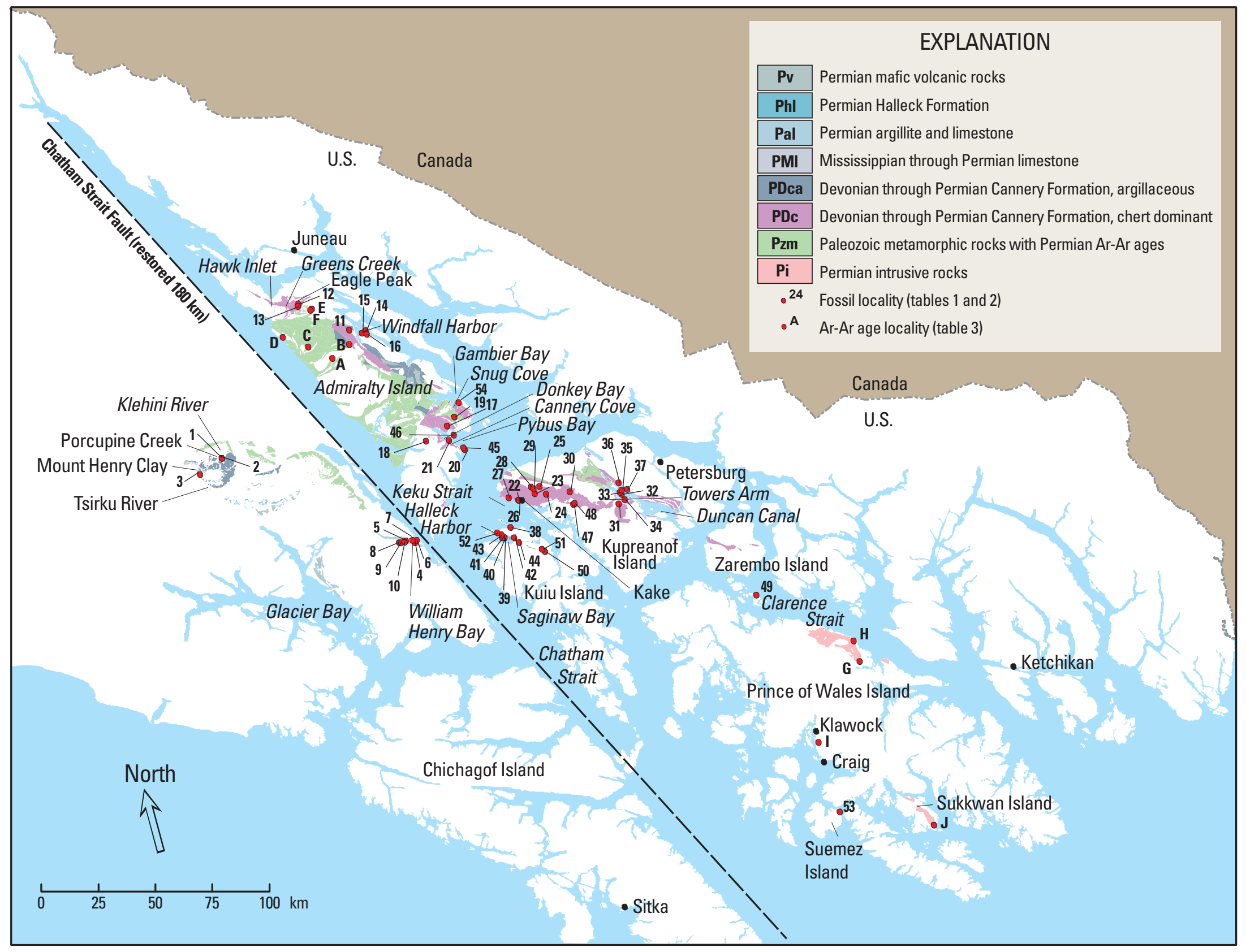

Figure 2. Geologic map showing distribution of early Permian rocks, and rocks that were metamorphosed during the early Permian, in the Alexander terrane, southeastern Alaska (fig. 1). Rocks south and west of the Denali-Chatham Strait dextral fault have been restored $180 \mathrm{~km}$ to better reflect Permian paleogeography. 


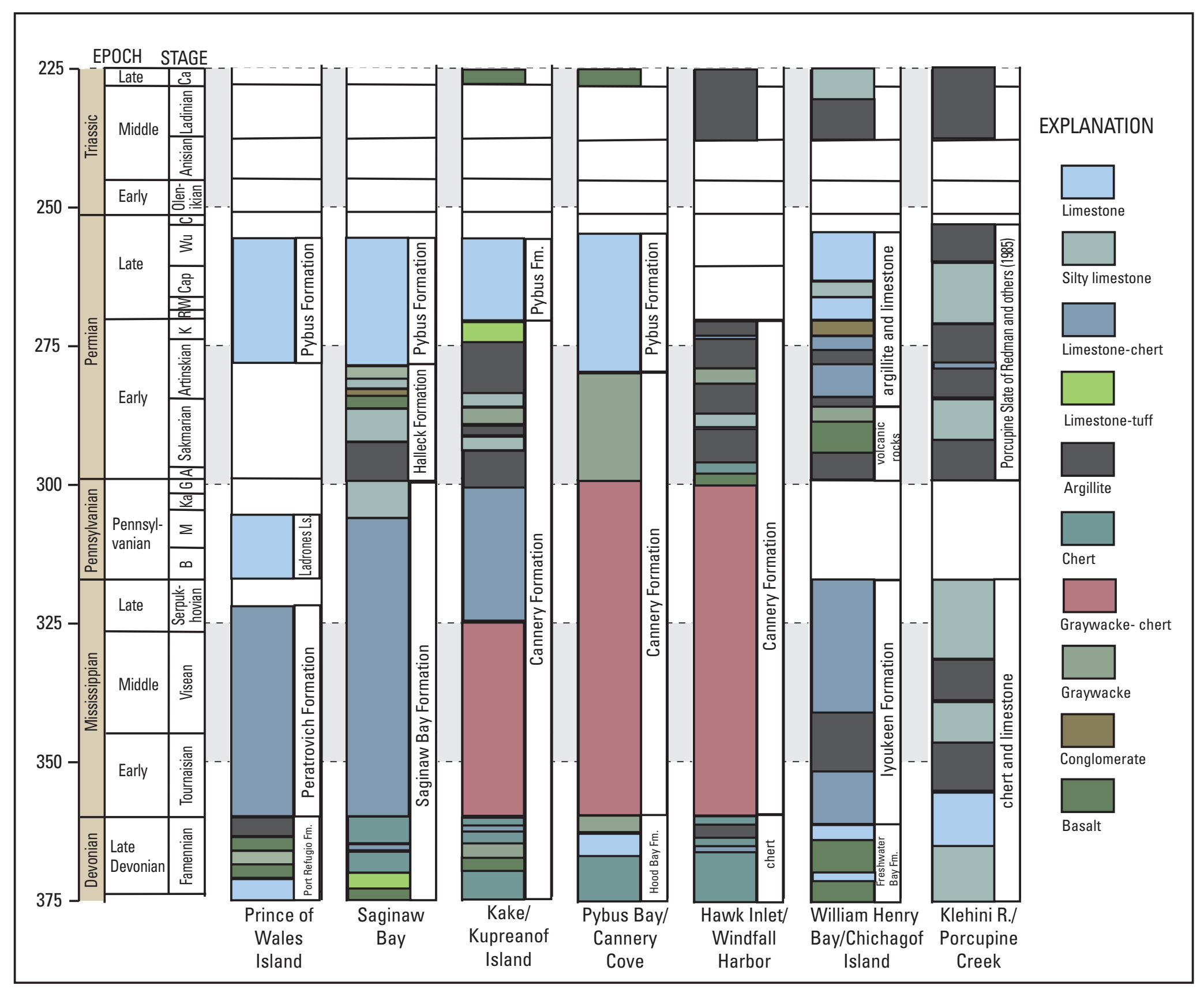

Figure 3. Late Devonian through Permian lithostratigraphic columns for key areas in the Alexander terrane, southeastern Alaska (figs. 1,2). Time scale used is that of Gradstein and others (2004). 

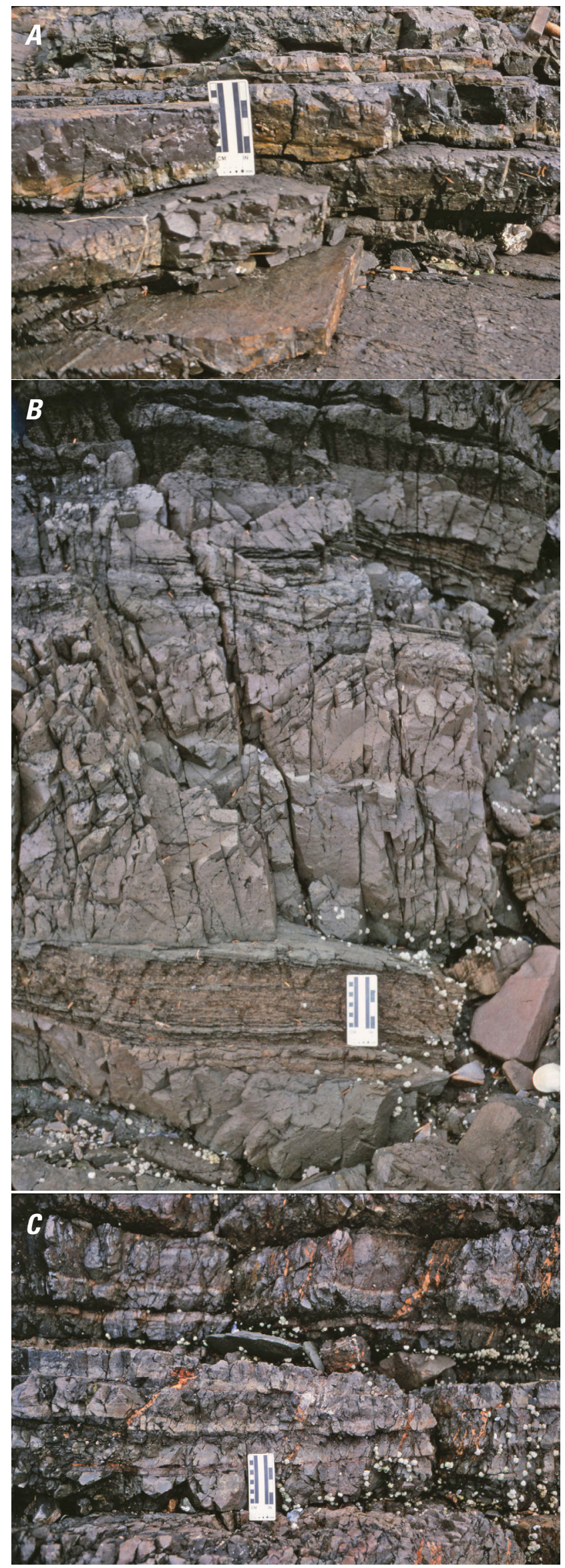

the top of the section is slightly north and east of Donkey Bay. Because graywacke is present throughout the section, the type section is shown in figure 3 to consist of a chert-dominant graywacke-chert turbidite section and a graywacke-argillite turbidite section. The basal rocks of the exposed Cannery section consist mainly of 10 to $30 \mathrm{~m}$ of blue-green radiolarian ribbon chert, in graded beds 2 to $15 \mathrm{~cm}$ thick, with rare intercalations of graywacke grit. The ribbon chert grades upward to a middle section, more than $50 \mathrm{~m}$ thick, consisting of 75 percent bedded gray-green chert, 20 percent graywacke-chert turbidites (fig. $4 A$ ), and less than 5 percent green argillite. The turbidites consist of fine- to coarse-grained volcaniclastic and bioclastic graywacke that grades to radiolarian chert within individual turbidite beds. Radiolarians are distributed throughout the sandstone and chert. This chert-dominant section grades upward to a graywacke-dominant section, more than $30 \mathrm{~m}$ thick, consisting of graywacke-argillite turbidites, with subordinate 1- to 3 -cm thick beds of greenish-gray radiolarian chert and cherty argillite (fig. 5). The graywacke-argillitedominant part of the section includes rare meter-scale lenses of orange-weathering carbonate and an argillite-matrix debris flow that contains blocks of intraformational graywackeargillite turbidites. This section is overlain by thick-bedded, meter-scale, fine- to medium-grained graywacke turbidites that alternate with laminated gray-brown limestone beds as much as $30 \mathrm{~cm}$ thick, and thin-bedded chert and argillite. At the top of the section in Donkey Bay, below Permian limestone of the Pybus Formation, massive calcareous coarse-grained graywacke of the Cannery Formation contains Permian bryozoan, foraminiferal, echinoderm, and bivalve debris (figs. 2, $4 B$; loc. 21, fig. 2 and table 1) and angular intraformational clasts of green radiolarian chert, plagioclase, volcanic fragments, and bioclastic debris in a clayey to siliceous matrix containing secondary chlorite. Quartz clasts are rare or absent. On a triangular quartz-feldspar-lithics (QFL) diagram, 11 samples plot as lithic sandstones containing less than 20 volume percent quartz+chert (Q); 9 of these samples contain less than 10 volume percent Q (Loney, 1964). The lithic clasts are labeled as "chiefly volcanic" and the other lithic clasts are mainly carbonate (Loney, 1964). Well-rounded pebbles of gray and green chert, which are common in overlying limestone and dolostone of the Pybus Formation, support the interpretation that an erosional unconformity separates the Cannery and Pybus Formations (Loney, 1964; Lathram and others, 1965). Pervasive folding and faulting of the rocks on Admiralty Island preclude precise determination of unit thickness; a maximum thickness of "several hundred feet" for the Cannery Formation was inferred by Lathram and others (1965).

Figure 4. Rocks of the Cannery Formation dated by fossils in type area in Cannery Cove $(A)$ and Donkey Bay $(B)$ and similar dated rocks in Windfall Harbor $(C)$, southeastern Alaska, (figs. 1, 2). 


\section{Correlative Occurrences of the Cannery Formation on Admiralty Island}

Bryozoan debris similar to the early Permian bryozoan debris in Donkey Bay occurs in light-gray siliceous argillite, cherty phyllite, and calcareous graywacke at two fossil localities between Pybus and Gambier Bays (locs. 17, 19; fig. 2 and table 1). These two fossil localities extend the map area of the Cannery Formation to Gambier Bay (Loney, 1964). East of a fault at the head of Snug Cove in Gambier Bay, a 2-km-thick section of a more argillaceous facies of the Cannery Formation consists, from west to east, of (1) dark-gray meta-argillite containing blocks of limestone that yield Devonian corals (Loney, 1964) and Emsian through Famennian conodonts (A.G. Harris, written commun., 1982), (2) streaky green-gray sheared scaly argillite, (3) volcaniclastic rocks, (4) lenses of cataclastic
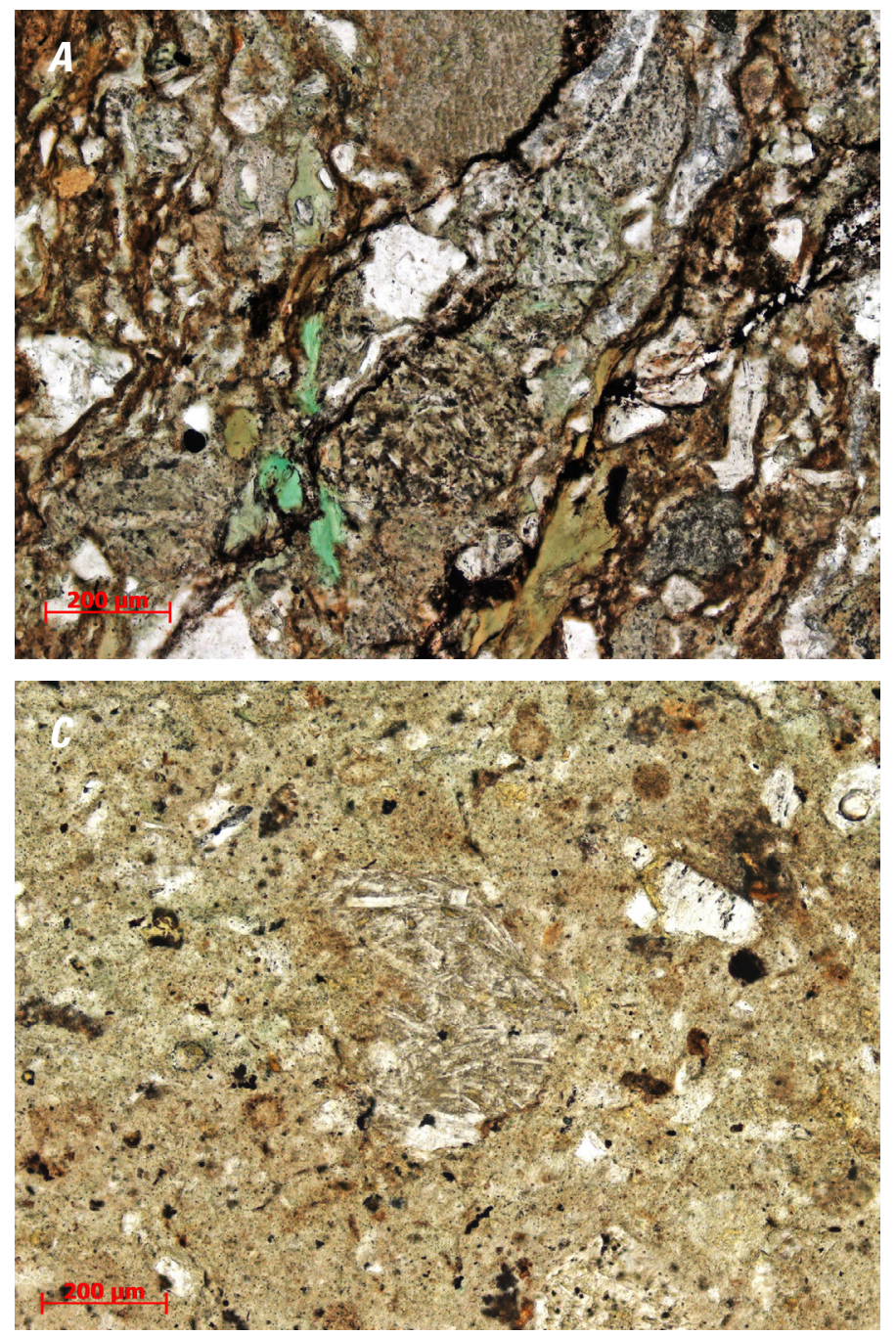

phyllonite, (5) turbidites consisting of argillite grading to chert or limestone, (6) pillow basalt and volcanic breccia, and (7) siliceous and carbonaceous radiolarian argillite (fig. 6) containing thin (millimeter to centimeter thick) flaser lenses of volcaniclastic siltstone, black chert, brown limestone, and lenses of calcareous bioclastic debris. A limestone lens in the black argillite contains early Late Mississippian (Meramecian) conodonts (loc. 54, fig. 2 and table 1; A.G. Harris, written commun., 1995). This section is overlain by fossiliferous limestone of the Pybus Formation southeast of Snug Cove, and by a basal limestone-matrix debris flow of the Late Triassic Hyd Group northeast of Snug Cove. The textures and rock types in the section at Snug Cove are similar to those typically found in accretionary complexes as defined by Hsu (1968) and Plafker and others (1977). Immobile-trace-element analysis of the volcanic rocks intercalated with argillite, chert, and graywacke of the Cannery Formation throughout the Admiralty Island map area (fig. 2) indicates a wide range
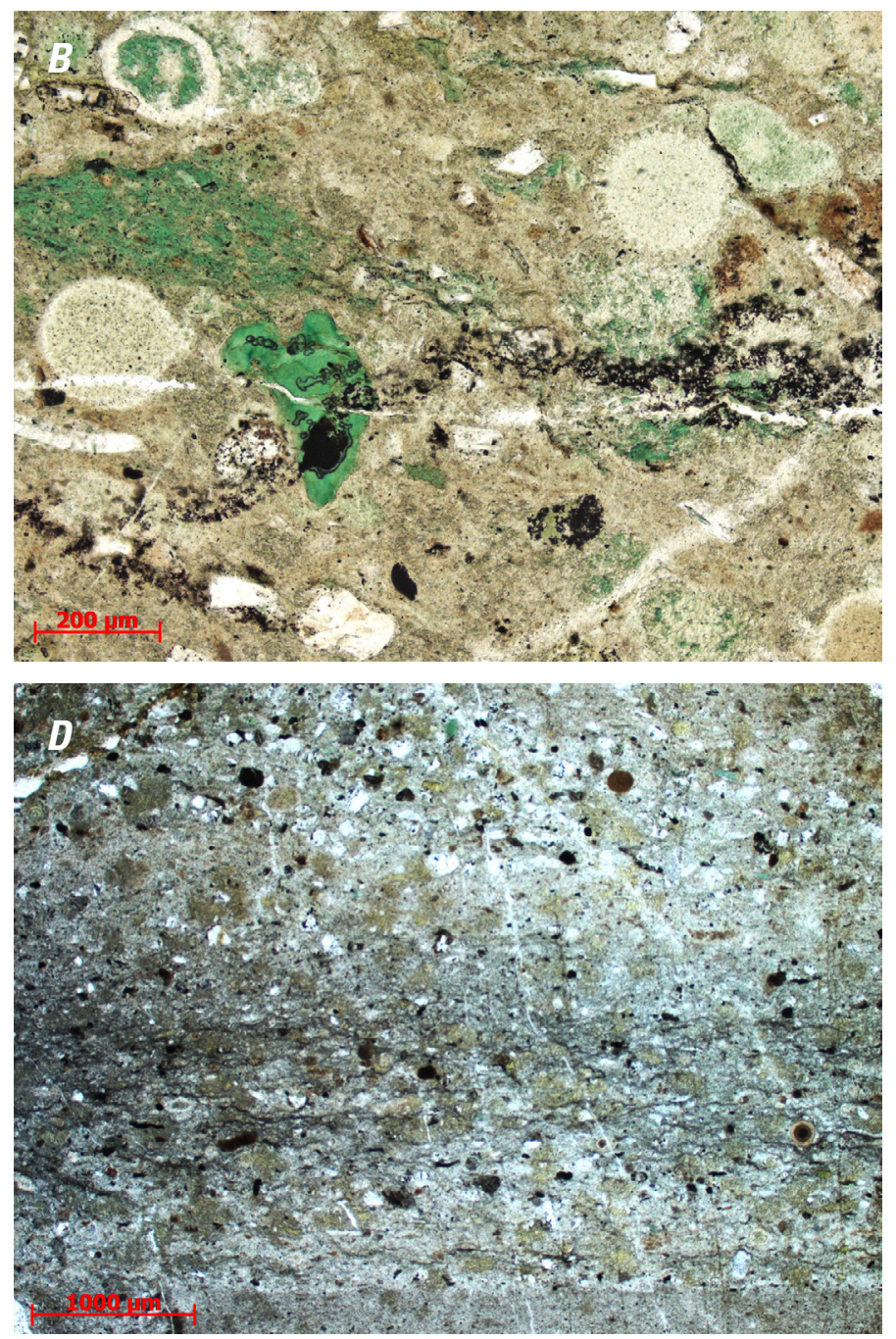

Figure 5. Photomicrographs of rocks of the Cannery Formation at Cannery Cove, southeastern Alaska (figs. 1,2). $A$, Volcanic fragments, echinoderm debris, feldspar, and chlorite in graywacke. Sample 94SK054A at 10x. B, Radiolarians, feldspar, and chlorite in siliceous siltstone. Sample 94SK058A at 10x. C, Volcanic fragment, feldspar crystals, and radiolarians in chert. Sample 94SK059A at 10x. $D$, Graywacke-chert turbidite bedding. Sample 94SK060A at 2.5x. Plane-polarized light. 
Table 1. Fossil ages reported for the Cannery Formation and equivalent rocks of southeastern Alaska.

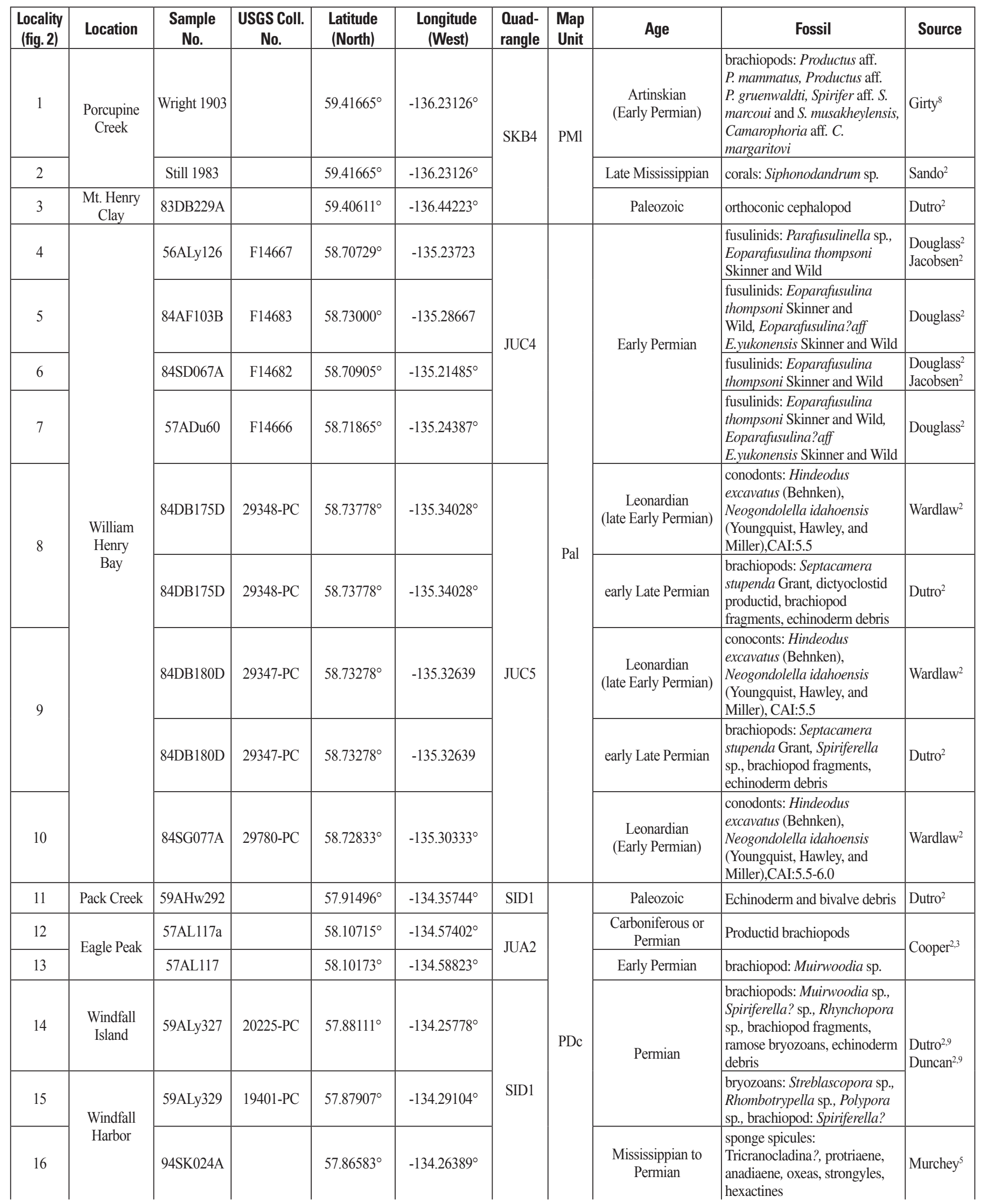


Table 1. Fossil ages reported for the Cannery Formation and equivalent rocks of southeastern Alaska.-Continued

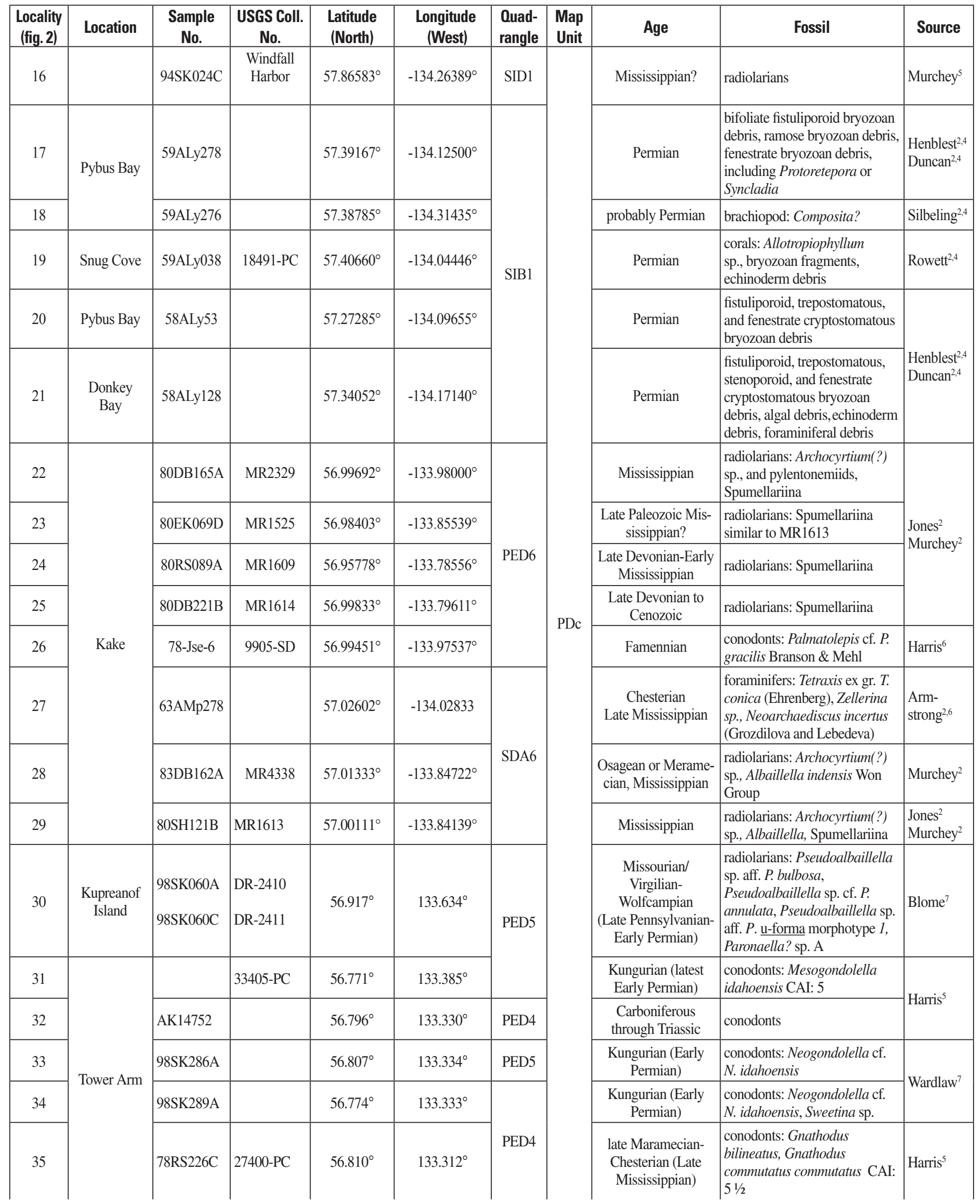


Table 1. Fossil ages reported for the Cannery Formation and equivalent rocks of southeastern Alaska.-Continued

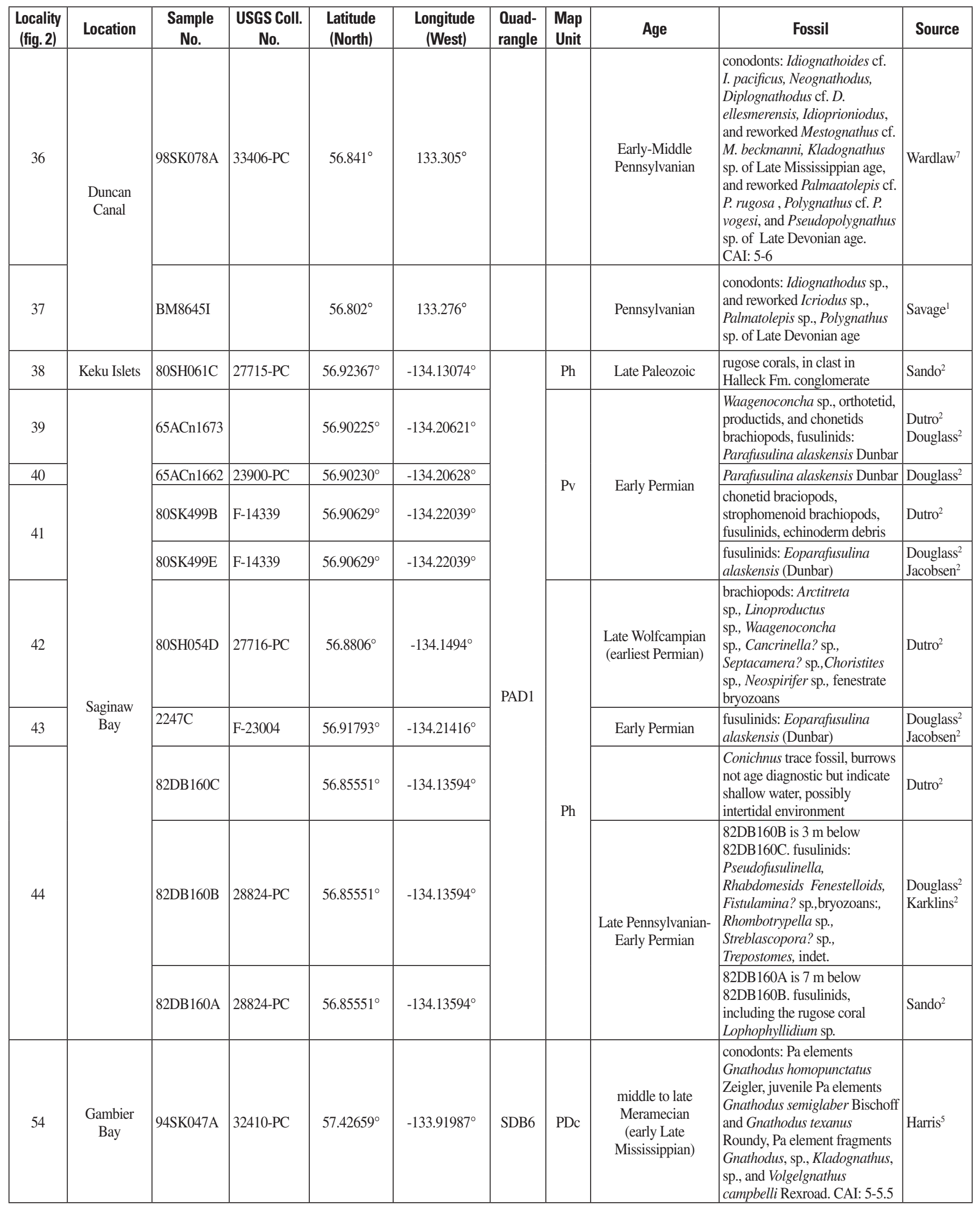


Table 1. Fossil ages reported for the Cannery Formation and equivalent rocks of southeastern Alaska.—Continued

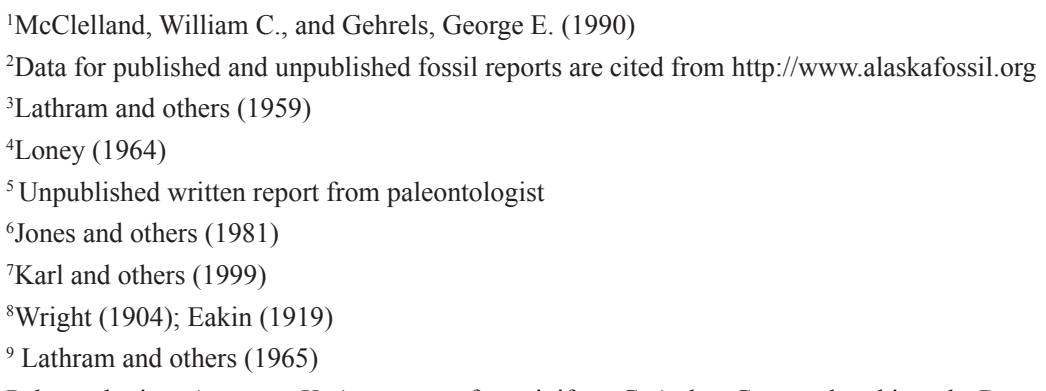

Paleontologists: Augustus K. Armstrong: foraminifers, G. Arthur Cooper: brachiopods, Raymond C. Douglass, Linda Jacobsen: fusulinids, Helen Duncan: corals and bryozoans, J. Thomas Dutro: megafossils, brachiopods, G.H. Girty: brachiopods, R.E. Grant, brachiopods, A.G. Harris: conodonts, L.G. Henbest: bryozoans, David L. Jones, Benita Murchey, Charles Blome: radiolarians, O.L. Karklins: bryozoans, Charles L. Rowett: Permian corals, W.J. Sando: corals, Norm Silberling: pelecypods, brachiopods, B.R. Wardlaw: conodonts.

CAI: color alteration index for conodonts.

Quadrangles: JU: Juneau, PA: Port Alexander, PE: Petersburg, SD: Sumdum, SI: Sitka, SK: Skagway.

Map Units as on figures. 1, 2.

Figure 6. Photomicrographs of argillite of the Cannery Formation at Snug Cove, southeastern Alaska (figs. 1, 2). A, Bedding and cleavage. Sample 94SK046A at 10x in plane-polarized light. $B$, Carbonaceous and siliceous composition. Sample 94SK046A at 10x under crossed nicols.

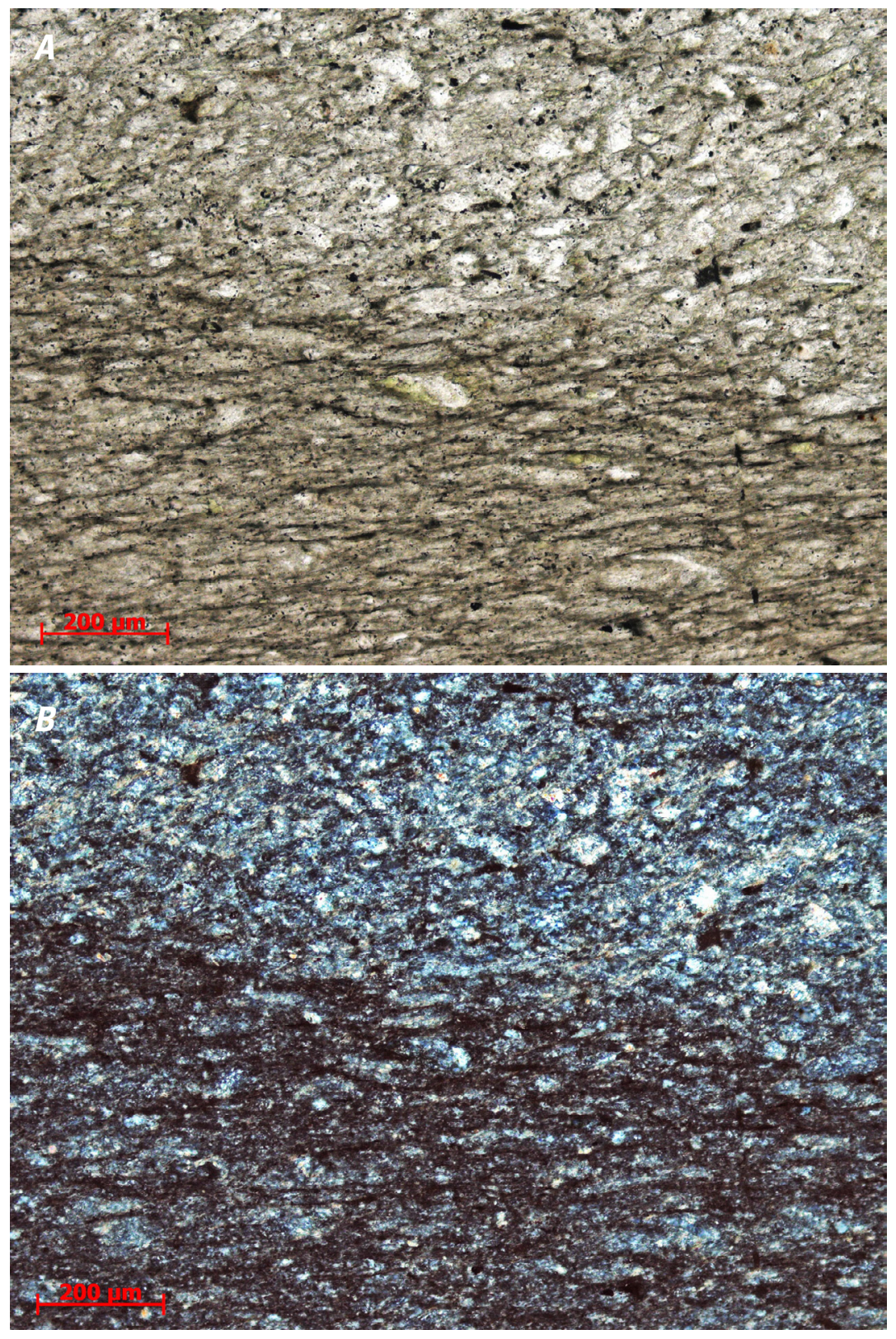


Table 2. Fossil ages reported for the Pybus Formation and equivalent rocks of southeastern Alaska.

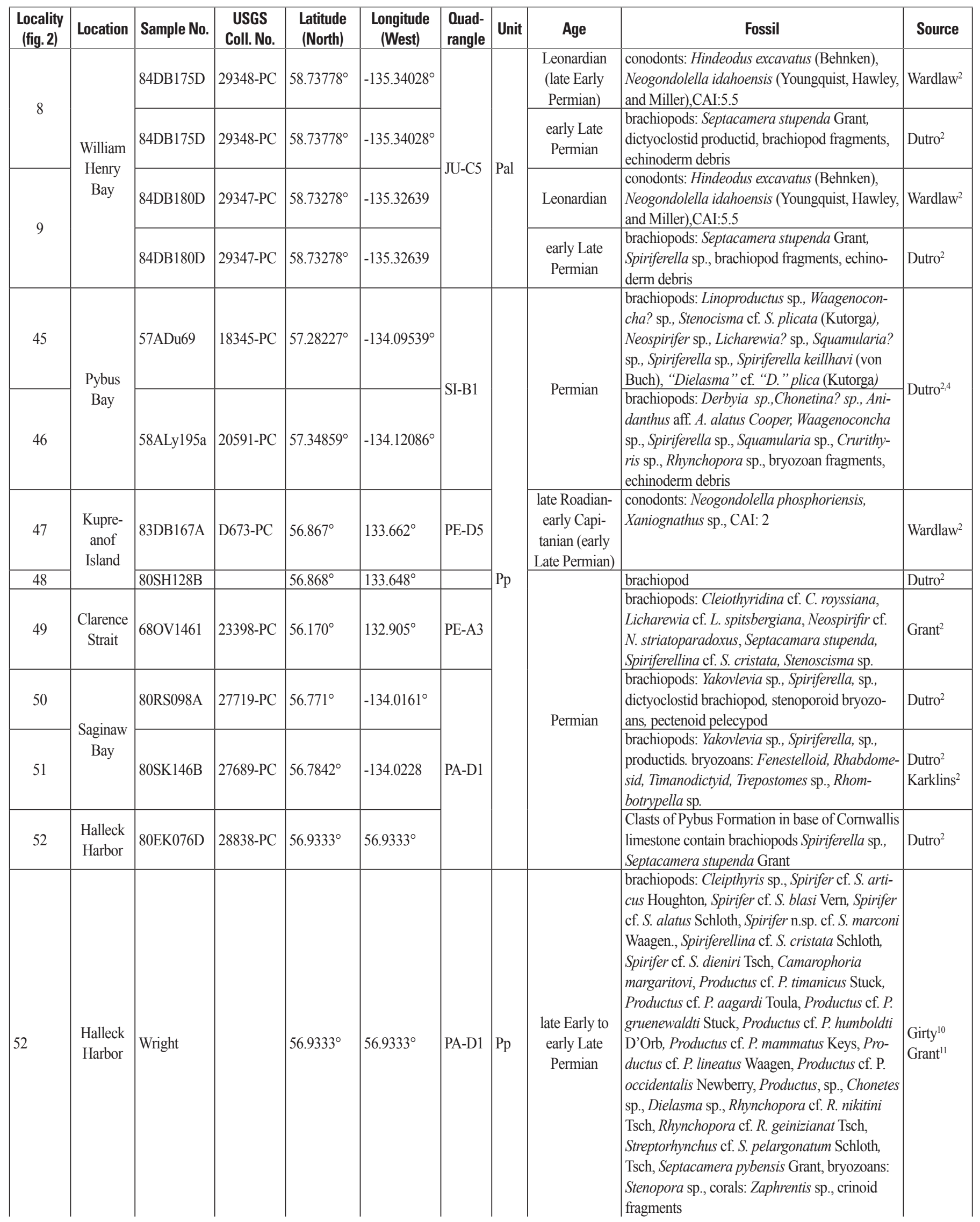


Table 2. Fossil ages reported for the Pybus Formation and equivalent rocks of southeastern Alaska.-Continued

\begin{tabular}{|c|c|c|c|c|c|c|c|c|c|c|}
\hline $\begin{array}{c}\text { Locality } \\
\text { (fig. 2) }\end{array}$ & Location & Sample No. & $\begin{array}{l}\text { USGS } \\
\text { Coll. No. }\end{array}$ & $\begin{array}{l}\text { Latitude } \\
\text { (North) }\end{array}$ & $\begin{array}{l}\text { Longitude } \\
\text { (West) }\end{array}$ & $\begin{array}{l}\text { Quad- } \\
\text { rangle }\end{array}$ & Unit & Age & Fossil & Source \\
\hline 53 & $\begin{array}{c}\text { Suemez } \\
\text { Island }\end{array}$ & $15 \mathrm{ACh} 240$ & & $55.26531^{\circ}$ & $-133.2325^{\circ}$ & CR-B4 & $\mathrm{Pl}$ & Permian & $\begin{array}{l}\text { brachiopods: Cleiothyridina? sp., Spirifer cf. S. } \\
\text { tastubensis, Spirifer cf. S. interplicatus, Spirifer } \\
\text { cf. S.schellwieni, Spirifer, sp., Griffithides, sp., } \\
\text { Camarophoria cf. C. margaritovi, Productus } \\
\text { cf. P. humboldti, Productus cf. P. mammatus, } \\
\text { Productus, sp., Chonetes cf. C. verneuilianus, } \\
\text { Dielasma cf. D. bovidens, Dielasma sp., } \\
\text { Globiella? sp., Septacamara stupenda, } \\
\text { Spiriferellina cf. S. cristata, Stenoscisma sp., } \\
\text { bryozoans: Fistulipora sp., Stenopora sp., } \\
\text { Leioclema sp., corals: Zaphrentis sp. }\end{array}$ & $\begin{array}{l}\text { Girty }^{12} \\
\text { Grant }^{2}\end{array}$ \\
\hline
\end{tabular}

Quadrangles: CR: Craig, JU: Juneau, PA: Port Alexander, PE: Petersburg, SI: Sitka.

Map Units as on figures. 1,2.

CAI: conodont alteration index

Paleontologists - J.T. Dutro: brachiopods, R.E. Grant: brachiopods, O.L. Karklins: bryozoans, B.R. Wardlaw: conodonts.

Footnote numbers as on table 1.

${ }^{2}$ Data for published and unpublished fossil reports are cited from Alaska Paleontologic Database, http://www.alaskafossil.org

${ }^{4}$ Loney (1964)

${ }^{10}$ Wright and Wright (1908)

${ }^{11}$ Grant (1971)

${ }^{12}$ Buddington and Chapin (1929)

of chemical compositions. Samples of fresh, unaltered basalt analyzed from volcanic rocks of the Cannery Formation on Admiralty Island plot in volcanic-arc, midocean-ridge, and ocean-island fields on discriminant diagrams (fig. 8). Similar variable compositions of basalt, which commonly occur in accretionary complexes at plate margins where subducting oceanic-plate rocks are structurally interleaved with trench, slope, and other forearc deposits, have been documented, for example, in the Chugach terrane (Hill, 1979; Karl, 1982; Nelson and Blome, 1991).

The rocks at Windfall Harbor were included in the Cannery Formation by Lathram and others (1965). Permian bryozoan debris was recovered from interbedded graywacke and limestone in Windfall Harbor (locs. 14, 15, fig. 2 and table 1). Brownish-gray limestone in dark-gray slaty argillite on Windfall Island (figs. 2, $9 A$; loc. 14, table 1) contains the Permian brachiopod Muirwoodia (Lathram and others, 1965; see Alaska Paleontologic Database, http://www.alaskafossil.org). On the east shore of Windfall Harbor, fine-grained graywacke grades to chert in turbidite beds similar to those at Cannery Cove (fig. 4C). Radiolarians are distributed throughout both graywacke and chert of individual turbidite beds, are not considered to be reworked, and yielded Mississippian(?) through Mississippian-Permian ages (loc. 16, fig. 2 and table 1; B.L. Murchey, written commun., 1997).

The brachiopod Muirwoodia was also recovered from graywacke and dark-gray slaty argillite in the middle of a section on the west shoulder of Eagle Peak on northern Admiralty Island (loc. 13, fig. 2 and table 1; Helen Duncan, written commun., 1957; Lathram and others, 1958, 1959, 1960). These rocks were included in the Cannery Formation by Lathram and others (1965). The section at Eagle Peak consists of pillow basalt and radiolarian ribbon chert, overlain by graywackeargillite turbidites, grading upward to sooty carbonaceous slate-phyllite that contains thin beds of gray-brown bioclastic limestone. This sooty slate-phyllite is indistinguishable from overlying Late Triassic Halobia-bearing sooty slate of the Hyd Group unless fossils are present. The oldest fossils in the Hyd Group are Middle Triassic, and the unit is commonly floored by a basal breccia. Limestone of the Pybus Formation is absent in the Greens Creek area (fig. 2). Extremely slow deposition, a disconformity, or a fault is inferred for the Cannery Formation-Hyd Group contact in the vicinity of Eagle Peak and Greens Creek. Only structural contacts have been observed between the Cannery Formation and greenschistfacies rocks with Permian metamorphic-mineral ages on Admiralty Island.

\section{Distinguishing Features of the Cannery Formation in the Type Area}

Several features distinguish the Cannery Formation, as originally defined on Admiralty Island, from other units in the Alexander terrane. Sandstone of the Cannery Formation is distinguished from other sandstone on Admiralty Island by a clast population dominated by volcanic fragments, calcareous bioclastic debris, euhedral feldspar, chert, black radiolarian cherty argillite with quartz veins, little or no quartz, and a siliceous matrix. The Ordovician through Devonian Hood Bay 

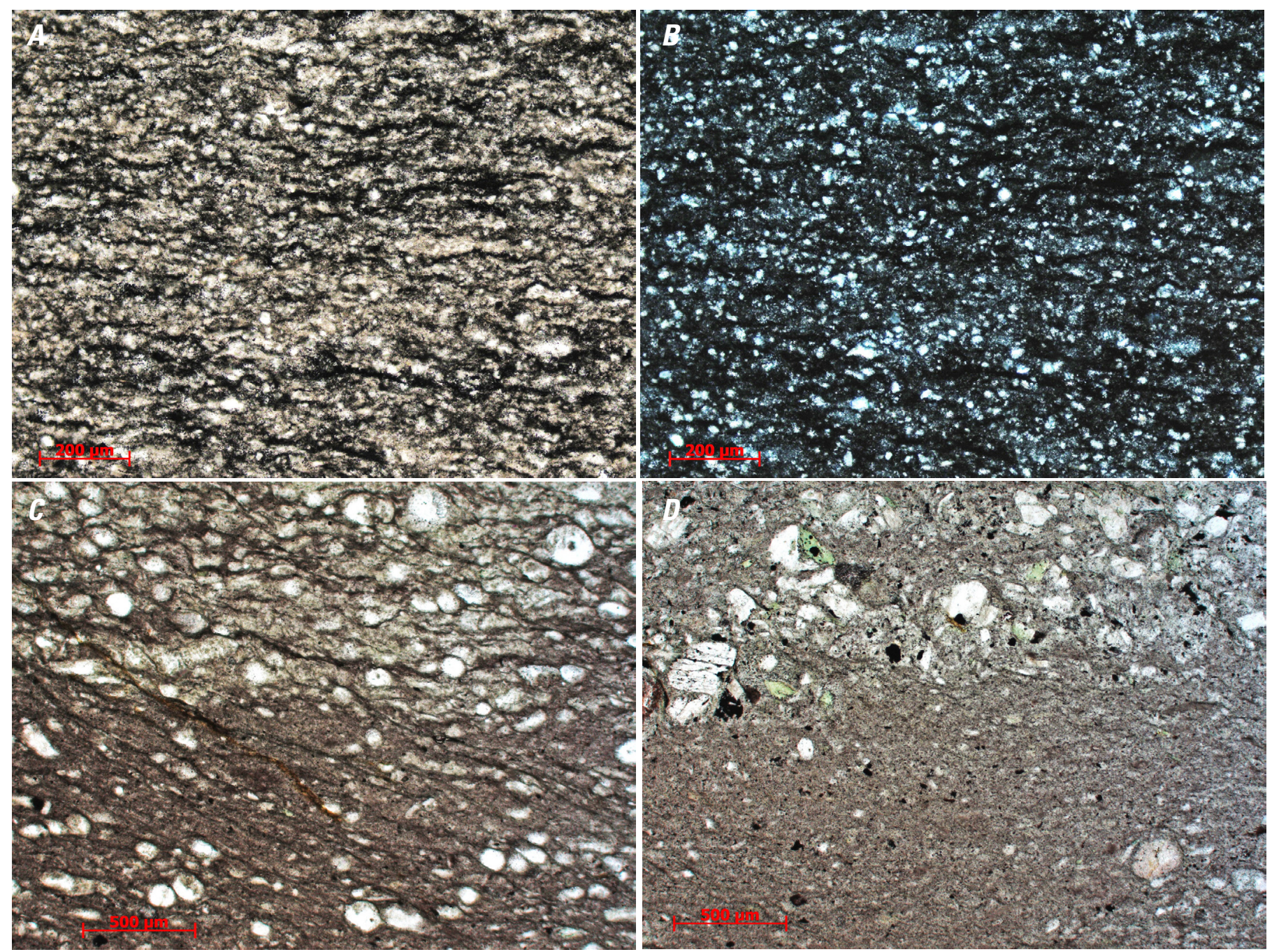

Figure 7. Photomicrographs of rocks of the Cannery Formation at Windfall Harbor, southeastern Alaska (figs. 1, 2). $A$, Cleavage in siliceous argillite. Sample 94SK022A at 10x under plane-polarized light. B, Carbonaceous and siliceous composition. Sample 94SK022A at $10 x$ under crossed nicols. $C$, Bedding in radiolarian chert turbidites. Dated sample 94SK024C at 5x under plane-polarized light. D, Base of sandstone layer in turbidites, showing volcanic fragments, feldspar, and glauconite. Sample 94SK024C at 5x under plane-polarized light.

Formation on Admiralty Island is distinguished from the Cannery Formation by its content of highly carbonaceous black radiolarian chert, graptolitic argillite, graywacke dominated by clasts of chert and argillite, massive mafic volcanic rocks, and 10- to 30-m thick sections of thinly laminated dark-gray fetid limestone. Rocks of the Hood Bay Formation are more deformed than those of the Cannery Formation and have a pervasive fabric with networks of quartz veinlets that are absent in the Cannery Formation. Clasts of veined, sheared black radiolarian chert and argillite identical to rocks of the Hood Bay Formation that are recognized in sandstone of the Cannery Formation on southern Admiralty Island indicate a stratigraphic relation between the two units. The Cannery Formation is distinguished from the Halleck Formation by the calcareous composition of all sedimentary rocks of the Halleck Formation, in contrast to the siliceous composition of sedimentary rocks of the Cannery Formation. Siltstone and chert of the Cannery Formation are distinguished from those of other clastic units in the Alexander terrane by the combined presence of undeformed radiolarians, disseminated angular feldspar clasts that are present even in ribbon chert, and a notable rarity of quartz grains.

\section{Rocks Assigned to the Cannery Formation on Kupreanof and Zarembo Islands}

Bedded black, red, and teal-green radiolarian chert near Kake on Kupreanof Island (figs. 2, 3, 10A, 11C, 12) was lithologically correlated with the Cannery Formation by 
Muffler (1967). The section at Kake is almost continuously exposed in roadcuts and along the northwest-trending shoreline of Keku Strait. At the southeast and northwest ends of Muffler's (1967) mapped Cannery Formation, the chert is overlain (contact not exposed) by fossiliferous late early and early late Permian limestone of the Pybus Formation, which is overlain by Triassic limestone and basalt of the Hyd Group. The village of Kake, at the mouth of Gunnuck Creek, is about midway between outcrops of limestone of the Pybus Formation; the rocks at Kake apparently represent the base of
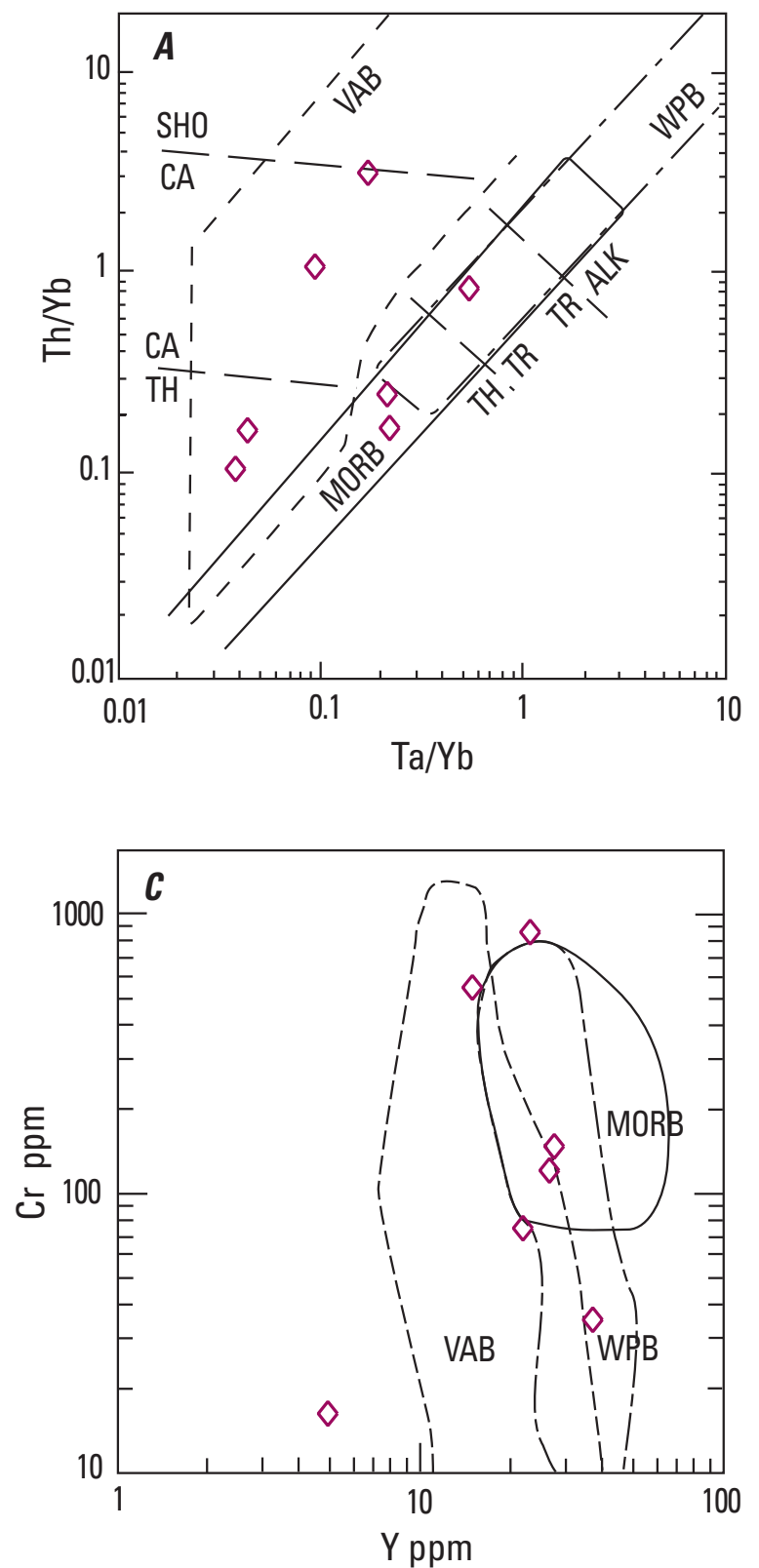

a synclinal section exposed along the northeast shore of Keku Strait. A limestone lens in chert near Kake yielded Paleozoic radiolarians and Late Devonian (Famennian) conodonts (loc. 26, fig. 2 and table 1, fig. 10A; Jones and others, 1981). Late Mississippian (Chesterian) foraminifers were recovered about $5 \mathrm{~km}$ northwest of the Devonian locality (loc. 27, fig. 2 and table 1; Jones and others, 1981). The lowest part of the section at Kake consists of black and teal-green ribbon chert and includes rare silty chert turbidite beds but not graywacke or graywacke-chert turbidites. This part of the chert section
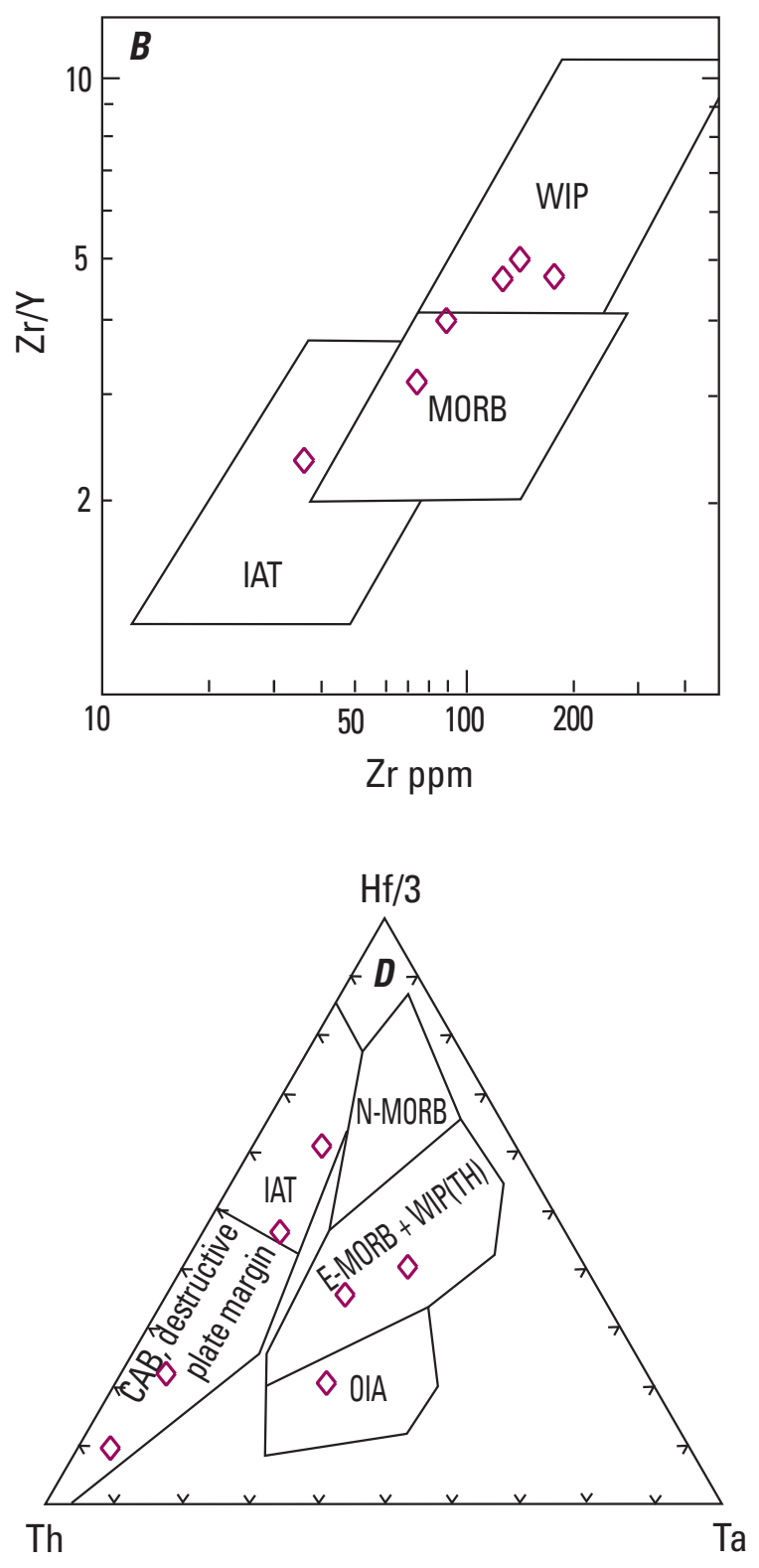

Figure 8. Compositional diagrams showing immobile-trace-element chemistry of volcanic rocks associated with the Cannery Formation on Admiralty Island, southeastern Alaska (figs. 1, 2). A, Th/Yb-Ta/Yb diagram of Pearce (1982). B, Zr/Y-Zr diagram of Pearce and Norry. (1979). Element contents are plotted in parts per million. C, Cr-Y diagram of Pearce (1982). Element content $+s$ are plotted in parts per million. $D$, Hf/3-Th-Ta diagram of Wood (1980). 
at Kake is overlain by graywacke-argillite turbidites and a basalt flow. Late Early or early Late Mississippian (Osagean or Meramecian) radiolarians (loc. 28, fig. 2 and table 1; B.L. Murchey, written commun., 1981) were recovered from bedded chert near its contact with the Pybus Formation on northwestern Kupreanof Island. Mississippian radiolarians (figs. 2, 9B; locs. 23, 28, 29, fig. 2 and table 1; D.L. Jones and B.L. Murchey, written commun., 1981) were recovered from green bedded chert beneath the Pybus Formation in the upper reaches of Gunnuk Creek (see Alaska Paleontologic Database, http://www.alaskafossil.org/). Higher in the section, 30- to 100 -cm-thick beds of stylolitic chert contain abundant sponge spicules and radiolarians of Late Pennsylvanian and early Permian age (figs. 2, 9C, $10 B-D$; loc. 30, fig. 2 and table 1; Karl and others, 1999), and include a clay-rich chertmatrix-supported debris flow that contains angular pebbles to boulders of gray and green chert. The chert at this locality is dominantly spiculitic and contains disseminated angular clasts of feldspar and spumellarian radiolarians, similar to the chert in Cannery Cove and Windfall Harbor. Stylolitic partings in the bedded chert suggest dissolution of carbonate and replacement by chert. The clasts of gray and green chert are inferred to be intraformational and may signal local uplift analogous to the uplift that contributed chert pebbles to the age-correlative early Permian Halleck Formation on Kuiu Island (Jones and others, 1981; Brew and others, 1984).

The rocks on Kupreanof Island along Towers Arm in Duncan Canal contain Permian fossils (Karl and others, 1999) and include green and gray siliceous phyllitic argillite, calcareous volcanic wacke, black carbonaceous slate, chert, pillow basalt, and lenses of brown-weathering gray limestone that contain early Permian conodonts (locs. 31-34, fig. 2 and table 1; Karl and others, 1999). These rocks, which are apparently coextensive with the chert and graywacke to the northwest near Kake, represent a depositional facies change from chert-graywacke to argillite-graywacke, analogous to the Permian facies change between Cannery Cove and Gambier Bay on Admiralty Island. The early Permian conodonts from Towers Arm indicate that these rocks predate the limestone of the Pybus Formation mapped on western Kupreanof Island. The rocks have
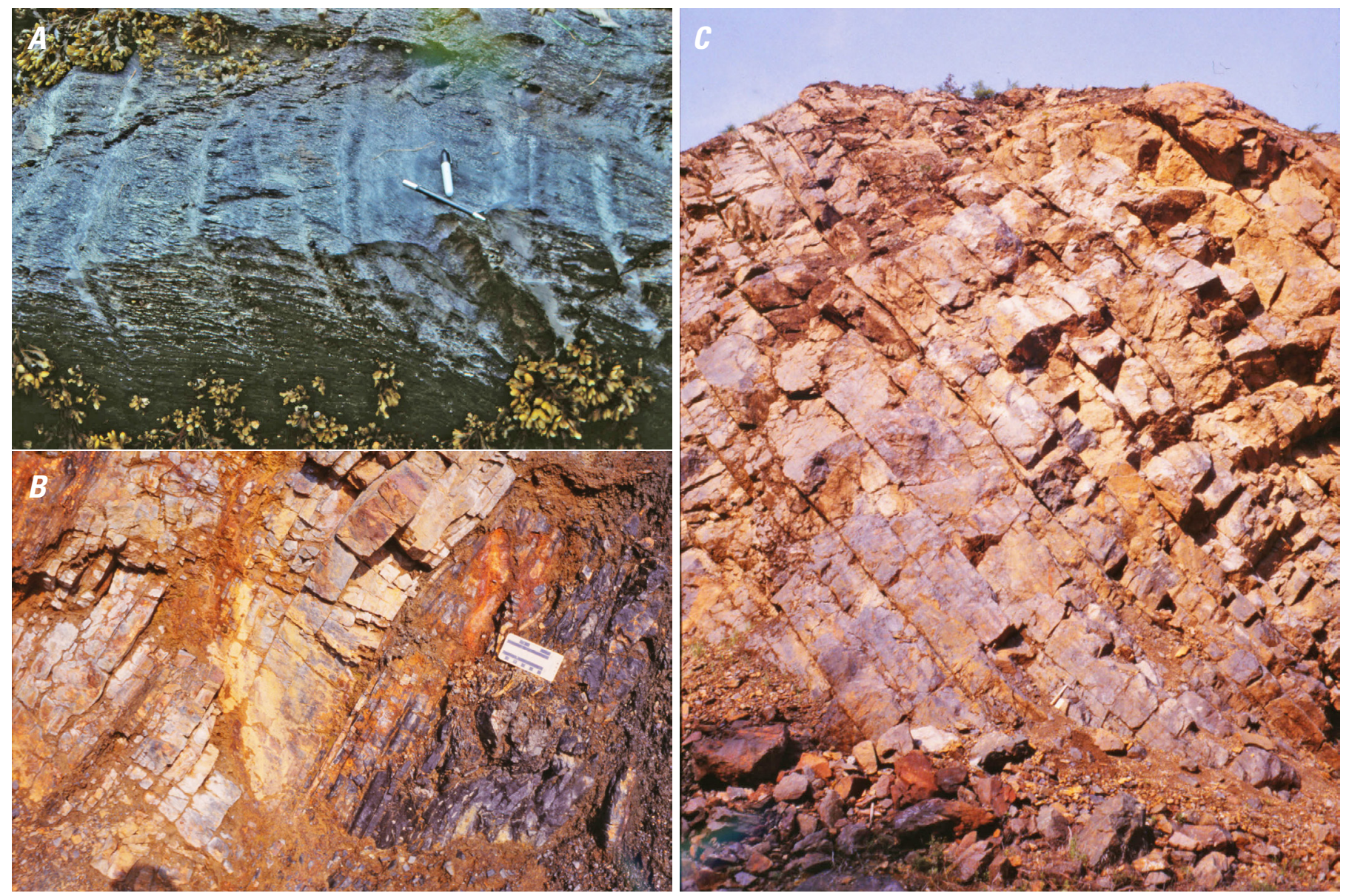

Figure 9. Rocks of the Cannery Formation on Windfall and Kupreanof Islands, southeastern Alaska (figs. 1, 2). $A$, Early Permian limestone on Windfall Island. B, Bedded chert on Kupreanof Island. C, Bedded gray chert containing Mississippian and Pennsylvanian fossils on Kupreanof Island. 
a pervasive cataclastic shear fabric with a streaky texture of mixed argillaceous and volcanic material that locally includes web structures, debris flows, blocks in matrix, and scaly argillite textures which are commonly ascribed to accretionary complexes (fig. 11A; Hsu, 1968; Cowan, 1982; Byrne, 1984). The rocks at Towers Arm resemble those in eastern Snug Cove on Admiralty Island and are nearly contemporaneous with rocks of both the early Permian Halleck Formation (figs. 2, 3) and the upper part of the Cannery Formation; their age, siliceous argillitic composition, chaotic fabric, and association with bedded chert on Kupreanof Island led Karl and others (1999) to assign them to the Cannery Formation. Similar deformed cherty argillite and volcaniclastic rocks that underlie Mesozoic rocks on Zarembo Island (figs. 2, 11B) are assigned to the Cannery Formation (Karl and others, 1999).
Greenschist-facies metamorphic rocks similar to those on Admiralty Island (Karl and others, 1999) that are exposed on northern Kupreanof Island are in fault contact with lower-grade rocks mapped as the Cannery Formation. Although the lower-grade rocks are extensively folded and faulted, they appear to grade from Devonian bedded chert at the southwest inferred base (near Kake) of the section to early Permian argillite at the northeast inferred top (near Duncan Canal) of the section. The true thickness of this depositional sequence is indeterminate. Whether the Devonian black chert at the base of the section is in continuous depositional contact with gray-red-green Mississippian and Permian chert, argillite, and graywacke that are more typical of the Cannery Formation at its type locality is unclear.
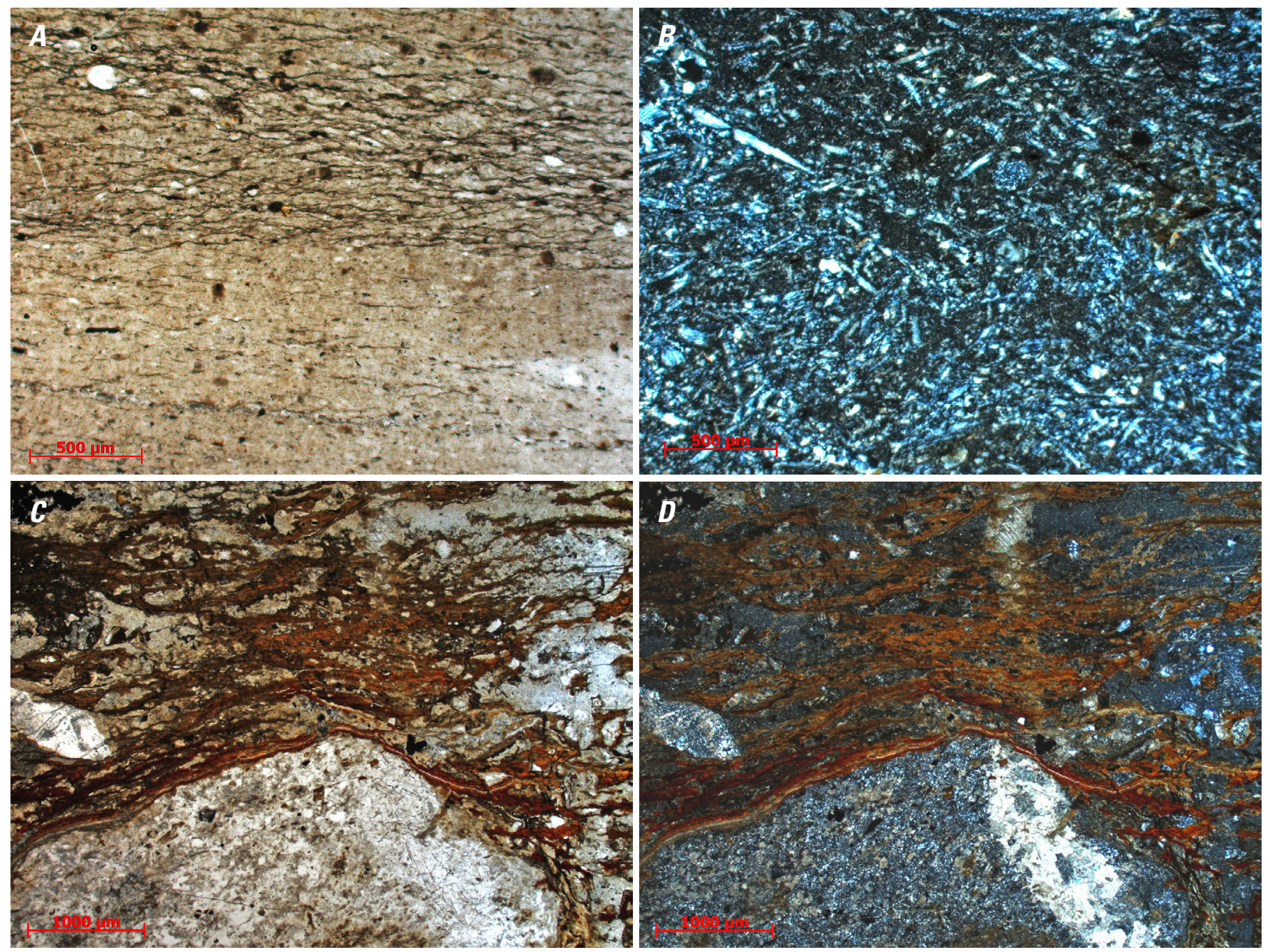

Figure 10. Photomicrographs of rocks of the Cannery Formation on Kupreanof Island, southeastern Alaska (figs. 1, 2). A, Late Devonian radiolarian chert at Kake. Sample 03SK019D at $5 x$ under plane-polarized light. $B$, Sponge spicules and radiolarians. Dated chert sample 98SK060A at 5x under crossed nicols. C, Matrix-supported conglomerate, showing fabric and feldspar clasts in matrix of chert and hematitic clay. Sample 98SK060E at 2.5x under plane-polarized light. $D$, Matrix-supported conglomerate showing recrystallized chert clast and matrix of chert and hematitic clay. Sample 98SK060E at 2.5x under crossed nicols. 


\section{Devonian Chert-Bearing Lithostratigraphic Units in the Alexander Terrane}

The Alexander terrane contains numerous Devonian stratigraphic units. The following discussion is limited to Devonian units that include chert and rocks lithologically similar to those assigned to the Cannery Formation. The purpose of this discussion is to evaluate whether the Devonian chert at Kake should be assigned to the Cannery Formation or more appropriately to some other unit. The Devonian chertbearing units in southeastern Alaska form three discrete belts: the northern two belts, at Hawk Inlet and Kake, flank mafic metavolcanic rocks and massive Devonian metalimestone (part of the Paleozoic metamorphic rocks in fig. 2, and the Devonian mafic volcanic rocks in fig. 12). The southern belt overlies the northeast side of Late Devonian volcanic rocks and red beds in Saginaw Bay (fig. 12).

\section{Devonian Chert at Kake}

In the absence of fossil ages, the bedded black, red, and teal-green radiolarian chert exposed at Kake on Kupreanof Island (figs. 3, 12) was lithologically correlated with the Cannery Formation by Muffler (1967). The chert at Kake forms a section more than $100 \mathrm{~m}$ thick, but its true unit thickness is unknown. The section consists predominantly of chert in beds that range from 4 to $30 \mathrm{~cm}$ and average $6 \mathrm{~cm}$ in thickness, have pinch-and-swell structures, argillaceous partings, and contain rare intercalations of limestone, calcareous siltstone, and very fine-grained volcaniclastic sandstone turbidites. The chert beds include soft-sediment slump folds with pods of argillite in fold cores and thickened chert beds at fold noses. Sedimentary slump structures and starved ripple beds suggest quiet-water deposition on a slope or in a basin with low sediment input. The chert also contains sparse quartz veins (fig. 11C). The siltstone is tan and contains clasts of argillite. The basal chert section at Kake is overlain to the northwest by volcaniclastic turbidites, which are in turn overlain by chert that includes a limestone lens containing Late Devonian (Famennian) conodonts (loc. 26, fig. 2 and table 1; Jones and others, 1981). This chert is overlain by bedded chert that contains Mississippian radiolarians (loc. 22, fig. 2 and table 1; see Jones and Murchey, 1981, in Alaska Paleontologic Database, http://www.alaskafossil.org/). The Mississippian chert is overlain by chert, pillow basalt, and gray and green chert, argillite, and fine-grained volcaniclastic rocks.

Figure 11. Deformed slaty argillite of the Cannery Formation in southeastern Alaska (figs. 1, 2). A, Argillite with lenses and blocks of tuff and limestone from Towers Arm, Kupreanof Island. $B$, Argillite, chert, and tuff from Zarembo Island. $C$, Bedded black chert with quartz veins at Kake.
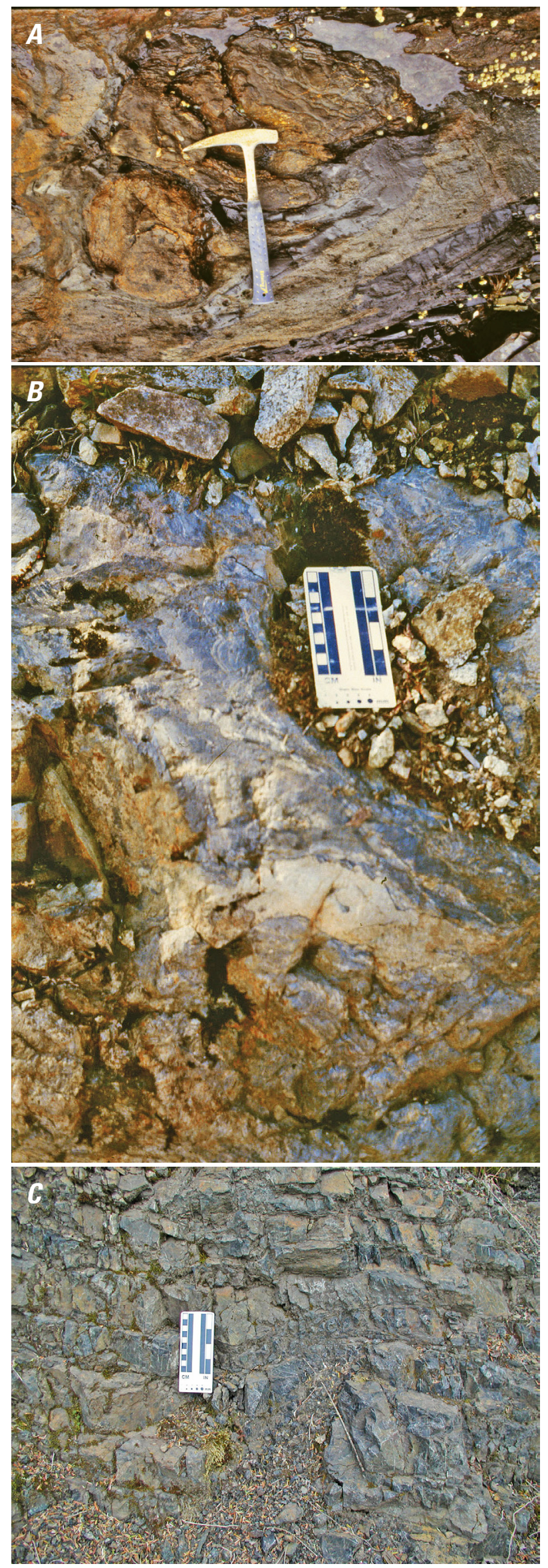


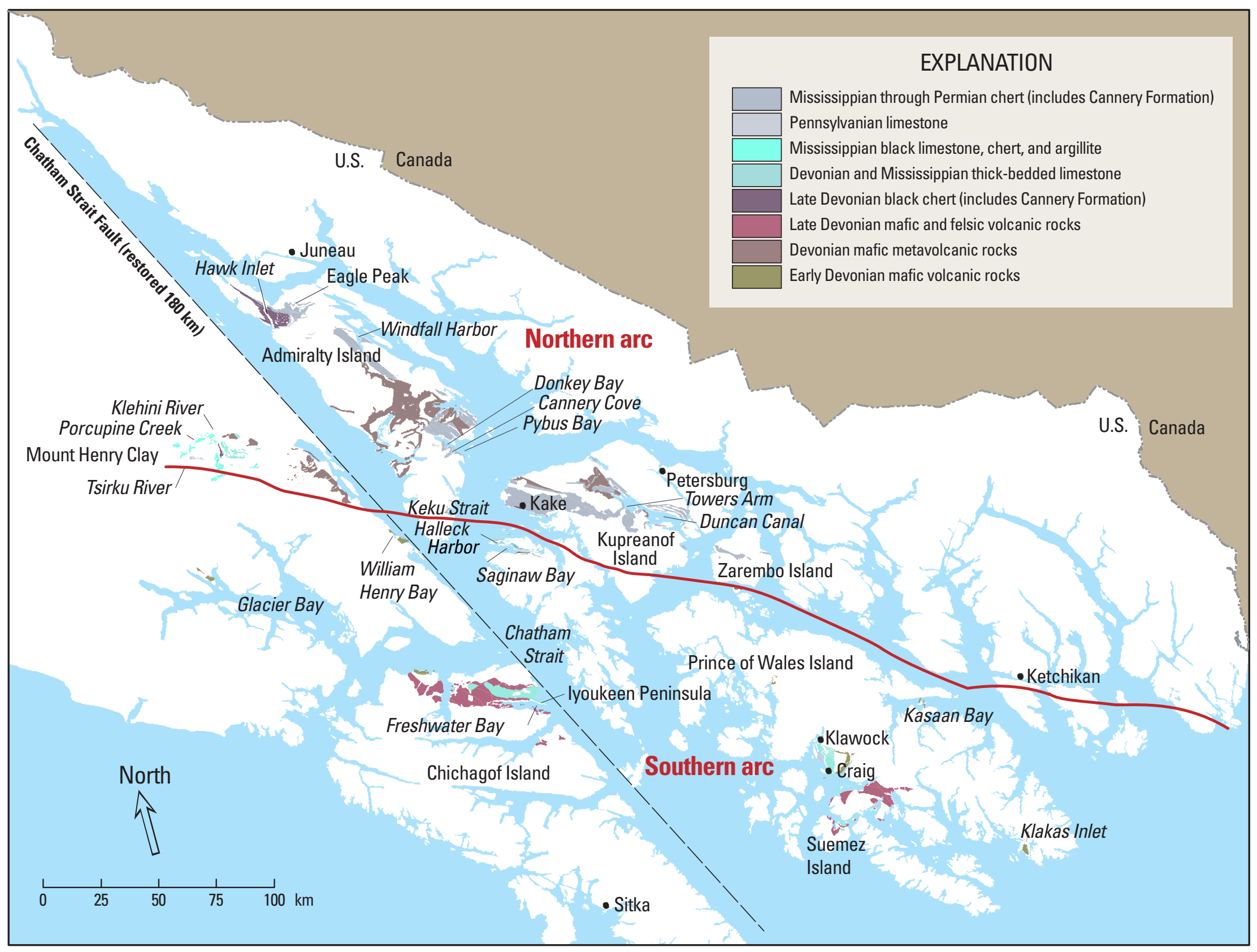

Figure 12. Southeastern Alaska, showing the distribution of Late Devonian, Early Mississippian, and Late Mississippian black chert and limestone in the Alexander terrane. Rocks south and west of the Denali-Chatham Strait Fault have been restored $180 \mathrm{~km}$ to better reflect Permian paleogeography. 


\section{Saginaw Bay Formation}

The Saginaw Bay Formation was defined as a Carboniferous unit consisting of a lower volcanic member, a black chert member, a chert and limestone member, and an uppermost silty limestone member depositionally overlain by Permian siltstone, limestone, and basalt of the Halleck Formation (Muffler, 1967). At the head of Saginaw Bay on Kuiu Island (fig. 2), designated as the type locality for the Saginaw Bay Formation (Muffler, 1967), tuffaceous limestone of Muffler's lower volcanic member later yielded conodonts of Middle Ordovician through Devonian age. The black chert member consists of thin-bedded black chert and dense, thinly laminated dark-gray limestone (fig. 2, 3; Muffler, 1967). One limestone lens in chert at the head of Saginaw Bay contains the late Eifelian conodont Tortodus kockelianus kockelianus (Bischoff and Ziegler), pb elements of Oulodus sp., and a pa element of Polygnathus aff. P. pseudofoliatus Wittekindt, and another lens yielded late Emsian through early Frasnian Polygnathus linguiformis linguiformis (see A.G. Harris, 1983, in Alaska Paleontologic Database, http://www.alaskafossil.org/). The chert contains Late Devonian or younger entactiniid radiolarians (D.L. Jones and B.L. Murchey, 1981, in Alaska Paleontologic Database, http://www.alaskafossil.org/). These fossils together indicate a Late Devonian age for the black chert member of the Saginaw Bay Formation. On the basis of these fossil reports, Brew and others (1984) extended the age of the Saginaw Bay Formation to Devonian through Pennsylvanian. The tan limestone and chert member that overlies the black Devonian chert is undated. Above the tan limestone and chert member, the chert and limestone member of the Saginaw Bay Formation contains early Middle Pennsylvanian foraminifers, brachiopods, gastropods, and bryozoans (Muffler, 1967; Dutro and Douglass, 1961; see Alaska Paleontologic Database, http://www.alaskafossil.org/). The uppermost member of the Saginaw Bay Formation, the silty limestone member, contains the Late Pennsylvanian and early Permian brachiopod, Linoproductus (see J.T. Dutro, 1983, in Alaska Paleontologic Database, http://www.alaskafossil.org/). This section differs from the section at Kake in that the Devonian chert at Saginaw Bay is interbedded with limestone and overlain by cherty and silty limestone rather than the basalt, volcaniclastic turbidites, and bedded chert that overlie the Devonian chert at Kake.

\section{Chert of Hawk Inlet}

Black-and-gray bedded metachert associated with greenand-gray siliceous phyllite and mafic metavolcanic semischist includes lenses of metalimestone containing Famennian conodonts (A.G. Harris, written commun., 2001) at two localities north of Hawk Inlet on Admiralty Island (Late Devonian black chert, fig. 12). This black metachert on Admiralty Island was assigned to the Retreat Group by Lathram and others (1965) and later assigned by Brew and Ford (1985) to their map unit Mzps, which corresponds exactly in area to the unit formerly mapped as the Retreat Group. The Hawk Inlet metachert was never assigned to the Cannery Formation although it is mapped near rocks assigned to the Cannery Formation (fig. 2). Because the Hawk Inlet metachert section contains Late Devonian conodonts, it can neither be included in the Retreat Group, which is intruded by Neoproterozoic plutons (Karl and others, 2006), nor can it be assigned to a Mesozoic unit. The east boundary of the Devonian metachert at Hawk Inlet is faulted against sooty black argillite that lies along strike from the early Permian Muirwoodia locality in sooty argillite on the west flank of Eagle Peak (loc. 13, fig. 2 and table 1). The chert in Hawk Inlet is metamorphosed, folded, and deformed, with folded segregation layering that records three deformation events, and its stratigraphic relations are unclear. Because the metachert is nearly identical in age and protolith to the black chert at Kake, it adds support for a Late Devonian lithofacies that is best documented if the rocks are mapped as discrete units. Undated, deformed, bedded black chert also occurs in the Hood Bay Formation west of Pybus Bay, but it is associated with argillite containing Ordovician graptolites (Carter, 1977), limestone containing Silurian-Devonian conodonts, and mafic volcanic and volcaniclastic rocks. The chert in Hawk Inlet and the Hood Bay Formation differ in degree of metamorphism and deformation from the chert at Kake and Saginaw Bay. Although no metamorphic minerals in the chert at Hawk Inlet or Hood Bay have been dated, these rocks are adjacent to rocks on northern Admiralty Island that have Devonian protoliths and have yielded Permian metamorphicmineral cooling ages (see fig. 15; table 3 ).

\section{Mississippian Chert-Bearing Lithostratigraphic Units in the Alexander Terrane}

Mississippian chert-bearing lithostratigraphic units are widespread in the Alexander terrane. They include rocks along the Klehini River northwest of Haines, the Iyoukeen Formation on Chichagof Island, the Saginaw Bay Formation on Kuiu Island, and the Peratrovich Formation on southern Prince of Wales Island (figs. 2, 3, 12). The Mississippian rocks in these units are described here to compare Mississippian chert of the Cannery Formation with other possible correlative chert-bearing units in the Alexander terrane. The cherty argillite members of the Iyoukeen and Peratrovich Formations resemble some rocks mapped as the Cannery Formation on Admiralty and Kupreanof Islands, but within the context of their dominantly fossiliferous limestone sections, they would not be confused with Cannery rocks. All other Mississippian units in the Alexander terrane contain rocks that are more calcareous and more carbonaceous than Mississippian rocks of the Cannery Formation. After restoration of $180 \mathrm{~km}$ of offset on the Chatham Strait Fault (Hudson and others, 1981), apparent alignment of lithofacies in the Alexander terrane 
Table 3. Radiometric data for Permian metamorphic and igneous rocks in the Alexander terrane, southeastern Alaska.

\begin{tabular}{|c|c|c|c|c|c|c|c|c|c|c|}
\hline Sample & $\begin{array}{l}\text { Symbol } \\
\text { fig. } 2\end{array}$ & $\begin{array}{l}\text { Latitude } \\
\left({ }^{\circ} \mathbf{N}\right)^{1}\end{array}$ & $\begin{array}{l}\text { Longitude } \\
\left({ }^{\circ} \mathbf{W}\right)^{1}\end{array}$ & Rock type & Mineral & Lab/source & Method & Age $(\mathrm{Ma})^{2}$ & Comment on date & interpretation \\
\hline \multicolumn{11}{|c|}{ Metamorphic rocks } \\
\hline 93PH143C & A & 57.85806 & -134.57444 & \multirow[b]{2}{*}{$\begin{array}{l}\text { amphibolite } \\
\text { retrograded } \\
\text { to } \\
\text { greenschist } \\
\text { facies }\end{array}$} & \multirow{3}{*}{ white mica } & \multirow{4}{*}{$\begin{array}{l}\text { Layer-this } \\
\text { study }\end{array}$} & \multirow{4}{*}{$\mathrm{Ar}-\mathrm{Ar}^{3}$} & $223.2 \pm 2.6$ & $\begin{array}{l}\text { argon loss spectrum, weighted } \\
\text { average age of } 6 \text { fractions, } \\
70.1 \%{ }^{39} \text { Ar release, MSWD }= \\
2.4 \text { (error weighted by the square } \\
\text { root of the MSWD), total gas }= \\
217.8 \pm 1.5 \mathrm{Ma} \text {, last } 2 \text { older steps: } \\
262.9 \pm 3.6 \mathrm{Ma}\end{array}$ & $\begin{array}{l}\text { last two steps } \\
\text { Permian, but } \\
\text { reset by Triassic } \\
\text { overprint }\end{array}$ \\
\hline 93PH127B & B & 57.86861 & -134.41194 & & & & & $246.0 \pm 2.5$ & $\begin{array}{l}\text { total gas age, however, argon } \\
\text { loss spectra with a maximum } \\
\text { age step of } 268.9 \pm 2.7 \mathrm{Ma}(7.1 \% \\
{ }^{39} \mathrm{Ar} \text { release) }\end{array}$ & $\begin{array}{c}\text { Permian } \\
\text { metamorphism, } \\
\text { with argon loss } \\
\text { due to J or K } \\
\text { metamorphism }\end{array}$ \\
\hline 97PH045B & F & 58.03000 & -134.80111 & amphibolite & & & & $261.8 \pm 12.0$ & $\begin{array}{l}\text { weighted average age of } 11 \\
\text { fractions, } 99.6 \%{ }^{39} \text { Ar release, } \\
\text { MSWD }=131 \text { (error weighted } \\
\text { by the square root of the } \\
\text { MSWD), total gas }=260.4 \pm 1.0\end{array}$ & $\begin{array}{c}\text { Permian } \\
\text { metamorphism of } \\
\text { sill dated at } 314 \\
\mathrm{Ma}(\mathrm{U} / \mathrm{Pb} \text {, zircon })\end{array}$ \\
\hline 97PH055B & $\mathrm{E}$ & 58.06389 & -134.50778 & $\begin{array}{l}\text { hornblende } \\
\text { gneiss }\end{array}$ & hornblende & & & $266.0 \pm 4.8$ & $\begin{array}{l}\text { weighted average age of } \\
3 \text { fractions, } 64.1 \%{ }^{39} \mathrm{Ar} \\
\text { release, MSWD }=15.6 \text { (error } \\
\text { weighted by the square root } \\
\text { of the MSWD), but excess } \mathrm{Ar} \\
\text { (errorchron age of } 235 \pm 10.5 \\
\text { Ma, } 10 \text { fractions, }{ }^{40} \mathrm{Ar}^{36} \mathrm{Ar}_{\mathrm{i}}= \\
1060 \pm 130\end{array}$ & $\begin{array}{c}\text { Permian } \\
\text { metamorphism }\end{array}$ \\
\hline
\end{tabular}

Intrusive igneous rocks

\begin{tabular}{|c|c|c|c|c|c|c|c|c|c|c|}
\hline 91SK047A & G & 55.72333 & -132.54667 & $\begin{array}{c}\text { foliated } \\
\text { diorite }\end{array}$ & biotite & & & $280.6 \pm 1.6$ & $\begin{array}{l}\text { plateau age of } 6 \text { fractions, } 81 \% \\
{ }^{39} \mathrm{Ar} \text { release, } \mathrm{MSWD}=1.5\end{array}$ & \multirow{5}{*}{$\begin{array}{l}\text { Permian } \\
\text { magmatism }\end{array}$} \\
\hline \multirow[t]{4}{*}{ 91SK040A } & $\mathrm{H}$ & 55.80240 & -132.50080 & granodiorite & hornblende & $\begin{array}{l}\text { Layer-this } \\
\text { study }\end{array}$ & $\mathrm{Ar}-\mathrm{Ar}$ & $278.3 \pm 10.3$ & $\begin{array}{l}\text { weighted average age of } 4 \text { oldest } \\
\text { fractions, } 47.3 \%{ }^{39} \text { Ar release, } \\
\text { MSWD }=27 \text { (error weighted by } \\
\text { the square root of the MSWD), } \\
\text { total gas }=254.9 \pm 1.8 \mathrm{Ma}\end{array}$ & \\
\hline & I & 55.54640 & -133.09430 & syenite & biotite & $\begin{array}{c}\text { Churkin and } \\
\text { Eberlein, } \\
1975\end{array}$ & \multirow{3}{*}{$\mathrm{K}-\mathrm{Ar}$} & $282 \pm 8$ & \multirow{3}{*}{--} & \\
\hline & $\mathrm{J}$ & 55.01140 & -132.74090 & $\begin{array}{l}\text { quartz } \\
\text { diorite }\end{array}$ & hornblende & \multirow{2}{*}{$\begin{array}{l}\text { Eberlein and } \\
\text { others, } 1983\end{array}$} & & 283 & & \\
\hline & & & & & biotite & & & 293 & & \\
\hline
\end{tabular}

${ }^{1}$ Latitudes and longitudes are NAD27.

${ }^{2}$ All ages quoted at the 1-sigma level, MSWD: Mean Square Weighted Deviates.

${ }^{3}$ See appendix. 
suggests a northwest-southeastward, northeast-facing, (present coordinates) orientation of the southern Alexander arc during the Carboniferous (fig. 12), and the carbonaceous limestonechert facies lies to the southwest of the red and green chert and graywacke-chert facies represented by the Cannery Formation. The important point is that two distinct depositional facies are represented by Carboniferous rocks in the Alexander terrane and they are geographically discrete.

\section{Chert and Limestone of the Porcupine Creek- Tsirku River Area}

Between the Klehini and Tsirku Rivers, thick-bedded metalimestone contains Devonian and Mississippian corals and conodonts (figs. 3, 12; loc. 2, fig. 2 and table 1; Gilbert and others, 1987), and includes laminated gray sooty limestone with bioclastic beds, black phyllite, and as much as 25 percent calcareous siltstone, black slate, and dark-gray metasiltstone. The limestone is depositionally overlain by bedded gray chert in beds as much as $50 \mathrm{~cm}$ thick with phyllitic partings as much as $8 \mathrm{~cm}$ thick. The chert grades upsection to black cherty, pyritic argillite, with lenses of green to black chert as much as $80 \mathrm{~cm}$ thick and lenses of gray metalimestone as much as $80 \mathrm{~cm}$ thick. These carbonaceous limestone-chert beds overlie thick-bedded metamorphosed Devonian and Mississippian limestone and mafic metavolcanic rocks and underlie the black chert and argillite of Porcupine Creek that contains a Permian brachiopod (loc. 1, fig. 2 and table 1), so the limestone-chert beds are inferred to include Carboniferous rocks. Basement to these bedded rocks consists of metamorphic rocks similar to those on Admiralty and Kupreanof Islands that are juxtaposed by faults against the Cannery Formation. The Carboniferous limestone in the Tsirku River area is overlain by chert, graywacke, and argillite similar to that of the Cannery Formation in the Eagle Peak area on Admiralty Island.

\section{lyoukeen Formation}

The Iyoukeen Formation (Loney and others, 1963, 1975) consists of gray fossiliferous limestone and shale best exposed on the Iyoukeen Peninsula of Chichagof Island (fig. 12). The lower member of the Iyoukeen Formation, which averages 130 meters in thickness, is composed of dark-gray, thin-bedded, fine-grained limestone with thin dark-gray chert interbeds and lenses. The limestone contains corals, brachiopods, gastropods, and conodonts. The middle member, which averages $200 \mathrm{~m}$ in thickness, consists of dark-gray, noncalcareous to calcareous, sparsely fossiliferous shale that grades northwestward into dark-gray, yellow-weathering shaly limestone. The upper member, estimated to be as much as 1,000 m thick, is characterized by dark-gray, medium-bedded, fossiliferous limestone with dark-gray, nodular chert lenses. Gypsum commonly occurs at the top of the upper member, indicating a tropical, arid depositional environment. The oldest fossils include conodonts of Kinderhookian or early Early Mississippian age (A.G. Harris, written commun., 1995; Karl, 1999). Corals, brachiopods, and gastropods indicate an Early Mississippian age for the lower and middle members of the Iyoukeen Formation and a late Late Mississippian (late Chesterian) age for the upper member. These rocks represent a carbonaceous limestone-chert facies of the Carboniferous rocks in the Alexander terrane and do not resemble correlative rocks of the Cannery Formation on Admiralty and Kupreanof Islands. The basal contact of the Iyoukeen Formation is unconformable on bimodal volcanic rocks of the Upper Devonian Freshwater Bay Formation. The upper contact of the Iyoukeen Formation is a modern erosional surface. The upward-diminishing proportion of shale and thickening limestone beds suggests that the depositional environment was shoaling over time. Fossil species present indicate warm, shallow water and a high energy environment (A.G. Harris, written commun., 1995), in contrast to the deepwater depositional environment represented by coeval rocks of the Cannery Formation.

\section{Peratrovich Formation}

The Peratrovich Formation of Eberlein and Churkin (1970) consists of bedded dark-gray to black chert overlain by thin- to medium-bedded, dark-gray to black, white-weathering limestone with dark-gray chert nodules, exposed on Prince of Wales Island and small islands near Craig (fig. 12). The limestone contains abundant shelly fossils that indicate a warm, shallow-marine depositional environment (Eberlein and others, 1983). The lower member of the Peratrovich Formation consists of $70 \mathrm{~m}$ of thin-bedded black chert with shaly partings and lenses of fetid limestone that contain Early Mississippian crinoids, corals, and both articulate and inarticulate brachiopods. The middle member consists of at least 25 percent of medium-dark-gray limestone that contains mainly bryozoan and echinoderm fossil debris in a lime mudstone matrix, as well as irregular layers and nodules of black replacement chert. Fossils in the middle member, which is approximately $100 \mathrm{~m}$ thick, indicate that it ranges in age from Osagian to Meramecian, or from late Early Mississippian to early Late Mississippian (Eberlein and Churkin, 1970). The upper member consists locally of dolomitic limestone, with less than 10 percent black chert lenses and nodules. Limestone in the upper member is less than $100 \mathrm{~m}$ thick, medium-dark-gray, fetid, and contains echinoderm and bryozoan fragments in lime mudstone, as well as the corals Lithostrotion, Lithostrotionella, Diphyllum, and Sociophyllum and the foraminifer Tourmayella of Meramecian age, and the foraminifer Pseudoendothyra and the fusulinid Eostaffela of Chesterian age (Eberlein and others, 1983). At Shelikof Island, aquagene tuff and breccia at the top of the Devonian Port Refugio Formation are conformably overlain by thin-bedded, dark-gray to black chert and limestone of the Peratrovich Formation. Near Craig, the Peratrovich Formation overlies the late Early through Late Devonian Wadleigh Limestone with apparent conformity and is overlain by calcareous clastic rocks of the Pennsylvanian Klawak 
Formation. The change from basal sooty argillite and chert to shelly limestone and dolostone suggests upward shoaling of a restricted basin in a warm marine depositional environment (Eberlein and others, 1983). These rocks, which closely resemble the Iyoukeen Formation, are a component of the carbonaceous limestone-chert facies of the Carboniferous rocks in the Alexander terrane; they do not resemble age-correlative rocks in the Cannery Formation.

\section{Saginaw Bay Formation}

Fossil age control for the Saginaw Bay Formation has improved since the unit was named by Muffler in 1967. Fossils from the lower volcanic member of the Saginaw Bay Formation in the Keku Islets that yielded "probable Mississippian" and Pennsylvanian ages (Muffler, 1967; see Alaska Paleontologic Database, http://www.alaskafossil.org/) are now known to be Devonian in age on the basis of conodont collections from the basalt member and the overlying black chert member in Saginaw Bay (see A.G. Harris, 1983, in Alaska Paleontologic Database, http://www.alaskafossil.org/). The chert and limestone member contains fossils that were assigned a tentative Mississippian or Pennsylvanian age (J.T. Dutro, oral commun., 1963, in Muffler, 1967), and the uppermost silty limestone member contains early Middle Pennsylvanian fossils (J.T. Dutro and R.C. Douglass, 1961, in Muffler, 1967). A Carboniferous age is still inferred for the chert and limestone member, which consists of thin- to medium-bedded, light-brown-weathering calcareous chert and subordinate thin-bedded, medium-gray, brown-weathering, cherty fossilfragmental limestone that is locally dolomitic (Muffler, 1967). This unit, which is at least $122 \mathrm{~m}$ thick, does not resemble any age-correlative rocks in the Cannery Formation.

\section{Summary of Mississippian Chert-Bearing Units}

Thin-bedded black chert associated with thick sections of fetid, fossiliferous Mississippian limestone in the Iyoukeen and Peratrovich Formations represents a low-oxygen or restrictedbasin depositional environment. Calcareous chert and cherty fossil-fragmental limestone of the Saginaw Bay Formation similarly represents a shallow-marine low-oxygen depositional environment. Correlative varicolored ribbon chert and graywacke-chert turbidites of the Cannery Formation reflect a deepmarine, more oxygenated depositional environment. The Carboniferous rocks of the Porcupine Creek-Tsirku River area are less cherty than rocks of the Cannery Formation and somewhat resemble rocks of the Iyoukeen and Peratrovich Formations, but their stratigraphic context, including underlying metabasalt and marble and overlying Permian chert, argillite, and volcaniclastic rocks, is similar to that of the Cannery Formation. The carbonaceous Carboniferous chert-limestone sections of the Iyoukeen, Saginaw Bay, and Peratrovich Formations form a discrete belt that lies to the southwest of the varicolored Carboniferous cherts of Windfall Harbor, Cannery Cove, and
Kupreanof Island that have been mapped in the Cannery Formation (fig. 12; Loney, 1964; Lathram and others, 1965).

\section{Pennsylvanian Lithostratigraphic Units in the Alexander Terrane}

Pennsylvanian lithostratigraphic units that are sparsely distributed in the Alexander terrane may be underrepresented, owing to low rates of deposition, uplift and erosion, or absence of datable rocks. Dated Pennsylvanian sedimentary rocks are dominantly limestone and calcarenite. Limestone is sparse in the Cannery Formation, and owing to an absence of limestone or to low rates of deposition and sparse fossils in chert and argillite sections, the Pennsylvanian component of the Cannery Formation may be poorly documented. The absence of Pennsylvanian limestone distinguishes the Cannery Formation from other Pennsylvanian units in southeastern Alaska.

\section{Saginaw Bay Formation}

After the initial definition of the Saginaw Bay Formation by Muffler (1967), the age of the Saginaw Bay Formation was extended to Devonian through Pennsylvanian by Brew and others (1984). The lower volcanic and black chert members are Devonian, and the chert and limestone member contains fossils of tentative Mississippian or Pennsylvanian age (Muffler, 1967; Brew and others, 1984). Fossils of early Middle Pennsylvanian age were reported from the uppermost silty limestone member (J.T. Dutro and R.C. Douglass, 1961, in Muffler, 1967), which is conformably overlain by fossiliferous early Permian siltstone of the Halleck Formation. The thickness of the silty limestone member is inferred to be several tens of meters.

\section{Crinoidal Limestone of Keku Strait}

An unnamed crinoidal limestone unit was defined for fossiliferous Carboniferous limestone in Keku Strait by Muffler (1967) because it consisted of medium-bedded to massive, fossil-fragmental limestone unlike the limestone in Saginaw Bay. The crinoidal limestone contains Pennsylvanian foraminifers and fusulinids (see R.C. Douglass, 1969, in Alaska Paleontologic Database, http://www.alaskafossil.org/), Early and Middle Pennsylvanian conodonts (see A.G. Harris, 1980, in Alaska Paleontologic Database, http:/www.alaskafossil. org/), and late Early and Middle Pennsylvanian brachiopods (see J.T. Dutro, 1983, in Alaska Paleontologic Database, http:// www.alaskafossil.org/). The crinoidal limestone stratigraphically overlies massive Devonian limestone that does not resemble any part of the Devonian section in Saginaw Bay, but like the rocks in Saginaw Bay, it represents a shallow-water depositional environment that contrasts with the deep-water depositional environment represented by correlative bedded chert and chert-graywacke beds in the Cannery Formation. 


\section{Ladrones Limestone}

The Ladrones Limestone (Eberlein and Churkin, 1970), mapped north of Sukkwan Island, consists of light-gray, thickbedded to massive, sublithographic limestone containing matrix-supported pellets, oolites, foraminifers, fusulinids, shelly debris, and light-gray chert nodules. It depositionally overlies the Peratrovich Formation and is inferred to be laterally gradational to the Klawak Formation, which contains the same fusulinids, Fusulinella sp. (Eberlein and Churkin, 1970; Eberlein and others, 1983; see R.C. Douglass, 1969, in Alaska Paleontologic Database, http://www.alaskafossil.org/). The Ladrones Limestone, which also contains corals, brachiopods, and conodonts of Early and Middle Pennsylvanian age (Eberlein and others, 1983; Savage and Barkeley, 1985), represents a shallow-water depositional environment that constitutes part of a southern belt of rocks in the Alexander terrane, contrasting with the northern belt of chert and argillite in the Cannery Formation, that represents a deep-water depositional environment.

\section{Klawak Formation}

The Klawak Formation (Eberlein and Churkin, 1970), which depositionally overlies the Peratrovich Formation near Klawock, consists of 150 to $300 \mathrm{~m}$ of gray calcareous sandstone and siltstone containing matrix-supported chert pebbles, arenaceous limestone, and fossil-fragmental limestone. The sandstone beds are graded and crossbedded. Limestone of the Klawak Formation contains abundant fusulinids, including Fusulina sp., Fusulinella sp., Millerella, Nankinella, and Staffella, as well as abundant productid brachiopods, solitary and colonial corals, bryozoans, and the trace fossil Spirophyton (Churkin and Eberlein, 1975). G.H. Girty (in Buddington and Chapin, 1929, p. 116-117) noted that the fossils collected from the Saginaw Bay and Klawak units "... have no counterpart of any age in the United States," that Fusulina and Fusulinella are known from the Mountain Limestone of Russia, and that some species in the Saginaw and Klawak collections resemble fossils described from the Gzelian Stage of the Pennsylvanian in Russia. Eberlein and Churkin (1970, p. 59) noted that the small size and simple structure of the fusulinids suggest a Pennsylvanian rather than a Permian age, and stated that A.K. Armstrong considered the brachiopods and corals to be Early Pennsylvanian. Limestone of the Klawak Formation also contains Early and Middle Pennsylvanian conodonts (Savage and Barkeley, 1985). The bioclastic limestone and crossbedded sandstone of the Klawak Formation indicate shoaling deposition after deposition of cherty limestone of the Peratrovich Formation, in contrast to agecorrelative deepwater chert of the Cannery Formation.

\section{Summary of Pennsylvanian Lithostratigraphic Units}

Pennsylvanian fossils in the Cannery Formation and in the Porcupine Creek area occur in radiolarian chert or limestone lenses in argillite. All other stratigraphic units in the Alexander terrane that contain Pennsylvanian fossils are limestone-dominated sections. The chert- and argillite-dominant Pennsylvanian rocks in the Cannery Formation and in the Porcupine Creek area, which represent deepwater depositional environments, occur only in the northern part of the Alexander terrane. In contrast, the limestone-dominant Pennsylvanian rocks of the Saginaw Bay, Ladrones, and Klawak Formations, which represent shallow-water depositional facies, occur in the southern part of the Alexander terrane (fig. 12).

\section{Permian Lithostratigraphic Units in the Alexander Terrane}

Early Permian lithostratigraphic units in the Alexander terrane include the Halleck Formation, an informal argillite and slate unit in the William Henry Bay area, and an informal volcanic unit in the same area. Several longer-ranging units contain early Permian fossils, including the Cannery Formation and the informally named Porcupine Slate of Redman and others (1985). The Pybus Formation, which unconformably overlies the Halleck and Cannery Formations, contains late early and early late Permian brachiopods and conodonts. Except for two localities near William Henry Bay at which limestone lenses in chert contain both late early and early late Permian fossils (locs. 8, 9, table 2), siliceous and carbonaceous argillite of late Permian age is unknown in the Alexander terrane. The broad distribution of the Pybus Formation throughout southeastern Alaska supports the hypothesis of a regional unconformity and a regional change from various depositional environments in the early Permian to a more uniform warm, shallow-marine depositional environment in the late Permian.

\section{Halleck Formation}

The early Permian Halleck Formation is correlative with the upper part of the Cannery Formation. The Halleck Formation, named for rocks in Halleck Harbor on Kuiu Island by Muffler (1967), consists of siltstone, sandstone, limestone, conglomerate, and mafic volcanic and volcaniclastic rocks (figs. 2, 3, 13). The dominant rock type is dark-gray calcareous siltstone that grades to silty fossiliferous limestone. The siltstone contains thin beds of tan-weathering fossil-fragmental limestone containing rugose corals (fig. $13 A$; loc. 44 , fig. 2 and table 1), that grades upward to fossiliferous crossbedded calcareous sandstone, volcaniclastic debris flows (fig. 13B), and polymictic conglomerate. The sandstone and conglomerate contain clasts of unmetamorphosed mafic volcanic rocks, limestone, and chert. Pillow basalt flows (fig. 13C), pillow breccia, and volcaniclastic deposits locally are more than $100 \mathrm{~m}$ thick in the middle of the Halleck section. Fossils in the sedimentary and volcanic rocks are early Permian and Permian (locs. 42-44, fig. 2 and table 1; Muffler, 1967; Brew and others, 1984). The Halleck Formation, which is less than 
200 m thick, conformably overlies the Carboniferous Saginaw Bay Formation and unconformably and disconformably underlies the Pybus Formation (fig. 13C; Muffler, 1967). The Halleck Formation, which was inferred to represent a shallow-water depositional facies to the southwest of the Cannery Formation (Muffler, 1967) depositionally overlies the shallow-water Mississippian and Pennsylvanian rocks that form a belt southwest of deepwater Carboniferous rocks of the Cannery Formation.

\section{Rocks of the William Henry Bay Area}

Unnamed argillite and limestone mapped near William Henry Bay in the Chilkat Mountains (unit Pal, fig. 2) contain early Permian fossils (locs. 8, 9, fig. 2 and tables 1, 2; Lathram and others, 1958). The rocks include various discontinuous sections, including (1) dark gray phyllite with intervals of greenstone, overlain by calcareous graywacke and argillite; (2) chert breccia in an argillaceous matrix; (3) as much as 100 $\mathrm{m}$ of brownish-gray fossiliferous limestone; (4) interbedded nodular brownish-gray limestone, greenish-brown bedded chert, and limestone with chert clasts; and (5) interbedded dark-gray limestone, siltstone, calcareous graywacke, argillite, and chert-clast calcareous conglomerate. A related section of more than $200 \mathrm{~m}$ of basalt is mapped separately as unit $\mathrm{Pv}$ (fig. 2). The stratigraphic order within this unit is undefined. Only fault contacts have been observed at the boundaries of the unit, which is estimated to be at least $1,000 \mathrm{~m}$ thick (Lathram and others, 1958) but may be structurally repeated. The rocks extend into the northeast corner of Glacier Bay National Park (Brew, 1997). Limestone in this section contains the brachiopod Septacamera stupenda Grant that is a hallmark of limestone of the Pybus Formation, and a limestone lens in the bedded chert section contains late early Permian conodonts, including Hindeodus excavatus (Behnken) and Neogondolella
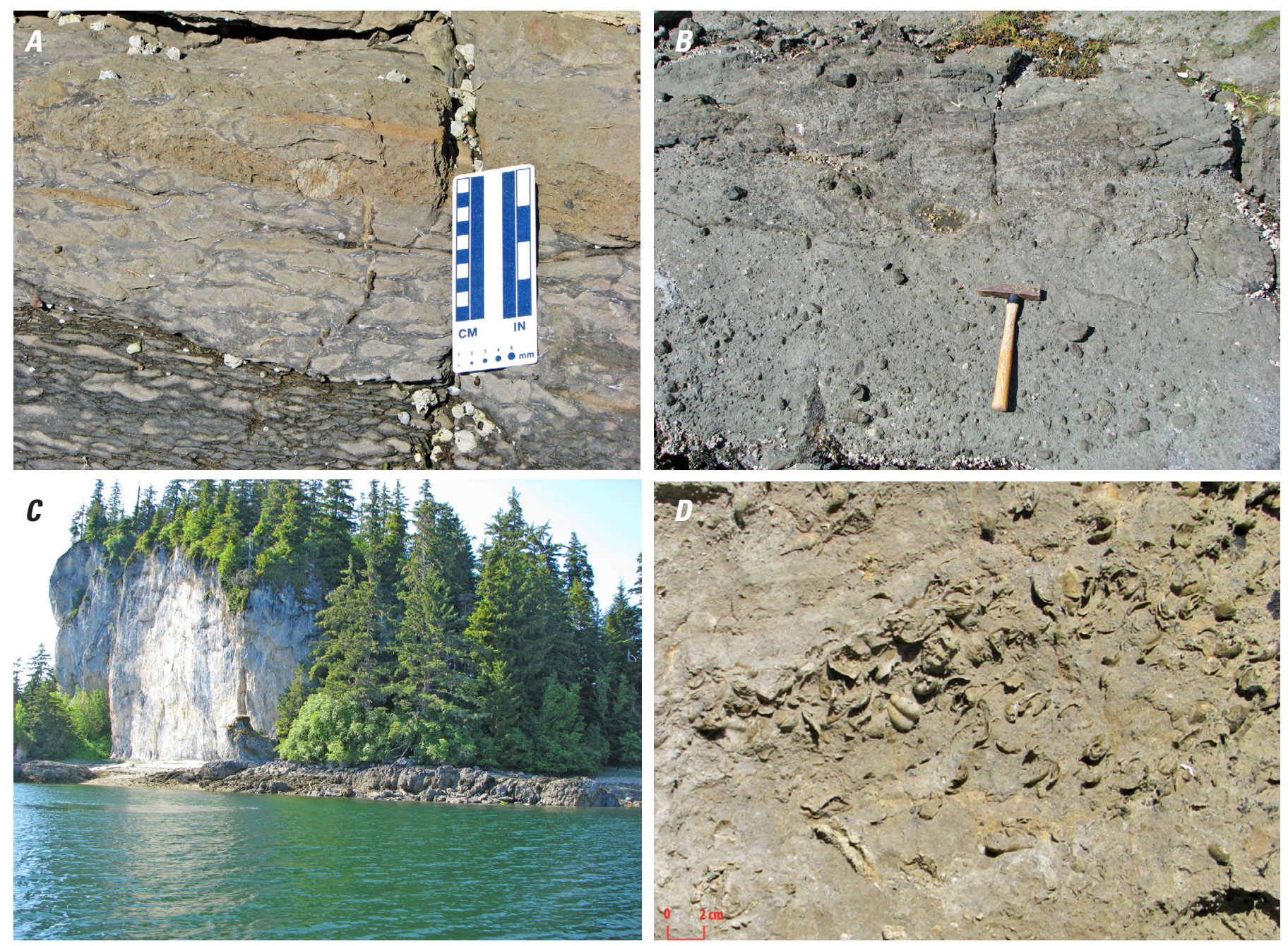

Figure 13. Bedding and a rugose coral $(A)$ and volcaniclastic rocks $(B)$ from the type locality of the Halleck Formation at Halleck Harbor, Saginaw Bay, southeastern Alaska (figs. 1, 2). Limestone of the Pybus Formation overlying pillow basalt of the Halleck Formation $(C)$ and fossil hash of the Pybus Formation $(D)$ are from exposures in Saginaw Bay. 
idahoensis (Youngquist, Hawley, and Miller), as well as Septacamera stupenda Grant (locs. 8, 9, fig. 2 and tables 1 and 2; see Alaska Paleontologic Database, http://www.alaskafossil. org/). The age conflict between brachiopods and conodonts in this limestone lens needs further study but suggests that the unit may include components that are equivalent to the Halleck, Cannery, and Pybus Formations. More work is also needed to determine the stratigraphic order within the unit. The rocks are overlain by a section of dark-gray to black, redweathering chert, siliceous argillite, and graywacke at least $300 \mathrm{~m}$ thick, which is in turn overlain by basalt and agglomerate of inferred Permian or Triassic age (Lathram and others, 1958). These rocks have not been mapped in detail and may include tectonically interleaved components of the Cannery and Pybus Formations, the Halleck and Pybus Formations, or lateral facies equivalents of those units.

\section{Slate of Porcupine Creek}

North of the Chilkat Mountains, in the Porcupine CreekTsirku River area (fig. 2), the Porcupine Slate of Redman and others (1985), which consists of black slate and phyllite and dark-gray metalimestone, was assigned a Devonian through Triassic age by Gilbert and others (1987). The unit includes black argillaceous metachert, banded metasiltstone, volcaniclastic metagraywacke, granule to pebble breccia, and a few layers of metabasalt that overlie a band of massive metalimestone containing megafossils and conodonts of Devonian and Mississippian age. The black slate is sooty to siliceous and locally calcareous where it grades to lenses of sooty limestone. The calcareous siltstone and sooty metalimestone together compose about 25 percent of the unit; the metalimestone layers are as much as several meters thick. Fossils from a poorly designated locality in the lower part of the section on Porcupine Creek are Artinskian (late early Permian), include the brachiopods Productus cf. P. mammatus and P. gruenwaldi, Spirifer cf. S. marconi and S. muskheylensis, and Camarophoria $\mathrm{cf}$. C. margaritovi, and have affinities with brachiopods from the Artinsk Sandstone of the Ural Mountains and the Russian Platform (loc.1, fig. 2 and table 1; Wright, 1904; see G.H. Girty in Eakin, 1919). The same fossils were identified in collections from Saginaw, Herring, and Pybus Bays (Wright, 1906; Eakin, 1919). These fossils, which are unknown from the North American Craton, suggest that the Alexander terrane was isolated from North America during the Permian.

In the lower Porcupine Creek section, gray chert, in beds as much as $50 \mathrm{~cm}$ thick, with phyllitic partings as much as $8 \mathrm{~cm}$ thick, depositionally overlies thick-bedded to massive metalimestone containing corals and Devonian-Mississippian conodonts (Gilbert and others, 1987). The chert grades upsection to black cherty, pyritic, sooty and graphitic argillite, with lenses of green to black chert and gray metalimestone as much as $80 \mathrm{~cm}$ thick, which grades up to a more siliceous slate containing siliciclastic sandstone beds (Eakin, 1919). The cherty argillite composes about 70 percent, the chert about 25 percent, and the limestone about 5 percent of this part of the section (Gilbert and others, 1987). The rocks closely resemble rocks east of Kake and in the Duncan Canal area. In the upper Porcupine Creek section, mafic sills and indistinctly lumpy (pillow?) flows, as much as $10 \mathrm{~m}$ thick, that include centimeter-scale lenses of metalimestone compose about 40 percent of the section; and black chert, in beds as much as $15 \mathrm{~cm}$ thick, cherty black argillite, and millimeter- to centimeter-scale laminated metalimestone compose 60 percent of the section. The top of the section consists of black cherty argillite that includes chert beds as much as $10 \mathrm{~cm}$ thick, and argillite with wispy millimeter-scale starved ripples of siltstone. The section is folded, faulted, and discontinuously exposed, so its true thickness is unknown, although the band of mafic volcanic rocks is discrete and not repeated.

The cherty argillaceous rocks are overlain by a 350-m-thick section of pillow basalt, pillow breccia, and rhyolite that yielded a Late Triassic U-Pb zircon age of $213 \pm 5$ m.y. (Green and Greig, 2004), which provides a minimum age for the slate. The pillows are well formed and include interpillow lenses of limestone and volcaniclastic debris. The pillow basalt in the Triassic section is associated with mineralized calcareous metasedimentary rocks and argillaceous limestone that contain volcanogenic massive sulfide deposits (Hawley, 1976; Still, 1984). Above the mineralized zones is a calcareous matrix-supported breccia containing angular blocks of volcanic rocks that resembles calcareous matrix debris flows in the Hyd Group on Admiralty Island. Triassic fossils were reported from the Glacier Creek area, but no fossil localities were designated (Gilbert and others, 1987; Green and Greig, 2004).

The presence of Permian brachiopods from a poorly located limestone layer in lower Porcupine Creek (Eakins, 1919) suggests either that the belt of massive limestone grades from Devonian and Mississippian through Permian with little or no Pennsylvanian deposition represented, or that the base of the argillite section is early Permian or only slightly older. As in the Greens Creek-Eagle Peak area, without fossils the Permian sooty argillite is difficult to distinguish from Triassic sooty argillite (Lathram and others, 1960; 1965; Gilbert and others, 1987), although the thick section of pillow basalt is a reliable indicator for the Triassic section in the Porcupine Creek area. A basal Triassic conglomerate containing clasts of Paleozoic rocks that is common in the Hyd Group elsewhere in the Alexander terrane has not been identified in the Porcupine Creek area. The Permian-Triassic boundary may be within the sooty argillite, or it may be represented by the base of the massive pillow basalt in the Porcupine Creek area.

\section{Correlative Permian Rocks in British Columbia on Trend with Porcupine Creek}

Carboniferous and Permian rocks mapped by Watson (1948) along strike from the Porcupine Slate of Redman and others (1985) in British Columbia, Canada, have not been mapped in detail and are included in an Ordovician through 
Triassic unit (Journeay and others, 2000) or in one of the Silurian through Permian units of Mihalynuk and others (1993). One such Silurian through Permian unit, SPsa, is a black, sooty-weathering argillite with minor thinly laminated limestone interbeds that "may be mistaken for uTrTs" (Mihalynuk and others, 1993), a conundrum nearly identical to that of the slate of Porcupine Creek and the sooty argillite at Eagle Peak on Admiralty Island. Host rocks to the Late Triassic Windy Craggy VMS deposit unconformably overlie gray limestone, at least 1,000 m thick, containing Devonian fossils and black limy argillite containing late Eifelian to early Givetian conodonts (MacIntyre, 1984), and the base of the Triassic section consists of black limy argillite and siltstone with thin intercalations of tuff that are lithologically correlated with rocks nearby containing Late Triassic (Norian) conodonts (MacIntyre,1983, 1984; Peter and Scott, 1999). Although the host rocks of the Windy Craggy VMS deposit are correlated with the Hyd Group that hosts the VMS deposits in the Alexander terrane (MacIntyre, 1984, Green and Greig, 2004), Permian and older rocks similar to those of the Cannery Formation have not been identified near the Windy Craggy VMS deposit.

\section{Pybus Formation}

The Pybus Dolomite was named by Loney (1964) for fossiliferous cherty dolostone that is well exposed in Pybus Bay on Admiralty Island (figs. 2, 14). The abundance of limestone in the unit on Kuiu and Kupreanof Islands (fig. 10) led Muffler (1967) to rename it the "Pybus Formation". The dolostone is sugary, fine- to medium-grained, and dark-gray to pale yellowish-brown on fresh and weathered surfaces. Beds, which are as much as $3 \mathrm{~m}$ thick, commonly contain grayish-blue chert lenses and nodules and silicified fossils (fig. 13D) that typically include several species of the distinctive brachiopod Septacamera, in addition to Stenocisma, Neospirifir, Spirifirella, and Anidanthus of Permian and early late Permian age (locs. 45, 46, fig. 2 and table 2; Loney, 1964). The age of the unit was revised to early Permian on the basis of Kungurian corals (Rowett, 1975) and is herein extended to include rocks mapped as limestone of the Pybus Formation that contain early late Permian conodonts (loc. 47, fig. 2 and table 2) and brachiopods including Septacamera pybensis Grant (loc. 52, fig. 2 and table 2; Grant, 1971). Conodonts recovered from the Pybus Formation include Neogondolella phosphorensis and Xaniognathus of late Roadian through early Capitanian (early late Permian) age (loc. 47, fig. 2 and table 2), in contrast to the late early Permian conodonts species that accompany Septacamera stupenda in the William Henry Bay section (locs. 8, 9, fig. 2 and table 2), which is not mapped as the Pybus Formation. Although the contact is not exposed, bedding in the Pybus Formation has an angular discordance relative to that of the adjacent Cannery Formation in Pybus Bay, so an unconformable contact is inferred (Loney, 1964). The Pybus Formation is unconformably overlain by basal breccia of the Hyd Group on southern Admiralty Island. A measured section of the Pybus Formation in Pybus Bay indicates a thickness of 133 m (Loney, 1964); the thickness of similar cherty limestone was estimated at $137 \mathrm{~m}$ on Kuiu Island (Wright and Wright, 1908) and at $152 \mathrm{~m}$ on Kupreanof Island (Muffler, 1967).

On the southeast shore of Suemez Island (figs. 2, 12), a 93-m-thick section of fossiliferous bedded brownish-gray limestone containing Permian brachiopods structurally underlies Mississippian black bedded chert, argillite, and rhythmically bedded black fetid limestone assigned to the middle and upper members of the Peratrovich Formation. Fossils in the Permian limestone on Suemez Island include silicified Globiella? sp. and Septacamera, as well as spiriferid, productid, orthotetacid, and dictyoclostid brachiopods, ramose bryozoans, horn corals, and echinoderms that closely resemble fossils from the Pybus Formation in Saginaw Bay and Pybus Bay (loc. 53, fig. 2 and table 2; Buddington and Chapin, 1929). The Permian limestone on Suemez Island is herein assigned to the Pybus Formation.

White limestone and dolostone on Kupreanof and Kuiu Islands (fig. 2) include light-gray and blue beds, lenses, nodules, and fragments of chert, similar to that of dolostone in the Pybus Formation, and contain fossils assigned by G.H. Girty to the Permian, that are correlated with fossils from the Artinsk Sandstone of the Ural Mountains in Russia (Buddington and Chapin, 1929). The limestone on Kuiu Island unconformably or disconformably overlies shallow-water silty limestone of the early Permian Halleck Formation in Saginaw Bay and unconformably overlies chert of the Cannery Formation on Kupreanof Island (Muffler, 1967). This relation was inferred to represent a "collision and amalgamation of two unlike tectonostratigraphic terranes in latest early Permian time as postulated by Berg, Jones, and Coney (1978)" (Jones and others, 1981). Muffler (1967) suggested that the lithologic differences between chert of inferred Permian age (now known to be Devonian and Mississippian) in the Cannery Formation near Kake and in the Permian silty limestone in Saginaw Bay, which are both overlain by the Pybus Formation, was due to Permian shortening of depositional facies which predated deposition of the Pybus Formation. New fossil information (locs. 33, 34, fig. 2 and table 2; Karl and others, 1999; see Alaska Paleontologic Database, http://www.alaskafossil.org/) indicates that the early Permian silty limestone of the Halleck Formation in Saginaw Bay contrasts with the early Permian chert and siliceous argillite and silty limestone of the Cannery Formation west of Duncan Canal on Kupreanof Island, in support of the interpretation by Muffler (1967). Differences between the Devonian rocks beneath the Cannery Formation on northern and southern Admiralty Island, and between the rocks beneath the Cannery Formation on southern Admiralty and Kupreanof Islands, as discussed above, suggest that collision and amalgamation of two or more contrasting arcs occurred during deposition of rocks of the Cannery Formation now exposed on Admiralty Island. The Permian metamorphic belt on Admiralty Island, which may include the undated metamorphic rocks on northern Kupreanof Island (figs. 2, 15), 
supports the interpretation of a collision-related deformation event. The Permian deformation postulated by Muffler (1967) is also supported by the regional unconformity beneath the Pybus Formation throughout the Alexander terrane. The contrast in sedimentary facies and deformation between early Permian rocks of the Cannery Formation and the Halleck Formation across Keku Strait may represent a sedimentary facies change and shortening of a single arc, or may reflect a Permian juxtaposition of arcs or a "terrane" amalgamation boundary, as suggested by Berg and others (1978). The contrast in basement rock types beneath the Cannery Formation and the Halleck Formation supports the hypothesis of Berg and others (1978).

\section{Discussion}

Rocks in Pybus Bay and Keku Strait that were originally included in the Cannery Formation on the basis of similar lithology (Muffler, 1967) are not identical, although both areas include bedded chert; however, the cherts in the two areas differ in age. The ages reported by Jones and others (1981) from Keku Strait were used to revise the age of a unit containing Permian fossils in its type area in Pybus Bay to a unit with a Devonian and Mississippian age. This age reassignment for the Cannery Formation ignored the rock types and fossils in the type area, as well as the concept of using a well-documented type section of a formation as a standard of comparison for both age and lithology. By Jones and others' redefinition, the rocks of Cannery Cove are excluded from the Cannery Formation. The rocks at Kake that contain Devonian fossils do not resemble the rocks in Cannery Cove in either age or lithology. The graywacke-chert couplets that compose the turbidites at Cannery Cove are distinctive and have not been described in the vicinity of Kake. East of Kake, bedded chert and graywacke-argillite turbidites are mapped as the Cannery Formation (Muffler, 1967; Brew and others, 1984; Karl and others, 1999), and these cherts have yielded radiolarians of Mississippian through Permian age. Graywacke-chert turbidites, which have been described only at Pybus Bay and Windfall Harbor, contain Mississippian(?) and Mississippian through Permian radiolarians.

All chert in the Alexander terrane need not be assigned to the Cannery Formation. Black bedded chert that contains rare lenses of Late Devonian limestone has been described at Kake and in Hawk Inlet. On the basis of both lithology and age, the chert at Kake might reasonably be correlated with the chert in Hawk Inlet. The black chert at Saginaw Bay, which is

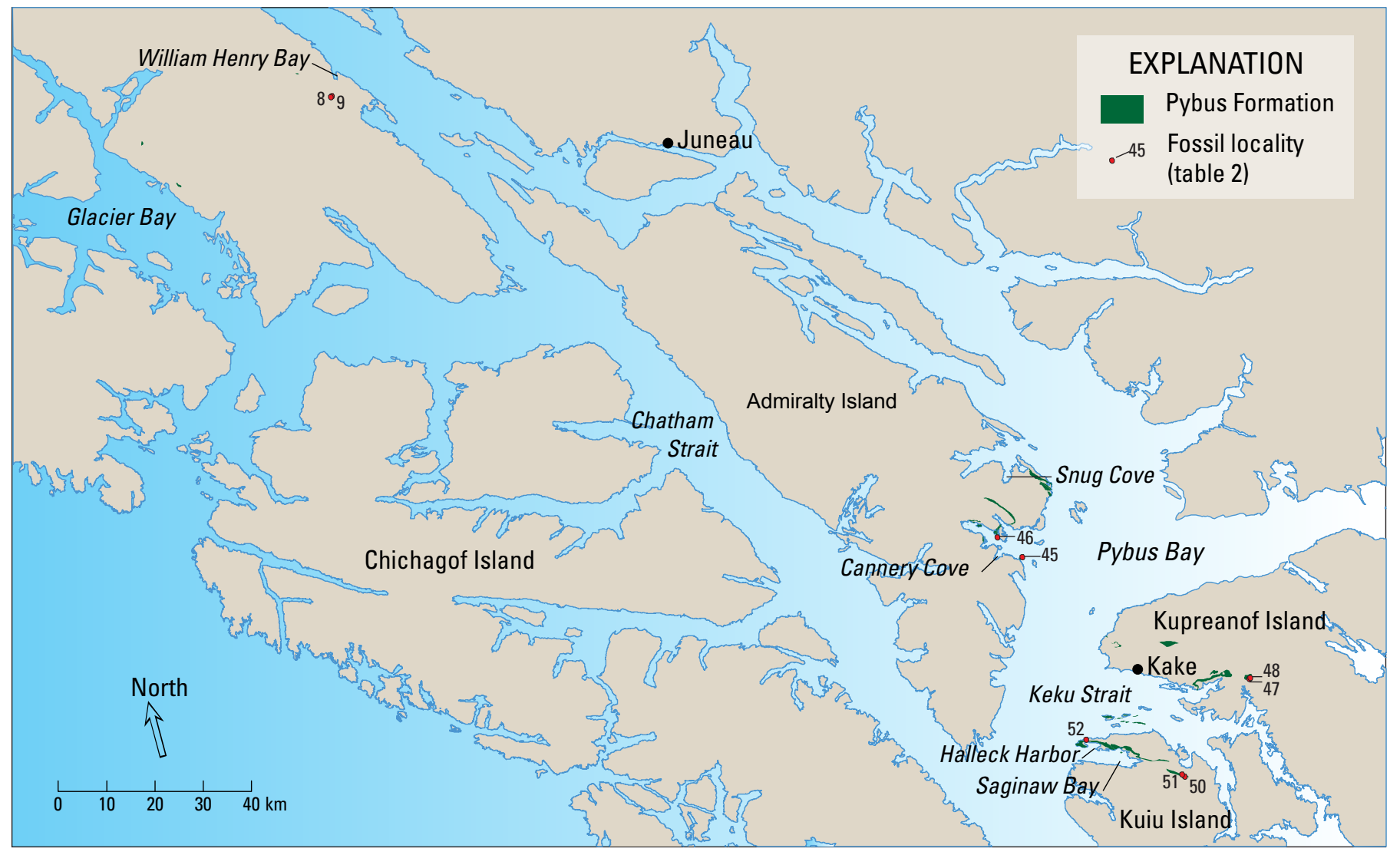

Figure 14. Southeastern Alaska, showing distribution of the late Permian Pybus Formation and age-equivalent rocks in the Alexander terrane (figs. 1, 2). 
interbedded with Devonian limestone, does not resemble the chert at Kake or in Hawk Inlet in either aspect or context.

As described above, the chert in Hawk Inlet was originally assigned to the Retreat Group by Lathram and others (1965) and later by Brew and Ford (1985) to their unit Mzps. The rocks at Point Retreat on Admiralty Island, the type locality for the Retreat Group, include greenschist and quartzite intruded by quartz diorite that yielded concordant Neoproterozoic U-Pb ages of 545-547 Ma (Karl and others, 2006). The chert in Hawk Inlet, which contains Late Devonian fossils, does not resemble the rocks at Point Retreat, so it should not be included in the Retreat Group or the Mesozoic unit of Brew and Ford (1985). Black chert with limestone lenses is absent in Cannery Cove: the chert in Hawk Inlet does not correlate with the rocks in Cannery Cove in either age or lithology, nor in degree of deformation or metamorphic grade. Although the chert in Hawk Inlet is similar in both age and lithology to chert assigned to the Cannery Formation at Kake, it cannot unequivocally be assigned to the Cannery Formation because it is significantly more deformed and metamorphosed than the
Permian argillite assigned to the Cannery Formation in Hawk Inlet and dated nearby at Eagle Peak. The Cannery Formation can reasonably be extended to be a Mississippian through Permian unit on the basis of distinctive rock types and fossils in both Cannery Cove and Windfall Harbor and the relatively continuous outcrops of similar rock types between the two areas, as well as between occurrences of Mississippian and Permian chert, graywacke, and argillite on Kupreanof Island. Because a boundary between Devonian and Mississippian chert on Kupreanof Island is difficult to map, the simplest solution to this problem is to extend the age of the Cannery Formation to Late Devonian through early Permian. However, the base of the Cannery Formation appears to be a time-transgressive boundary. Black chert and argillite associated with limestone containing Silurian-Devonian conodonts in the Hood Bay Formation near Cannery Cove contributes distinctive clasts of deformed black chert with quartz veinlets to sandstone and conglomerate of the Cannery Formation on Admiralty Island. The absence of the deformation and metamorphism of the Hood Bay Formation and the chert of

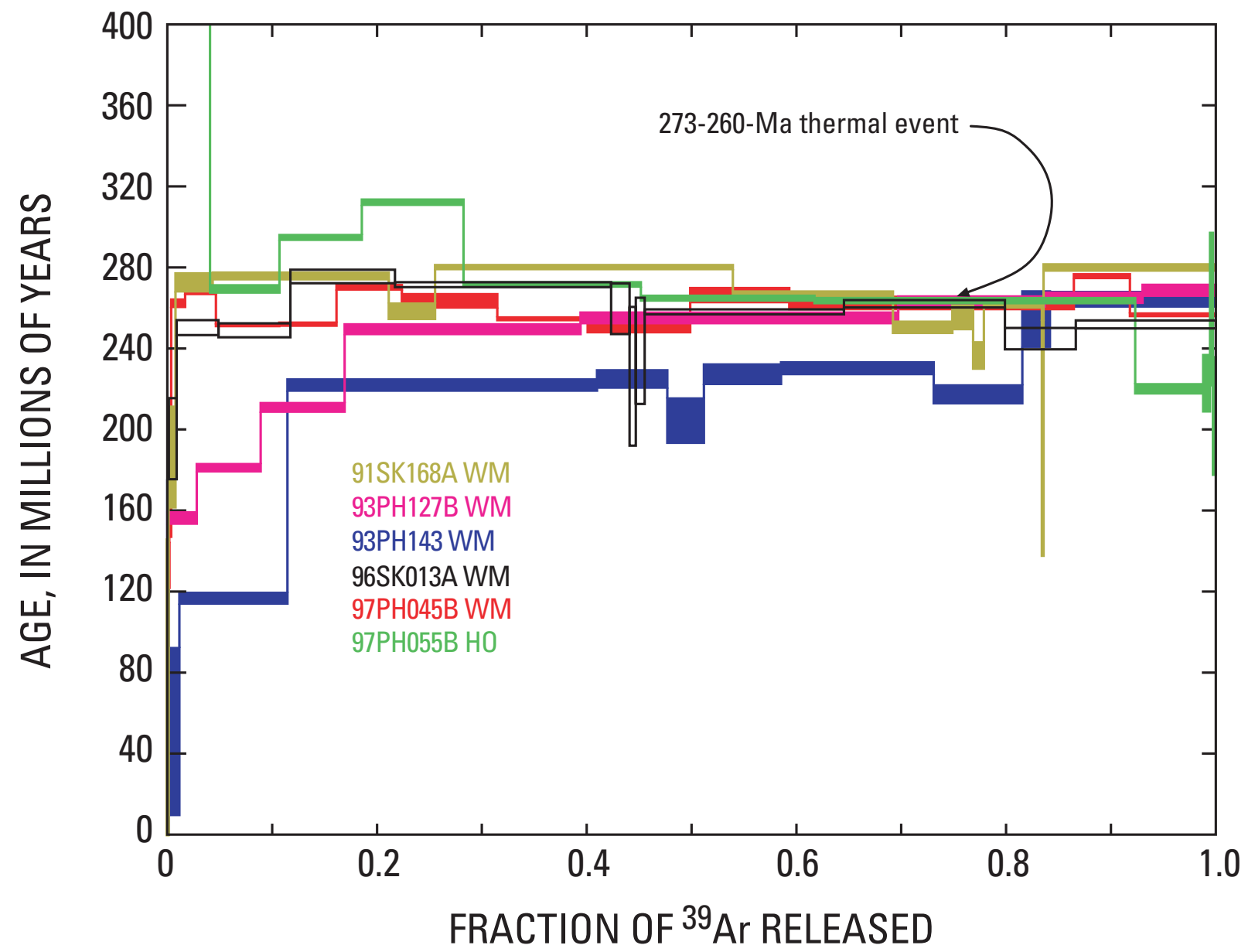

Figure 15. ${ }^{40} \mathrm{Ar} /{ }^{39} \mathrm{Ar}$ age spectra for minerals dated from metamorphic rocks on Admiralty Island, southeastern Alaska (figs. 1, 2; table 3), showing pervasiveness of the Permian thermal event that disturbed argon systematics in minerals. 
Hawk Inlet in the Cannery Formation on Admiralty Island indicates a post-Devonian, pre-Cannery deformation event on Admiralty Island.

The Cannery Formation overlies a post-Devonian unconformity on Admiralty Island but apparently was deposited continuously from Devonian through early Permian time on Kupreanof Island. The simplest way to explain these observations is to consider the Cannery Formation to be a time-transgressive unit that is oldest near Kake and younger to the northeast in Duncan Canal and on Admiralty Island. Late Devonian chert-bearing units, including the chert in Hawk Inlet and the chert member of the Saginaw Bay Formation, have separate depositional, metamorphic, and deformational histories and could have been juxtaposed against the stratigraphic section that includes the Cannery Formation at different times. Judging from chert clasts in clastic strata of the Cannery Formation, rocks of the Hood Bay Formation were deposited adjacent to, and contributing to the Cannery Formation during post-Devonian, and no later than early Permian time. If the metamorphic event that resulted in early Permian mineral cooling ages for the metamorphic rocks on northern Admiralty Island is the same event that affected the metamorphosed chert in Hawk Inlet, then the chert in Hawk Inlet was juxtaposed with rocks of the Cannery Formation after the early Permian. Conglomerate of the early Permian Halleck Formation contains clasts of chert that could have been derived from the Cannery Formation at Kake or the Saginaw Bay Formation on Kuiu Island, suggesting an early Permian deformation event to Muffler (1967) and Jones and others (1981). Both the Halleck Formation and the Cannery Formation are unconformably overlain by the late early to early late Permian Pybus Formation, so apparently both the rocks that include the Saginaw Bay Formation and the rocks that include the Cannery Formation were juxtaposed before deposition of the Pybus Formation.

Because chert pebbles in conglomerate of the early Permian Halleck Formation contain Mississippian and Devonian radiolarians, Jones and others (1981) chose to restrict the age of the Cannery Formation to Mississippian and Devonian in order to constrain chert of the Cannery Formation as a clastic source for early Permian conglomerate of the Halleck Formation and signal a collision between the rocks on Kupreanof Island and the rocks on Kuiu Island (fig. 2). Such an age restriction is unnecessary if the uplift was transgressive. Alternatively, Mississippian and Devonian chert clasts in the Halleck Formation could have been derived from the Saginaw Bay Formation. Rather than revise the age of the Cannery Formation to Mississippian and Devonian and ignore the Permian fossils at the type locality, Jones and others (1981) could also have (1) correlated the chert at Kake with coeval chert in the Saginaw Bay Formation or (2) redefined the Cannery Formation as Devonian through Permian.

The simplest solution to this stratigraphic problem is to include both the Late Devonian through Permian chert section on Kupreanof Island and the Mississippian through Permian graywacke, chert, argillite, and carbonate exposed at the type locality on Admiralty Island in the Cannery Formation. We suggest assigning the chert at Kake to a black chert member of Late Devonian age in the Cannery Formation so that it can be independently correlated with other Late Devonian cherts. Accordingly, we propose an informal lower chert member of Devonian age, a middle chert-graywacke member of Mississippian to Permian age, and an upper argillite-chert member of Permian age.

Rocks assigned to the Cannery Formation in this report thus contain fossils as old as Famennian, or Late Devonian, and as young as early late Permian, extending from approximately 374 to $260 \mathrm{Ma}$, according to the time scales of Gradstein and others (2004), Walker and Geissman (2009). Approximately 134 m.y. is an unusually long period of time for continuity of a lithostratigraphic unit that reflects a particular depositional environment. The Cannery Formation includes various sedimentary and volcanic rock types that indicate intermittent tectonic activity, but is dominated by chert and argillite that indicate slow sedimentation in a stable environment over a large area.

\section{Implications of Early Permian Sedimentary Facies in the Alexander Terrane}

Early Permian sedimentary and volcanic rocks are widespread in the Alexander terrane (figs. 2, 16). They are commonly fossiliferous, and only marine lithofacies have been recognized. The volcanic rocks are entirely mafic, with trace- and rare-earth-element signatures that indicate various ocean-floor to volcanic-arc affinities on various geochemicaldiscriminant diagrams (fig. 8). After restoration of $180 \mathrm{~km}$ of dextral offset on the Chatham Strait Fault on the basis of the criteria of Hudson and others (1981), a review of the distribution of shallow-water and deepwater depositional facies for early Permian rocks in the Alexander terrane shown in figure 16, though somewhat disrupted by folding and faulting, indicates a distribution of rock types that resolves into regional northwesterly striking trends of early Permian intrusive rocks, Permian mafic volcanic and volcaniclastic rocks, and five lithofacies that represent early Permian sedimentary rocks. The five early Permian sedimentary lithofacies shown in figure 2 include (1) fossiliferous bedded limestone (PMl), (2) silty limestone and calcareous siltstone ( $\mathrm{Phl}),(3)$ sooty carbonaceous siltstone, chert, and limestone (Pal), (4) graywackechert turbidites and argillite-matrix debris flows (PDca), and (5) chert and siliceous claystone (PDc). Bedded fossiliferous limestone and bioclastic limestone represent shallow-water bioherms and their talus aprons that are interbedded with volcanic rocks in Halleck Harbor and the Chilkat Mountains (fig. 2). Fossiliferous silty limestone, calcareous siltstone, and calcarenite also represent shallow-water deposits. Carbonaceous argillite and gray chert represent zones of either (1) 
upwelling and high biologic productivity along slopes below the carbonate compensation depth or (2) restricted basins. Graywacke turbidites and debris flows may represent slope basins, arc basins, rift basins, or submarine-canyon and trench facies deposits (Mutti and Ricchi-Lucchi, 1972). Light-gray to red siliceous claystone represents well-oxygenated deepwater deposits (Bostrom, 1976).

The early Permian depositional facies shown in figure 16 indicate that siliceous deepwater sedimentary rocks lie to the north of calcareous shallow-water rocks. The early Permian shallow-water sedimentary rocks mostly lie to the north of the early Permian intrusive rocks. This spatial relation of lithofacies and igneous rocks suggests that the inferred Permian arc was facing northeastward. Local anastomosing shear, boudinage, and blocks-in-matrix textures, such as those observed in the deepwater sedimentary facies at Snug Cove, Towers Arm, and Zarembo Island, are inferred to reflect accretionary processes at an arc margin or, possibly, an accretionary zone between two or more arc fragments and are consistent with a northeast-facing early Permian arc on the southern Alexander terrane. Ductile structures in metamorphic rocks on Admiralty Island are dated by early Permian metamorphic-mineral ages (figs. 2, 4C, 11; table 3; appendix) and are structurally juxtaposed with the early Permian accretionary-complex rocks suggest a lower-plate structural position for the rocks in the northern Alexander terrane. Stratigraphic differences between Paleozoic protoliths of metamorphosed rocks of the northern Alexander terrane and unmetamorphosed Paleozoic rocks of the southern Alexander terrane were previously recognized, and these areas were referred to as the Admiralty and

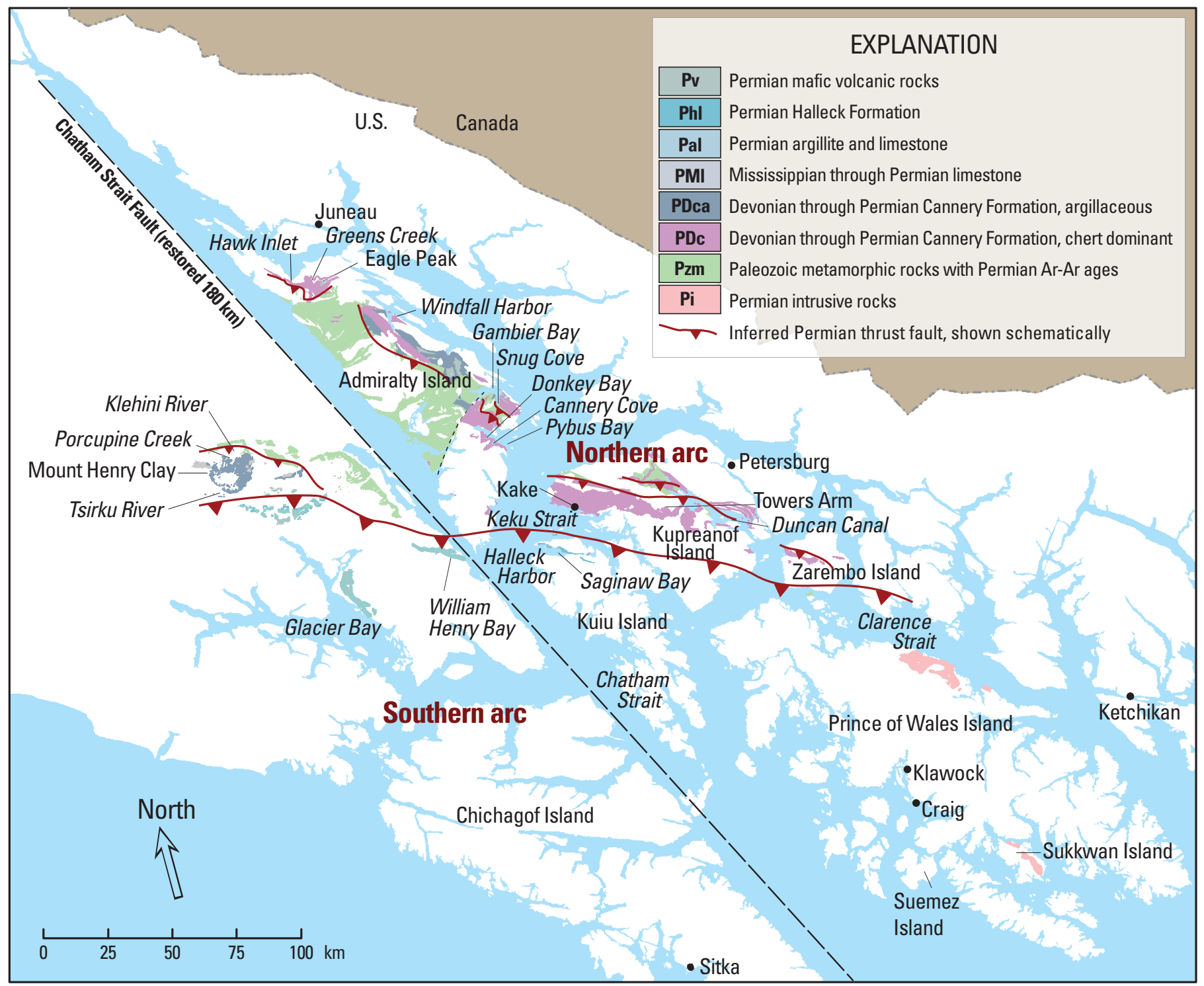

Figure 16. Southeastern Alaska, showing distribution of Permian sedimentary, metamorphic, and igneous rocks and inferred model for their tectonic setting (figs. 1, 2). 
Craig subterranes, respectively (Berg and others, 1978). The early Permian metamorphic-mineral ages support juxtaposition of these separate stratigraphic sequences during the early Permian, as proposed by Muffler (1967) and Jones and others (1981). The distribution of early Permian sedimentary facies, deformation textures, metamorphic rocks, and intermediatecomposition intrusive rocks in southeastern Alaska described above is compatible with an early Permian collision of two (or more) Paleozoic arcs that are now components of the Alexander terrane.

Although it contains fossils as old as latest early Permian, for simplicity the Pybus Formation is shown only on the late Permian map (fig. 14), because it overlies the huge diversity of older rocks in the Alexander terrane, provides a minimum age for a regional unconformity, and represents a discrete regional time horizon.

\section{Early Permian Metamorphic Rocks}

Metamorphic rocks on Admiralty Island include the Retreat Group, the Gambier Bay and Hood Bay Formations, and informally named greenschist-facies metasedimentary and metavolcanic rocks. The Retreat Group consists of schist and gneiss intruded by Neoproterozoic plutons (Karl and others, 2006). The Gambier Bay Formation consists mostly of semischistose to massive greenstone and marble that have Devonian protoliths (Loney, 1964; Lathram and others, 1965). Mineral assemblages include quartz-muscovite-chlorite-albite, quartz-talc-calcite, talc-dolomite, and chlorite-epidote-calcite, but the presence of relict pyroxene, hornblende, and calcic plagioclase indicates that metamorphic equilibrium was not achieved (Loney, 1964). Chlorite-epidote-calcite schist and phyllite are the most abundant rock types, commonly containing euhedral pyroxene as much as $2 \mathrm{~mm}$ long, and less commonly, hornblende. Relict primary augite grains with overgrowths of blue sodic amphibole that also grows across the foliation of the greenschist-facies minerals (Loney, 1964, p. 16) suggests that low-temperature, high-pressure metamorphism succeeded greenschist-facies metamorphism. The metamorphic rocks have northeast vergent ductile stuctures. Locally, reduction in the size of pyroxene and augite grains and milling of the greenschist-facies minerals into phyllonite and mylonite led Loney (1964) to infer subsequent low temperature-deformation.

The Hood Bay Formation consists of Ordovician through Devonian black siliceous argillite and chert, with subordinate graywacke, limestone, and volcanic rocks (Loney, 1964; Carter, 1977). Rocks of the Hood Bay Formation contain secondary chlorite, pyrite, quartz veins, and conodonts with a color-alteration index (CAI) of 5 (A.G. Harris, written commun., 1995), which corresponds to recrystallization temperatures of $300-480^{\circ} \mathrm{C}$ (Epstein and others, 1977; Königshof, 2003), a range consistent with greenschist-facies metamorphism (Miyashiro, 1973). The Gambier Bay and
Hood Bay Formations unconformably underlie, and locally are faulted against, or thrust over, the Cannery Formation. Metamorphic rocks similar to those on Admiralty Island are faulted over and against rocks of the Cannery Formation on northern Kupreanof Island (Karl and others, 1999).

Informally named metasedimentary and metavolcanic rocks mapped north of the Gambier Bay Formation on Admiralty Island contain white mica that yielded consistent early Permian ${ }^{40} \mathrm{Ar} /{ }^{39} \mathrm{Ar}$ cooling ages (fig. 15; table 3; appendix). These ages are broadly distributed between 273 and $260 \mathrm{Ma}$, date northeast vergent ductile deformation, and record a regional metamorphic event. Rocks in the Cannery Formation contain secondary chlorite (figs. $5 A, 5 B$ ) but not secondary white mica. Clasts of deformed and veined chert similar to that of the Hood Bay Formation in sandstone of the Cannery Formation in Pybus Bay, and blocks of Devonian marble and greenstone similar to that of the Gambier Bay Formation in argillite of the Cannery Formation in Snug Cove, lead us to conclude that early Permian deformation resulted in greenschist-, and, locally, possible blueschist-facies metamorphism of Devonian and older rocks on Admiralty Island and that these deformed rocks were uplifted and incorporated into early Permian parts of the Cannery Formation by tectonic and sedimentary processes. Stratigraphic-layer compositions, sedimentary facies, and textures of Permian rocks, as well as metamorphic ages, grades, and low-temperature-deformation features of these rocks, are consistent with accretionary-complex deposition and deformation during collision of separate Paleozoic arcs during the early Permian.

Deformation that placed the higher-grade greenschistfacies metamorphic rocks on Admiralty Island over the lowergrade Cannery Formation is inferred to be Mesozoic, related to regional shortening of the Alexander terrane during collision with other terranes and North America (Karl and others, 1998; Haeussler and others, 1999).

\section{Early Permian Intrusive Rocks}

Early Permian calc-alkaline and alkaline intrusive rocks were emplaced in the southern part Alexander terrane (figs. 2, 17) on Prince of Wales and Sukkwan Islands. These unmetamorphosed plutons intrude Ordovician and Silurian volcanic and sedimentary rocks and have biotite and hornblende K-Ar and Ar-Ar ages ranging from 278 to $293 \mathrm{Ma}$ (table 3; Eberlein and others, 1983). The early Permian plutons have gabbroic to syenitic compositions that are inferred to represent arc magmatism, but are relatively alkaline in comparison with typical arc magmas above subducting oceanic crust, as described by Gill (1981) and summarized by Pearce and Peat (1995) and Kelemen and others (2003). These Permian intrusive rocks have high $\mathrm{K}_{2} \mathrm{O}$ and $\mathrm{Na}_{2} \mathrm{O}$ contents (table 4 ), and a diagram of immobile trace elements, on which $\mathrm{Zr} / \mathrm{TiO}_{2}$ ratio serves as a fractionation index and $\mathrm{Nb} / \mathrm{Y}$ ratio as an alkalinity index (fig. 17A; Winchester and Floyd, 1977), demonstrates their 
Table 4. Chemical analyses of Permian intrusive rocks in the Alexander terrane, southeastern Alaska.

\begin{tabular}{|c|c|c|c|c|c|}
\hline Sample no. & CDZ3 & 91SK020A & 91SK040A & 91SK047 & 01SK128A \\
\hline Lab no. & D385846 & D385886 & D385843 & D385845 & C192561 \\
\hline Latitude & 55.872 & 55.882 & 55.803 & 55.723 & 55.542 \\
\hline Longitude & -132.618 & -132.817 & -132.502 & -132.547 & -133.097 \\
\hline Quadrangle & \multicolumn{5}{|c|}{ Craig } \\
\hline Rock unit & \multicolumn{5}{|c|}{$\mathrm{Pi}$} \\
\hline Rock type & $\begin{array}{c}\text { quartz } \\
\text { monzonite }\end{array}$ & \multicolumn{2}{|c|}{ granodiorite } & gabbro & syenite \\
\hline Data file & Ur37 & Ur39 & Ur37 & Ur37 & MRP-03411 \\
\hline $\mathrm{SiO}_{2}$ & 56.600 & 63.900 & 63.600 & 49.800 & 62.4 \\
\hline $\mathrm{Al}_{2} \mathrm{O}_{3}$ & 17.400 & 16.700 & 18.600 & 16.800 & 16.0 \\
\hline $\mathrm{FeTO}_{3}$ & 7.170 & 3.450 & 2.790 & 10.500 & 0.76 \\
\hline MgO & 2.630 & 2.160 & 0.480 & 3.750 & 0.41 \\
\hline $\mathrm{CaO}$ & 5.490 & 4.660 & 1.610 & 7.080 & 5.17 \\
\hline $\mathrm{Na}_{2} \mathrm{O}$ & 4.520 & 5.100 & 6.400 & 4.710 & 5.53 \\
\hline $\mathrm{K}_{2} \mathrm{O}$ & 3.270 & 2.290 & 4.870 & 2.040 & 4.93 \\
\hline $\mathrm{TiO}_{2}$ & 0.750 & 0.370 & 0.280 & 1.860 & 0.44 \\
\hline $\mathrm{P}_{2} \mathrm{O}_{5}$ & 0.370 & 0.140 & 0.110 & 1.520 & 0.20 \\
\hline MnO & 0.120 & 0.060 & 0.050 & 0.190 & 0.04 \\
\hline LOI & 0.940 & 0.390 & 0.320 & 0.900 & 3.32 \\
\hline Total & 99.26 & 99.22 & 99.11 & 98.95 & 99.20 \\
\hline $\mathbf{R b}$ & 58.000 & 41.000 & 68.000 & 40.000 & 88 \\
\hline $\mathrm{Sr}$ & 630.000 & 920.000 & 530.000 & 990.000 & 533 \\
\hline Cs & 0.392 & 0.193 & 0.299 & 0.869 & 0.10 \\
\hline $\mathrm{Ba}$ & 860.000 & 720.000 & 840.000 & 550.000 & 746 \\
\hline Th & 3.720 & 4.760 & 26.900 & 9.060 & 31.30 \\
\hline $\mathbf{U}$ & 3.170 & 1.990 & 5.780 & 2.650 & 10.10 \\
\hline La & 23.400 & 18.800 & 106.000 & 78.000 & 114.00 \\
\hline Ce & 50.700 & 36.500 & 168.000 & 176.000 & 196.00 \\
\hline Nd & 24.800 & 14.800 & 40.700 & 72.600 & 50.60 \\
\hline Sm & 5.550 & 2.800 & 5.150 & 11.500 & 7.58 \\
\hline Eu & 1.360 & 0.760 & 1.250 & 3.280 & 1.04 \\
\hline Gd & 4.490 & 2.110 & 3.360 & 9.630 & 6.80 \\
\hline Tb & 0.766 & 0.284 & 0.442 & 1.270 & 0.92 \\
\hline Ho & & & & & 1.40 \\
\hline $\mathrm{Tm}$ & 0.454 & 0.170 & & & 0.73 \\
\hline
\end{tabular}

\begin{tabular}{|c|c|c|c|c|c|}
\hline Sample no. & CDZ3 & 91SK020A & 91SK040A & 91SK047 & 01SK128A \\
\hline Lab no. & D385846 & D385886 & D385843 & D385845 & C192561 \\
\hline Latitude & 55.872 & 55.882 & 55.803 & 55.723 & 55.542 \\
\hline Longitude & -132.618 & -132.817 & -132.502 & -132.547 & -133.097 \\
\hline Quadrangle & \multicolumn{5}{|c|}{ Craig } \\
\hline Rock unit & \multicolumn{5}{|c|}{$\mathrm{Pi}$} \\
\hline Rock type & $\begin{array}{c}\text { quartz } \\
\text { monzonite }\end{array}$ & \multicolumn{2}{|c|}{ granodiorite } & gabbro & syenite \\
\hline $\mathbf{Y b}$ & 2.810 & 1.080 & 2.240 & 3.290 & 4.83 \\
\hline Lu & 0.411 & 0.167 & 0.362 & 0.455 & 0.84 \\
\hline $\mathrm{Zr}$ & 146.000 & 124.000 & 465.000 & 335.000 & 590 \\
\hline Hf & 3.660 & 2.940 & 9.670 & 6.130 & 12.50 \\
\hline Ta & 0.465 & 0.440 & 2.360 & 4.130 & 9.77 \\
\hline $\mathbf{W}$ & & & & & $<5$ \\
\hline Sc & 12.500 & 7.050 & 1.630 & 11.700 & 2.36 \\
\hline $\mathrm{Cr}$ & 20.000 & 62.000 & 20.000 & 20.000 & $<3$ \\
\hline Co & 14.500 & 10.500 & 2.630 & 20.600 & 0.57 \\
\hline $\mathrm{Ni}$ & 23.000 & 25.000 & 10.000 & 10.000 & 3 \\
\hline Zn & 57.000 & 28.000 & 26.000 & 83.000 & 64 \\
\hline As & & & & & 1.35 \\
\hline Sb & 0.793 & 0.132 & 0.044 & 0.090 & 1.73 \\
\hline Au(ppb) & & & & & 0.55 \\
\hline $\mathrm{Ag}$ & & & & & $<1$ \\
\hline $\mathrm{Bi}$ & & & & & $<5$ \\
\hline $\mathrm{Br}$ & & & & & $<1$ \\
\hline Cd & & & & & $<1$ \\
\hline $\mathrm{Cu}$ & 29.000 & 10.000 & 10.000 & 20.000 & 3 \\
\hline Ga & & & & & 21 \\
\hline $\mathrm{Ge}$ & & & & & $<2$ \\
\hline Mo & & & & & 11 \\
\hline $\mathrm{Nb}$ & 12.000 & 10.000 & 40.000 & 66.000 & 136 \\
\hline $\mathbf{P b}$ & & & & & 9 \\
\hline Se & & & & & $<1$ \\
\hline Sn & & & & & 4 \\
\hline v & & & & & 18 \\
\hline $\mathbf{Y}$ & 28.000 & 10.000 & 18.000 & 28.000 & 35 \\
\hline
\end{tabular}


alkalinity. Incompatible high-field-strength elements (HFSEs), such as $\mathrm{Zr}, \mathrm{Y}, \mathrm{Nb}, \mathrm{Yb}, \mathrm{Ga}$, and $\mathrm{Ta}$, are immobile during hydrothermal alteration and metamorphism up to middleamphibolite grade (Pearce and Norry, 1979; Pearce, 1982; Pearce and others, 1984; Pearce and Peat, 1995). The Ta/ $\mathrm{Yb}$ ratio is unaffected by partial melting and crystal fractionation, and correlates well with the proportion of terrigenous subduction component in a magma (McDermott and others, 1993; Pearce and Peate, 1995). On the diagram of Pearce and others (1984), the Permian intrusive rocks in the Alexander terrane show a range $\mathrm{Ta} / \mathrm{Yb}$ ratios that fall in arc and withinplate fields, indicating that these rocks were not derived from simple subduction of oceanic crust beneath the Alexander arc. These ratios could result from an arc-arc collision, involvement of an evolved arc source, or involvement of some other non-mid-ocean-ridge basaltic (MORB) source (fig. 17B). A modern analog for the Permian intrusive rocks of the southern Alexander terrane could be the New Hebrides arc. Within 2 m.y. of the collision of the Entrecasteaux edifice (of uncertain plateau or arc composition), the chemistry of magma produced in the part of the New Hebrides arc above this specific collision changed to more alkalic compositions, and Sr-, Nd-, and $\mathrm{Pb}$-isotopic ratios in the youngest magmas changed to reflect more evolved magma sources with respect to the parts of the New Hebrides arc that overlie subduction of normal oceanic crust and has tholeiitic chemistry and primitive isotopic signatures (Laport and others, 1998). A 2 m.y. period is finer than the resolution of the methods used to date the Permian intrusive rocks in the southern Alexander terrane, but the compositional variation in these plutons of similar age plotted in figure $17 B$ may reflect differences in subducted-crustal compositions during the collision of the Admiralty (northern Alexander) and Craig (southern Alexander) arcs during the Permian, similar to what has been observed in the modern New Hebrides arc.

The $\mathrm{Zr}-\mathrm{Ga} / \mathrm{Al}$ diagram of Whalen and others (1987) serves to reinforce the A-type granitic chemistry of the syenite from Klawock (fig. 17C), which is the only sample that has Ga data. This syenite is K-feldspar porphyritic, and some of the phenocrysts have sodic plagioclase rims, a rapakivi texture that is typical of A-type granitic rocks (Dall'Agnol and Carvalho de Oliveira, 2007). Biotite needles are finely disseminated in the groundmass, and mafic minerals compose less than 5 volume percent of the rock. The syenite contains little

Figure 17. Compositional diagrams showing geochemical affinities of Permian intrusive rocks of the Alexander terrane, southeastern Alaska (figs. 1, 2), on the basis of limited data (table 4). From Winchester and Floyd (1977). $A, \mathrm{Zr} / \mathrm{TiO}_{2}$ ratio serves as a fractionation index, $\mathrm{Nb} / \mathrm{Y}$ ratio as an alkalinity index. From Pearce and others (1984). B, Ta versus $\mathrm{Yb}$ contents separate extension-related rocks from arc rocks. From Whalen and others (1987). $C$, in diagram Zr-Ga/ Al ratio corroborates within-plate magmatism indicated in figure $17 B$. Element contents are plotted in parts per million.
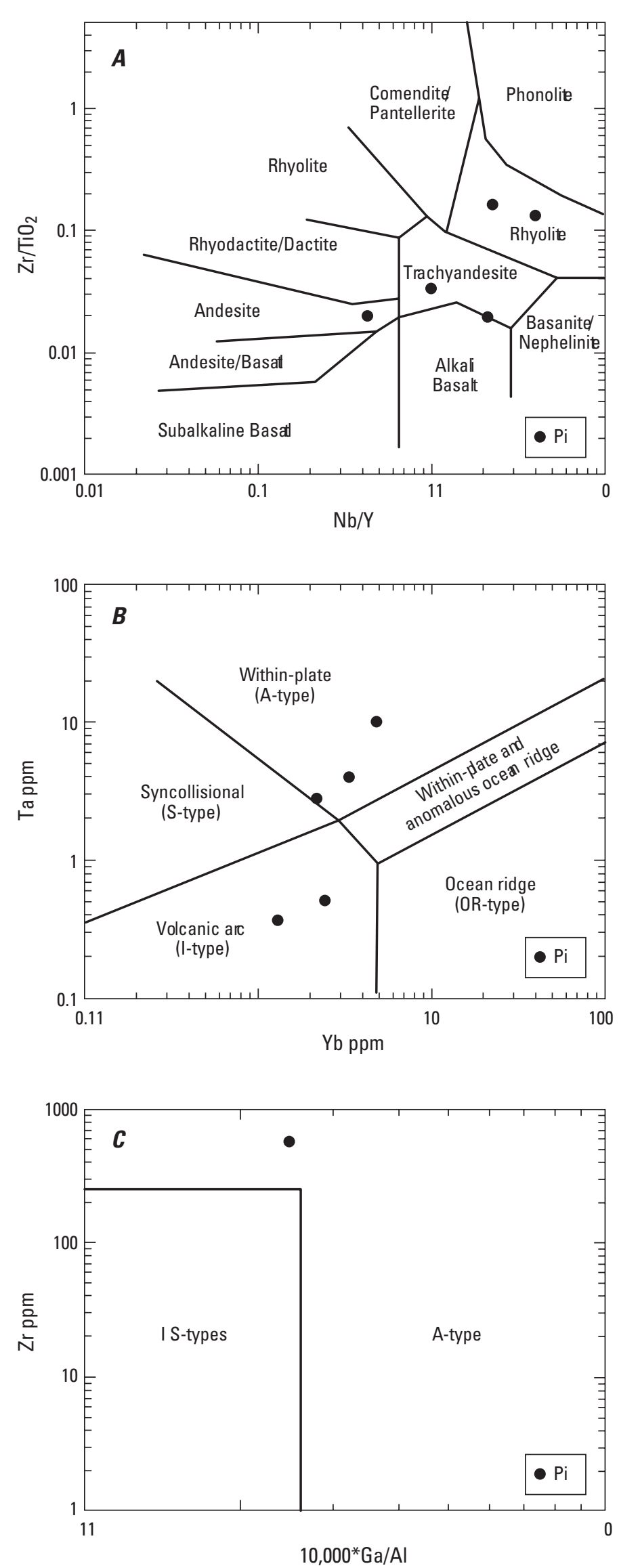
or no quartz and has accessory sphene and apatite. The syenite grades to sodic diorite, which contains as much as 15 volume percent mafic minerals, including hornblende and aegerine augite (Eberlein and others, 1983). Enrichment in highly charged cations like $\mathrm{Zr}$ and $\mathrm{Ga}$ (fig. 17C) cannot be produced by differentiation alone, and so this distinctive chemistry is inferred to reflect partial melting of anhydrous sources that are enriched in $\mathrm{F}$, which forms stable complexes with $\mathrm{Zr}$ and $\mathrm{Ga}$, while $\mathrm{Al}$ is trapped in plagioclase (Whalen and others, 1987). Whalen and others (1987) concluded that A-type granite suites exhibit considerable variation in chemical composition and grade toward I- and S-type granitic compositions, owing to heterogeneous primary sources, varying amounts of extraction of earlier melt phases, and(or) tectonic juxtaposition or interleaving of diverse terranes. Compositional diversity is reflected in figure $17 A-C$ for the Permian intrusive rocks of the Alexander terrane. Whalen and others (1987) inferred that such depleted magma sources are most common in reactivated orogenic belts, an interpretation compatible with such a longlived, evolved, composite arc as the Craig subterrane/southern Alexander arc of the Alexander terrane.

\section{Summary and Conclusions}

A review of the rocks and fossils assigned to the Cannery Formation in southeastern Alaska indicates that revisions to the unit in 1981 excluded rocks of the type area from the unit. A simple solution to this problem is to extend the age range of the Cannery Formation to include rocks of similar age and lithology to those in the type area. Devonian cherty rocks in the Keku Strait area that are only grossly similar in lithology by virtue of the fact they include bedded chert, but differ significantly in age, might better be recognized as an independent unit but are locally difficult to distinguish from other rocks in the Cannery Formation without fossil ages. Assigning all the cherty rocks in the Alexander terrane to the Cannery Formation is unreasonable, and where cherts are distinguishable as independent units, such as the chert in Hawk Inlet, the Saginaw Bay Formation, and the Iyoukeen and Peratrovich Formations, they should be assigned to appropriate units. The apparently gradational boundary between Devonian and Permian cherty rocks on Kupreanof Island presents a problem that is most easily solved with a longranging, Late Devonian through early Permian lithostratigraphic unit, and by distinguishing the Devonian chert as a lower member of the Cannery Formation.

Although early Permian rocks appear to gradationally overlie Devonian through Pennsylvanian rocks on Kupreanof Island, they do not on Admiralty Island, where an unconformity occurs between Devonian rocks and Carboniferous and early Permian rocks. On Admiralty Island, the Devonian rocks of the Gambier and Hood Bay Formations do not lithologically resemble rocks of the Cannery Formation, and these rocks, as well as the Devonian cherty rocks in Hawk Inlet (in which protoliths do resemble rocks of the Cannery Formation), are significantly more deformed and metamorphosed than rocks assigned to the Cannery Formation. The Cannery Formation thus apparently includes a regional Carboniferous or early Permian unconformity, expressed through clast compositions in the conglomerates on Admiralty Island, on Kupreanof Island, and in Keku Strait, that records a deformation event within its more regional depositional history. This conclusion has significant implications for the tectonic history of the Alexander terrane. Early Permian metamorphic and igneous ages for other rocks of the Alexander terrane support the interpretation that the unconformity reflects an early Permian orogenic event, which variously, and, possibly, transgressively affected different components of the Alexander terrane.

Early Permian rocks form northwest-trending belts in the Alexander terrane, indicating that deepwater, open-marine depositional facies lie to the north and east and shallow-water facies rocks lie to the southwest. Metamorphic rocks with early Permian mineral-cooling ages also lie to the northeast of the shallow-water-facies rocks. Early Permian intermediatecomposition intrusive rocks inferred to represent the roots of a magmatic arc lie to the south of early Permian shallow-water sedimentary and volcanic rocks, suggesting that the southern part of the Alexander terrane was a north-facing (present coordinates) arc during the early Permian. Early Permian metamorphic ages for the rocks on Admiralty Island in the northern Alexander terrane record ductile northeast vergent deformation and indicate crustal thickening in this area, possibly due to a collision of pre-Permian arcs. Differences in the pre-Permian stratigraphy on Admiralty and Kupreanof Islands with respect to rocks of the southwestern part of the Alexander terrane on Chichagof, Kuiu, and Prince of Wales Islands suggest an early Permian collision of separate oceanic arcs that have previously been referred to as the Admiralty (northern) and Craig (southern) subterranes. Late early to early late Permian conglomeratic carbonate rocks, including the Pybus Formation, that represent shallow-water depositional facies are ubiquitous throughout the northern and southern components of the Alexander terrane, do not form a northwest-striking belt, and may reflect regional uplift following collision of the two (or more?) components of the Alexander terrane. Permian fossils in the Pybus Formation and correlative limestone in the Alexander terrane have Uralian rather than North American affinities (G.H. Girty, in Wright, 1904, Eakin, 1919, and Buddington and Chapin, 1929; Grant, 1971), suggesting that the Alexander composite arc remained isolated from North America until after the Permian.

\section{Acknowledgments}

We thank Keith Labay of the U.S. Geological Survey for his assistance with map graphics, Ken Helmold of the Alaska Division of Oil and Gas for his assistance with photomicrographs, Julie Dumoulin of the U.S. Geological Survey and Cathy Connor of the University of Alaska Southeast for their constructive and helpful reviews of the manuscript, and Robert Blodgett for geologic-names review. 


\section{References Cited}

Berg, H.C., Jones, D.L., and Coney, P.J., 1978, Map showing pre-Cenozoic tectonostratigraphic terranes of southeastern Alaska and adjacent areas: U.S. Geological Survey Open-File Report 78-1085, 2 sheets, scale $1: 1,000,000$.

Bostrom, K., 1976, Particulate and dissolved matter as sources for pelagic sediments: Stockholm Contributions to Geology, v. 30, p. 15-79.

Brew, D.A., 1997, Reconnaissance bedrock geologic map of Glacier Bay National Park, Alaska, in Glacier Bay Ecosystem GIS CDROM: U.S. Geological Survey, Biological Resources Division [Available from J. Geiselman, USGS/BRD, 1011 E. Tudor Rd., Anchorage, AK 99503-6199].

Brew, D.A., and Ford, A.B., 1985, Preliminary reconnaissance geologic map of the Juneau, Taku River, Atlin, and part of the Skagway quadrangles, southeastern Alaska: U.S. Geological Survey Open-File Report 85-395, scale 1:250,000.

Brew, D.A., Ovenshine, A.T., Karl, S.M., and Hunt, S.J., 1984, Preliminary reconnaissance geologic map of the Petersburg and parts of the Port Alexander and Sumdum 1:250,000 quadrangles, southeastern Alaska: U.S. Geological Survey Open-File Report 84-405, 43 p., 2 sheets.

Buddington, A.F., and Chapin, Theodore, 1929, Geology and mineral deposits of southeastern Alaska: U.S. Geological Survey Bulletin 800, 398 p, 2 pls., scale 1:1,000,000.

Byrne, T., 1984, Early deformation in mélange terranes of the Ghost Rocks Formation, Kodiak Island, Alaska: Geological Society of America Special Paper 198, p. 21-51.

Carter, C., 1977, Age of the Hood Bay Formation, Alaska, in Sohl, N.F., and Wright, W.B., Changes in stratigraphic nomenclature by the U.S. Geological Survey, 1976: U.S. Geological Survey Bulletin 1435-A, p. A117-A118.

Churkin, M., Jr., and Eberlein, G.D., 1975, Geologic map of the Craig C-4 quadrangle, Alaska: U.S. Geological Survey Geologic Quadrangle Map GQ-1169, scale $1: 63,600$.

Cowan, D.S., 1982, Deformation of partly dewatered and consolidated Franciscan sediments near Piedras Blancas Point, California: Geological Society, London, Special Publications, v. 10, p. 439-457.

Dall'Agnol, R., and Carvalho de Olivera, D., 2007, Oxidized, magnetitie-series, rapakivi-type granites of Carajas, Brazil; implications for classification and petrogenesis of A-type granites: Lithos, v. 93, p. 215-233.
Dutro, J.T., and Douglass, R.C., 1961, Pennsylvanian rocks in southeastern Alaska, article 101 of Short papers in the geologic and hydrologic sciences: U.S. Geological Survey Professional Paper 424-B, p. B239-B241.

Eakin, H.M., 1919, The Porcupine gold placer district, Alaska: U.S. Geological Survey Bulletin 699, 29 p.

Eberlein, G.D., and Churkin, M., Jr., 1970, Paleozoic stratigraphy in the northwest coastal area of Prince of Wales Island, southeastern Alaska: U.S. Geological Survey Bulletin 1284, 67 p.

Eberlein, G.D., Churkin, M., Jr., Carter, C., Berg, H.C., and Ovenshine, A.T., 1983, Geology of the Craig quadrangle, Alaska: U.S. Geological Survey Open-File Report 83-91, 53 p., 4 sheets, scale 1:250,000.

Epstein, A.G., Epstein, J.B., and Harris, L.D., 1977, Conodont color alteration- an index to organic metamorphism: U.S.Geological Survey Professional Paper 995, 27 p.

Gilbert, W.G., Burns, L.E., Redman, E.C., and Forbes, R.B., 1987, Preliminary bedrock geology and geochemistry of the Skagway B-3 Quadrangle: Alaska Division of Geological and Geophysical Surveys Report of Investigations 87-2, 2 sheets, scale 1:36,200.

Gill, J., 1981, Orogenic andesites and plate tectonics: Berlin, Springer, $390 \mathrm{p}$.

Gradstein, F.M., Ogg, J.G., Smith, A.G., Agterberg, F.P., Bleeker, W., Cooper, R.A., Davydov, V., Gibbard, P., Hinnov, L., House, M.R., Lourens, L., Luterbacher, H-P., McArthur, J., Melchin, M.J., Robb, L.J., Shergold, J., Villeneuve, M., Plumb, K.A., Raffi, I., Rohl, U., Sanfilippo, A., Schmitz, B., Shackleton, N.J., Shields, G.A., Strauss, H., Van Dam, J., Veizer, J., van Kolfshoten, T., and Wilson, D., 2004, A geologic time scale 2004: Cambridge, U.K., Cambridge University Press, 500 p.

Grant, R.E., 1971, Taxonomy and autecology of two arctic Permian rhynchonellid brachiopods, in Dutro, J.T., Jr., ed., Paleozoic perspectives; a paleontologic tribute to G. Arthur Cooper ( Smithsonian Contributions to Paleobiology, no. 3): Washington, D.C., Smithsonian Institution Press, p. 313-335.

Green, D., and Greig, C., 2004, An exploration model for the Palmer VMS property, Haines area, Alaska [abs.]: Alaska Miners Association Annual Convention, Anchorage, 2004, Abstracts, p. 17.

Haeussler, P.J., Karl, S.M., Mortensen, J.K., Layer, P., and Himmelberg, G., 1999, Permian and mid-Cretaceous deformation of the Alexander terrane on Admiralty and Kupreanof Islands, southeastern Alaska [abs.]: Geological Society of America Abstracts with Programs, v. 31, no. 6, p. A-60. 
Hawley, C.C., 1976, Exploration and distribution of stratiform sulfide deposits in Alaska, in Miller, T.P., ed., Recent and ancient sedimentary environments: Alaska Geological Society Symposium, Anchorage, Proceedings, p. T1-T23.

Hill, M.D., 1979, Volcanic and plutonic rocks of the KodiakShumagin shelf, Alaska; subduction deposits and neartrench magmatism: Santa Cruz, University of California, Ph.D thesis, 274 p.

Hsu, K.J., 1968, Principles of mélanges and their bearing on the Franciscan-Knoxville paradox: Geological Society of America Bulletin, v. 79, v.8, p. 1063-1074.

Hudson, T., Plafker, G., and Dixon, K., 1981, Horizontal offset history of the Chatham Strait fault, in Coonrad, W.L., eds., The United States Geological Survey in Alaskaaccomplishments during 1980: U.S. Geological Survey Circular 844, p. 128-132.

Jones, D.L., Berg, H.C., Coney, P., and Harris, A.G., 1981, Structural and stratigraphic significance of Upper Devonian and Mississippian fossils from the Cannery Formation, Kupreanof Island, southeastern Alaska, in Albert, N.R.D., and Hudson, T., eds., United States Geological Survey in Alaska; accomplishments during 1979: U.S. Geological Survey Circular 823-B, p. B109-B112.

Journeay, J.M., Williams, S.P., and Wheeler, J.O., 2000, Tectonic assemblage map of Sitka, British ColumbiaU.S.A.: Geological Survey of Canada Open-File 2948h, scale $1: 1,000,000$.

Karl, S.M., 1982, Geochemical and depositional environments of Upper Mesozoic radiolarian cherts from the northeastern Pacific Rim and from Pacific DSDP cores: Stanford, Calif., Stanford University Ph.D thesis, 245 p., 3 pls.

Karl, S.M., Haeussler, P.J., Layer, P., and Himmelberg, G.R., 1998, Two new events in the metamorphic and deformational history of the Alexander terrane on admiralty Island, southeastern Alaska, in Karl, S.M., 1998, ed., Cutting Edge in Alaska: Alaska Geological Society Science and Technology Conference, Anchorage, Abstracts , p. 15.

Karl, S. M., 1999, Preliminary geologic map of northeast Chichagof Island, Alaska: U.S. Geological Survey OpenFile Report 96-53, 14 p., scale 1:63,360.

Karl, S.M., Haeussler, P.J., and McCafferty, A., 1999, Reconnaissance geologic map of the Duncan CanalZarembo Island area, southeastern Alaska: U.S. Geological Survey Open-File Report 99-168, scale 1:150,000 [http:// geopubs.wr.usgs.gov/open-file/of 99-168/].

Karl, S.M., Haeussler, P.J., Friedman, R.M., Mortensen, J.K., Himmelberg, G.R., and Zumsteg, C.L., 2006, Late Proterozoic ages for rocks on Mount Cheetdeekahyu and Admiralty Island, Alexander terrane, southeast
Alaska,[abs.]: Geological Society of America Abstracts with Programs, v. 38, no. 5, p. 20.

Kelemen, P.B., Hanghoj, K., and Greene, A.R., 2004, One view of the geochemistry of subduction-related magmatic arcs, with an emphasis on primitive andesite and lower crust, in Rudnick, R.L., ed., The crust, v. 3 of Holland, H.D., and Turekian, K.K., eds., Treatise on geochemistry: Oxford, U.K., Elsevier-Pergamon, p. 593-659.

Königshof, P., 2003, Conodont deformation patterns and textural alteration in Paleozoic conodonts; examples from Germany and France: Senckenbergiana lethaea, v. 83 , no. $1-2$, p. $149-156$.

Lanphere, M.A., and Dalrymple, G.B., 2000, First-principles calibration of $38 \mathrm{Ar}$ tracers; implications for the ages of 40Ar/39Ar fluence monitors: U.S. Geological Survey Professional Paper 1621, 10 p.

Laporte, C., Briqueu, L., Cluzel, D., and Eissen, J-P., 1998, Gradient isotopique le long de l'arc des Nouvelles Hebrides (Vanuatu, Pacifique sud-ouest); collision de la Zone d'Entrecasteaux et heterogenéité des sources mantelliques [Isotopic gradient along the New Hebrides arc (Vanuatu, SW Pacific); collision of the d'Entrecasteaux Zone and heterogeneity of mantle sources]: Earth and Planetary Sciences, v. 36, p. 101-106.

Lathram, E.H., Loney, R.L., Condon, W.H., and Berg, H.C., 1958, Progress map of the Juneau quadrangle, Alaska: U.S. Geological Survey Miscellaneous Investigations Map I-276, scale 1:250,000.

Lathram, E.H., Loney, R.L., Condon, W.H., and Berg, H.C., 1959, Progress map of the Juneau quadrangle, Alaska: U.S. Geological Survey Miscellaneous Investigations Map I-303, scale 1:250,000.

Lathram, E.H., Loney, R.A., Berg, H.C., and Pomeroy, J.S., 1960, Progress map of the geology of Admiralty Island, Alaska: U.S. Geological Survey Miscellaneous Geologic Investigations Map I-323, 1:250,000.

Lathram, E.H., Pomeroy, J.S., Berg, H.C., and Loney, R.A., 1965, Reconnaissance geology of Admiralty Island, Alaska: U.S. Geological Survey Bulletin 1181-R, p. R1-R48.

Layer, P.W., Hall, C.M., and York, D., 1987, The derivation of 40Ar/39Ar age spectra of single grains of hornblende and biotite by laser step heating: Geophysical Research Letters, v. 14 , p. $757-760$.

Loney, R.A., 1964, Stratigraphy and petrography of the Pybus-Gambier Bay area, Admiralty Island, Alaska: U.S. Geological Survey Bulletin 1178, 104 p.

Loney, R.A., Condon, W.H., and Dutro, J.T., Jr., 1963, Geology of the Freshwater Bay area, Chichagof Island, Alaska: U.S. Geological Survey Bulletin 1108-C, p. C1-C51. 
Loney, R.A., Brew, D.A., Muffler, L.J.P., and Pomeroy, J.S., 1975, Reconnaissance geology of Chichagof, Baranof, and Kruzof Islands, southeastern Alaska: U.S. Geological Survey Professional Paper 792, 105 p.

MacIntyre, D.G., 1983, Geological fieldwork, 1982: British Columbia, Canada Ministry of Energy, Mines and Petroleum Resources Paper 1983-1, p. 149-170.

MacIntyre, D.G., 1984, Geology of the Alsek-Tatshenshini Rivers area (114P), Geological fieldwork, 1983: British Columbia, Canada, Ministry of Energy, Mines and Petroleum Resources Paper 1984-1, p. 173-184.

McClelland, W.C., and Gehrels, G.E., 1990, Geology of the Duncan Canal shear zone; evidence for Early to Middle Jurassic deformation of the Alexander terrane, southeastern Alaska: Geology of America Society Bulletin, v. 102, p. 1378-1392.

McDermott, F., Defant, M.J., Hawkesworth, C.J., Maury, R.C., and Joron, J.L., 1993, Isotope and trace element evidence for three component mixing in the genesis of the North Luzon lavas (Philippines): Contributions to Mineralogy and Petrology, v. 113, p. 9-23.

McDougall, I. and Harrison, T.M., 1999, Geochronology and thermochronology by the 40Ar/39Ar method ( $2 \mathrm{~d}$ ed.): New York, Oxford University Press, 269 p.

Mihalynuk, M.G., Smith, M.T., MacIntyre, D.G., Deschenes, M., Timmerman, J., and Schiarizza, P., 1993, Northwest Tatshenshini River map area, Northwestern British Columbia: British Columbia, Canada, Ministry of Energy, Mines and Petroleum Resources Open File 1993-13, scale 1:50,000, 6 sheets.

Muffler, J.P., 1967, Stratigraphy of the Keku Islets and neighboring parts of Kuiu and Kupreanof Islands, southeastern Alaska: U.S. Geological Survey Bulletin 1241-C, p. C1-C52.

Mutti, E., and Ricchi Lucchi, F., 1972, Le torbidite dell'Appennino setentrionale - introduzione all'analisi de facies: Società Geologica Italiana Memorie, v. 11, p. 161-199.

Miyashiro, A., 1973, Metamorphism and metamorphic belts: London, George Allen and Unwin, 492 p.

Nelson, S.W., and Blome, C.D., 1991, Preliminary geochemistry of volcanic rocks from the McHugh Complex and Kachemak terrane, southern Alaska: U.S. Geological Survey Open-File Report 91-134, 15 p.

Nokleberg, W.J., Parfenov, L.M., Monger, J.W.H., Norton, I.O., Khanchuk, A.I., Stone, D.B., Scotese, C.R., Scholl, D.W., and Fujita, K., 2000, Phanerozoic tectonic evolution of the circum-North Pacific: U.S. Geological Survey Professional Paper 1626, 122 p.

Pearce, J.A., 1982, Trace element characteristics of lavas from destructive plate boundaries, in Thorpe, R.S., Andesites; orogenic andesites and related rocks: Chichester, U.K., John Wiley and Sons, p. 525-547.

Pearce, J.A., Harris, B.W., and Tindle, A.G., 1984, Trace element discrimination diagrams for the tectonic interpretation of granitic rocks: Journal of Petrology,

v. 25 , p. 956-983.

Pearce, J.A., and Norry, M.J., 1979, Petrogenetic imnplications of $\mathrm{Ti}, \mathrm{Zr}, \mathrm{Y}$, and $\mathrm{Nb}$ variations in volcanic rocks: Contributions to Minerology and Petrology, v. 69, p. 33-47.

Pearce, J.A., and Peate, D.W., 1995, Tectonic implications of the composition of arc magmas: Annual Review of Earth and Planetary Sciences, v. 23, p. 251-285.

Peter, J.M., and Scott, S.D., 1999, Windy Craggy, northwestern British Columbia; the world's largest Bessi-type deposit, in Barrie, C.T., and Hannington, M.D., eds., Volcanic-associated massive sulfide deposits: processes and examples in modern and ancient settings: Reviews in Economic Geology, v. 8, p. 261-295.

Plafker, G., Jones, D.L., and Pessagno, E.A., Jr., 1977, A Cretaceous accretionary flysch and melange terrane along the Gulf of Alaska margin, in Blean, K.M., ed., The United States Geological Survey in Alaska - accomplishments during 1976: U.S. Geological Survey Circular 751-B, p. B41-B43.

Redman, E.C., Gilbert, W.G., Jones, B.K., Rosenkrans, D.S., and Hickok, B.D., 1985, Preliminary bedrock geologic map of the Skagway B-4 quadrangle: Alaska Division of Geological and Geophysical Surveys Report of Investigations 84-31, scale 1:40,000.

Rowett, C.L., 1975, Stratigraphic distribution of Permian corals in Alaska: U.S. Geological Survey Professional Paper 823-D, p. 59-75.

Samson, S.D., and Alexander, E.C., 1987, Calibration of the interlaboratory 40Ar/39Ar dating standard, MMhb1: Chemical Geology, v. 66, p. 27-34.

Savage, N.M., and Barkeley, S.J., 1985, Early to Middle Pennsylvanian conodonts from the Klawak Formation and the Ladrones Limestone, southeastern Alaska: Journal of Paleontology, v. 59, p. 1451-1475.

Steiger, R.H., and Jaeger, E., 1977, Subcommission on geochronology; convention on the use of decay constants in geo and cosmochronology: Earth and Planet Science Letters, v. 36, p. 359-362. 
Still, J.C., 1984, Stratiform massive sulfide deposits of Mt. Henry Clay area, southeast Alaska: U.S.Bureau of Mines Open-File Report 118-84, $10 \mathrm{p}$.

Walker, J.D., and Geissman, J.W., compilers, 2009, Geologic time scale: Boulder, Colo., Geologic Society of America, doi:10.1130/2009.CTS004R2C.

Watson, K.D., 1948, The Squaw Creek-Rainy Hollow area, northern British Columbia: British Columbia, Canada, Department of Mines and Petroleum Resources Bulletin 25, 74 p.

Whalen, J.B., Currie, K.L., and Chappell, B.W., 1987, A-type granites: geochemical characteristics, discrimination, and petrogenesis: Contributions to Mineralogy and Petrology, v. 95, p. 407-419.

Winchester, J.A., and Floyd, P.A., 1977, Geochemical discrimination of different magma series and their differentiation products using immobile elements: Chemical Geology, v. 20 , no. 4 , p. 325-343.
Wood, D.A., 1980, The application of a Th-Hf-Ta diagram to problems of tectonomagmatic classification and to establishing the nature of crustal contamination of basaltic lavas of the British Tertiary Volcanic Province: Earth and Planetary Science Letters, v. 50, p. 11-30.

Wright, C.W., 1904, Porcupine placer district, Alaska: U.S. Geological Survey Bulletin 236, 35 p.

Wright, C.W., 1906, A reconnaissance of Admiralty Island: U.S. Geological Survey Bulletin 287, p. $138-154$.

Wright, F.E., and Wright, C.W., 1908, Ketchikan and Wrangell mining districts, Alaska: U.S. Geological Survey Bulletin 347, 210 p., 3 pls., scales 1:250,000, 1:900,000.

York, D., Hall, C.M., Yanase, Y., Hanes, J.A., and Kenyon, W.J., 1981, 40Ar/39Ar dating of terrestrial minerals with a continuous laser: Geophysical Research Letters, v. 8, p. 1136-1138. 

Appendix 
Appendix. Argon analytical data for Permian metamorphic and igneous rocks in the Alexander terrane, southeastern Alaska.

\begin{tabular}{|c|c|c|c|c|c|c|c|c|c|c|}
\hline $\begin{array}{l}\text { Laser } \\
\text { Power } \\
\text { (mWatt) }\end{array}$ & $\begin{array}{c}\text { Cumulative } \\
{ }^{39} \mathrm{Ar}\end{array}$ & $\begin{array}{l}{ }^{40} \mathrm{Ar} /{ }^{\beta 9} \mathrm{Ar} \\
\text { measured }\end{array}$ & $\begin{array}{l}{ }^{37} \mathrm{Ar} /{ }^{\beta 9} \mathrm{Ar} \\
\text { measured }\end{array}$ & $\begin{array}{l}{ }^{36} \mathrm{Ar} /{ }^{\beta 9} \mathrm{Ar} \\
\text { measured }\end{array}$ & $\begin{array}{c}\% \text { Atmospheric } \\
{ }^{40} \mathrm{Ar}\end{array}$ & $\mathrm{Ca} / \mathrm{K}$ & $\mathrm{Cl} / \mathrm{K}$ & $40 * \beta 9 \mathrm{~K}$ & $\begin{array}{l}\text { Age } \\
\text { (Ma) }\end{array}$ & $\begin{array}{c}+/- \\
(\mathrm{Ma})\end{array}$ \\
\hline 100 & 0.0015 & 38.629 & 0.292 & 0.146 & 112.09 & 0.292 & \multirow{12}{*}{$\begin{array}{c}\text { not } \\
\text { available }\end{array}$} & -4.668 & -60.5312 & 241.2301 \\
\hline 200 & 0.0116 & 10.522 & 1.509 & 0.022 & 60.913 & 1.511 & & 4.105 & 51.6107 & 41.2993 \\
\hline 400 & 0.1146 & 10.559 & 0.309 & 0.004 & 10.193 & 0.309 & & 9.459 & 116.7672 & 2.6832 \\
\hline 500 & 0.4099 & 19.501 & 0.016 & 0.003 & 4.883 & 0.016 & & 18.521 & 221.971 & 2.7658 \\
\hline 600 & 0.4768 & 19.701 & 0.011 & 0.003 & 4.46 & 0.011 & & 18.795 & 225.056 & 4.3087 \\
\hline 700 & 0.5118 & 15.889 & 0.025 & -0.004 & -7.304 & 0.025 & & 17.019 & 204.9538 & 11.0312 \\
\hline 800 & 0.5853 & 18.825 & 0.01 & -0.001 & -1.181 & 0.01 & & 19.019 & 227.5713 & 4.8496 \\
\hline 1000 & 0.7309 & 19.619 & 0.012 & 0.001 & 1.633 & 0.012 & & 19.271 & 230.4021 & 2.9347 \\
\hline 1500 & 0.8155 & 17.923 & 0.135 & -0.001 & -1.304 & 0.135 & & 18.13 & 217.55 & 4.4537 \\
\hline 2000 & 0.8417 & 21.47 & 0.07 & 0 & -0.274 & 0.07 & & 21.5 & 255.2579 & 13.7878 \\
\hline 9000 & 1 & 25.645 & 0.019 & 0.011 & 12.839 & 0.019 & & 22.328 & 264.3922 & 3.5741 \\
\hline Integrated & & 19.262 & 0.073 & 0.004 & 5.549 & 0.073 & & 18.167 & 217.9696 & 1.4989 \\
\hline
\end{tabular}

Sample: 93PH127B, University of Maine

mineral analyzed: white mica

$\mathrm{J}=0.00659$, error not available

\begin{tabular}{|c|c|c|c|c|c|c|c|c|c|c|}
\hline Temp $\left({ }^{\circ} \mathrm{C}\right)$ & $\begin{array}{c}\text { Cumulative } \\
{ }^{39} \mathrm{Ar}\end{array}$ & $\begin{array}{l}{ }^{40} \mathrm{Ar} /{ }^{\beta 9} \mathrm{Ar} \\
\text { measured }\end{array}$ & $\begin{array}{l}{ }^{37} \mathrm{Ar} /{ }^{39} \mathrm{Ar} \\
\text { measured }\end{array}$ & $\begin{array}{c}{ }^{36} \mathrm{Ar} /{ }^{39} \mathrm{Ar} \\
\text { measured }\end{array}$ & Moles ${ }^{39} \mathrm{Ar}$ & $\mathrm{Ca} / \mathrm{K}$ & $\mathrm{Cl} / \mathrm{K}$ & $\begin{array}{c}\text { Radio-genic } \\
\text { yield (\%) }\end{array}$ & $\begin{array}{l}\text { Age } \\
\text { (Ma) }\end{array}$ & $\begin{array}{c}+/- \\
(\mathrm{Ma})\end{array}$ \\
\hline 775 & 0.061 & 16.87 & 0.023 & 0.0028 & 146.1 & 0.046761749 & \multirow{5}{*}{$\begin{array}{c}\text { not } \\
\text { available }\end{array}$} & 95.1 & 181.3 & 1.8 \\
\hline 940 & 0.225 & 22.96 & 0.019 & 0.0014 & 543.2 & 0.038856077 & & 98.1 & 249.7 & 2.4 \\
\hline 1030 & 0.303 & 23.46 & 0.039 & 0.0013 & 732.8 & 0.08033419 & & 98.3 & 255.3 & 2.6 \\
\hline fuse & 0.071 & 24.86 & 0.062 & 0.0016 & 170.7 & 0.127000254 & & 98.1 & 268.9 & 2.7 \\
\hline Total & 1.000 & & & & 2414.9 & & & & 246.2 & 2.5 \\
\hline
\end{tabular}

Sample: 96SK013A, UAF Sample number: UAF068-36

mineral analyzed: white mica

Weighted average of $\mathrm{J}$ from standards $=0.008468+/-0.000036$

\begin{tabular}{|c|c|c|c|c|c|c|c|c|c|c|}
\hline $\begin{array}{l}\text { Laser } \\
\text { Power } \\
\text { (mW) }\end{array}$ & $\begin{array}{l}\text { Cumulative } \\
{ }^{39} \mathrm{Ar}\end{array}$ & $\begin{array}{l}{ }^{40} \mathrm{Ar} /{ }^{\beta 9} \mathrm{Ar} \\
\text { measured }\end{array}$ & $\begin{array}{l}{ }^{37} \mathrm{Ar} /{ }^{\beta 9} \mathrm{Ar} \\
\text { measured }\end{array}$ & $\begin{array}{l}{ }^{36} \mathrm{Ar} /{ }^{\beta 9} \mathrm{Ar} \\
\text { measured }\end{array}$ & $\underset{{ }^{40} \mathrm{Ar}}{\% \text { Atmospheric }}$ & $\mathrm{Ca} / \mathrm{K}$ & $\mathrm{Cl} / \mathrm{K}$ & ${ }^{40 *} \beta^{9} \mathrm{~K}$ & $\begin{array}{l}\text { Age } \\
\text { (Ma) }\end{array}$ & $\begin{array}{l}+/- \\
(\mathrm{Ma})\end{array}$ \\
\hline 150 & 0.0002 & 81.21374 & 4.2257 & 0.03779 & 13.36443 & 7.77496 & -0.01154 & 70.52921 & 844.81 & 477.15 \\
\hline 300 & 0.0012 & 31.41048 & -0.07985 & 0.07783 & 73.30371 & -0.1465 & 0.00021 & 8.37734 & 123.64 & 187.23 \\
\hline 600 & 0.0089 & 16.65318 & 0.06797 & 0.0105 & 18.63848 & 0.12472 & 0.00008 & 13.52653 & 195.64 & 20.02 \\
\hline 900 & 0.0488 & 18.34407 & -0.00526 & 0.00246 & 3.96875 & -0.00965 & 0.0007 & 17.58842 & 250.48 & 3.71 \\
\hline 1000 & 0.1174 & 18.15637 & -0.00644 & 0.00215 & 3.5155 & -0.01182 & 0.00016 & 17.49032 & 249.17 & 3.44 \\
\hline 1250 & 0.2171 & 19.50602 & -0.03185 & -0.00009 & -0.11973 & -0.05845 & 0.00005 & 19.50024 & 275.72 & 3.31 \\
\hline 1500 & 0.4233 & 19.03369 & -0.01595 & -0.00064 & -0.9965 & -0.02927 & 0.00018 & 19.19418 & 271.7 & 1.22 \\
\hline 1750 & 0.4409 & 17.90656 & -0.03581 & -0.00142 & -2.32743 & -0.0657 & 0.00006 & 18.29352 & 259.83 & 12.5 \\
\hline 2000 & 0.4468 & 16.15149 & -0.43874 & 0.00098 & 2.00627 & -0.80481 & -0.0021 & 15.79481 & 226.47 & 34.24 \\
\hline 2500 & 0.4553 & 15.73961 & -0.32145 & -0.00355 & -6.5149 & -0.5897 & 0.00012 & 16.73096 & 239.04 & 26.21 \\
\hline 3000 & 0.6454 & 18.19726 & -0.02224 & -0.00004 & -0.05114 & -0.04081 & 0.0002 & 18.17759 & 258.29 & 1.22 \\
\hline 3500 & 0.7989 & 18.34725 & -0.01104 & -0.00054 & -0.86689 & -0.02026 & 0.00019 & 18.47722 & 262.26 & 1.81 \\
\hline 4500 & 0.8665 & 17.52531 & -0.02737 & 0.00107 & 1.81802 & -0.05022 & 0.00005 & 17.17821 & 245.01 & 5.27 \\
\hline 9000 & 1 & 17.62192 & -0.01705 & -0.00039 & -0.64739 & -0.03128 & 0.00028 & 17.70692 & 252.05 & 1.99 \\
\hline Integrated & & 18.38226 & -0.02165 & 0.00015 & 0.25274 & -0.03972 & 0.00018 & 18.30692 & 260 & 1.36 \\
\hline
\end{tabular}


Appendix. Argon analytical data for Permian metamorphic and igneous rocks in the Alexander terrane, southeastern Alaska.-Continued

Sample: 97PH045B, UAF Sample number: UAF068-36

mineral analyzed: white mica

Weighted average of $\mathrm{J}$ from standards $=0.009587+/-0.00003 .817$

\begin{tabular}{|c|c|c|c|c|c|c|c|c|c|c|}
\hline $\begin{array}{l}\text { Laser } \\
\text { Power } \\
\text { (mW) }\end{array}$ & $\begin{array}{l}\text { Cumulative } \\
{ }^{39} \mathrm{Ar}\end{array}$ & $\begin{array}{l}{ }^{40} \mathrm{Ar} /{ }^{\beta 9} \mathrm{Ar} \\
\text { measured }\end{array}$ & $\begin{array}{l}{ }^{37} \mathrm{Ar} /{ }^{39} \mathrm{Ar} \\
\text { measured }\end{array}$ & $\begin{array}{l}{ }^{36} \mathrm{Ar} /{ }^{\beta 9} \mathrm{Ar} \\
\text { measured }\end{array}$ & $\begin{array}{c}\% \\
\text { Atmospheric } \\
{ }^{40} \mathrm{Ar}\end{array}$ & $\mathrm{Ca} / \mathrm{K}$ & $\mathrm{Cl} / \mathrm{K}$ & $40 * \beta^{99} \mathrm{~K}$ & $\begin{array}{l}\text { Age } \\
\text { (Ma) }\end{array}$ & $\begin{array}{l}+/- \\
(\mathrm{Ma})\end{array}$ \\
\hline 150 & 0.0022 & 26.1387 & 0.90209 & 0.06162 & 69.5 & 1.6562 & 0.00244 & 7.974 & 132.9 & 11.0 \\
\hline 200 & 0.0041 & 18.8683 & 1.08873 & 0.03025 & 47.0 & 1.9991 & 0.00087 & 9.990 & 165.0 & 18.0 \\
\hline 300 & 0.0189 & 19.8672 & 0.08483 & 0.01191 & 17.7 & 0.1557 & 0.00082 & 16.327 & 262.3 & 1.8 \\
\hline 750 & 0.1789 & 17.3902 & 0.04232 & 0.00585 & 9.9 & 0.0777 & 0.00053 & 15.636 & 252.0 & 0.7 \\
\hline 900 & 0.2480 & 17.5447 & 0.00910 & 0.00224 & 3.8 & 0.0167 & 0.00044 & 16.856 & 270.2 & 1.1 \\
\hline 1050 & 0.3488 & 17.8893 & 0.02454 & 0.00494 & 8.2 & 0.0450 & 0.00047 & 16.403 & 263.5 & 1.2 \\
\hline 3500 & 0.9093 & 18.2418 & 0.00722 & 0.00335 & 5.4 & 0.0133 & 0.00026 & 17.225 & 275.7 & 0.9 \\
\hline 6000 & 1.0000 & 17.0024 & 0.01100 & 0.00348 & 6.1 & 0.0202 & 0.00047 & 15.945 & 256.6 & 0.7 \\
\hline Integrated & & 17.3940 & 0.01956 & 0.00374 & 6.3 & 0.0359 & 0.00047 & 16.263 & 261.4 & 1.1 \\
\hline
\end{tabular}

Sample: 97PH055B, UAF Sample number: UAF072-27

mineral analyzed: hornblende

Weighted average of $\mathrm{J}$ from standards $=0.009587+/-0.00003 .817$

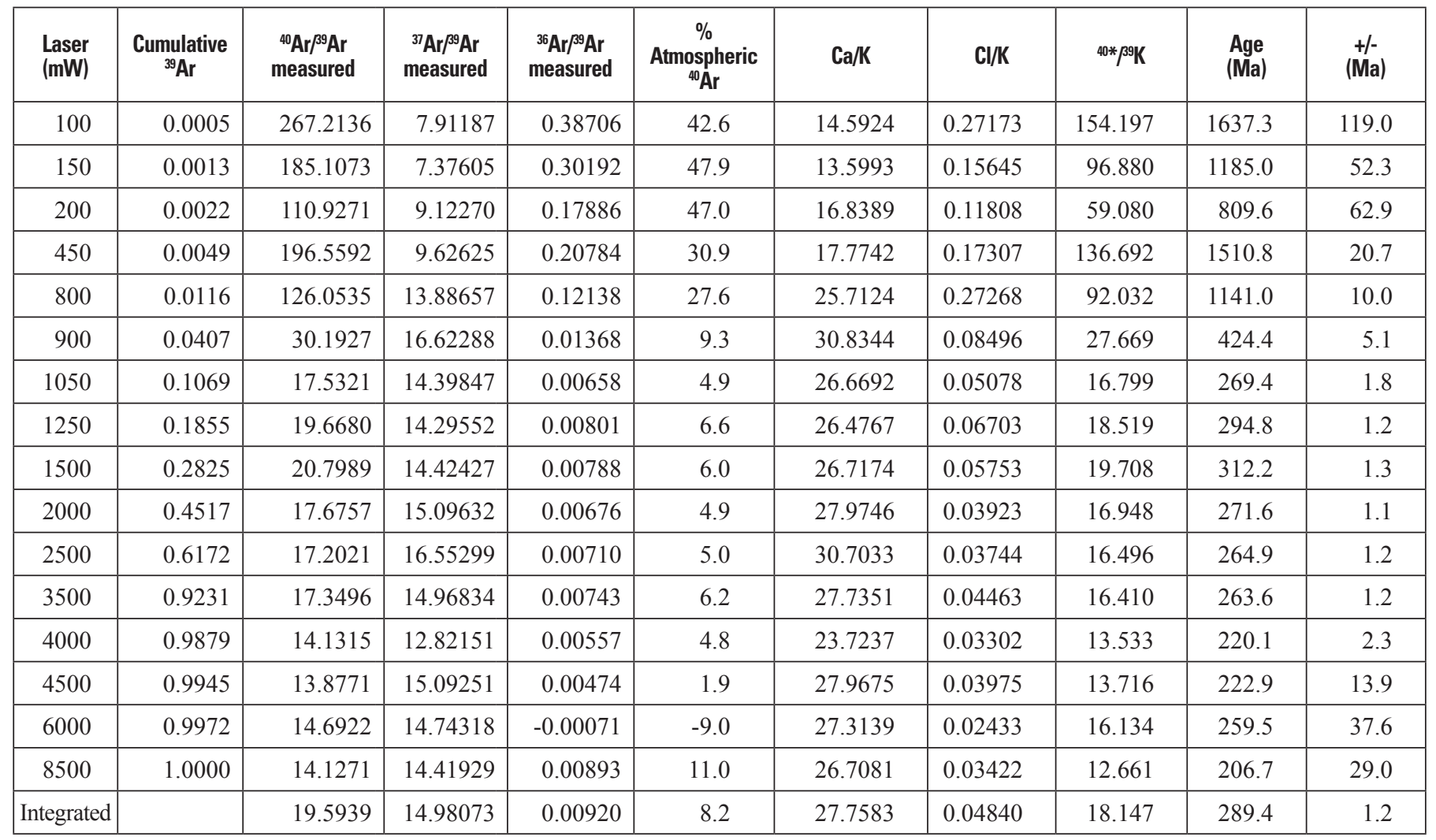


Appendix. Argon analytical data for Permian metamorphic and igneous rocks in the Alexander terrane, southeastern Alaska.-Continued

Sample: 91SK168A, UAF Sample number: UAF061-08

mineral analyzed: white mica

Weighted average of $\mathrm{J}$ from standards $=0.007069+/-0.000014$

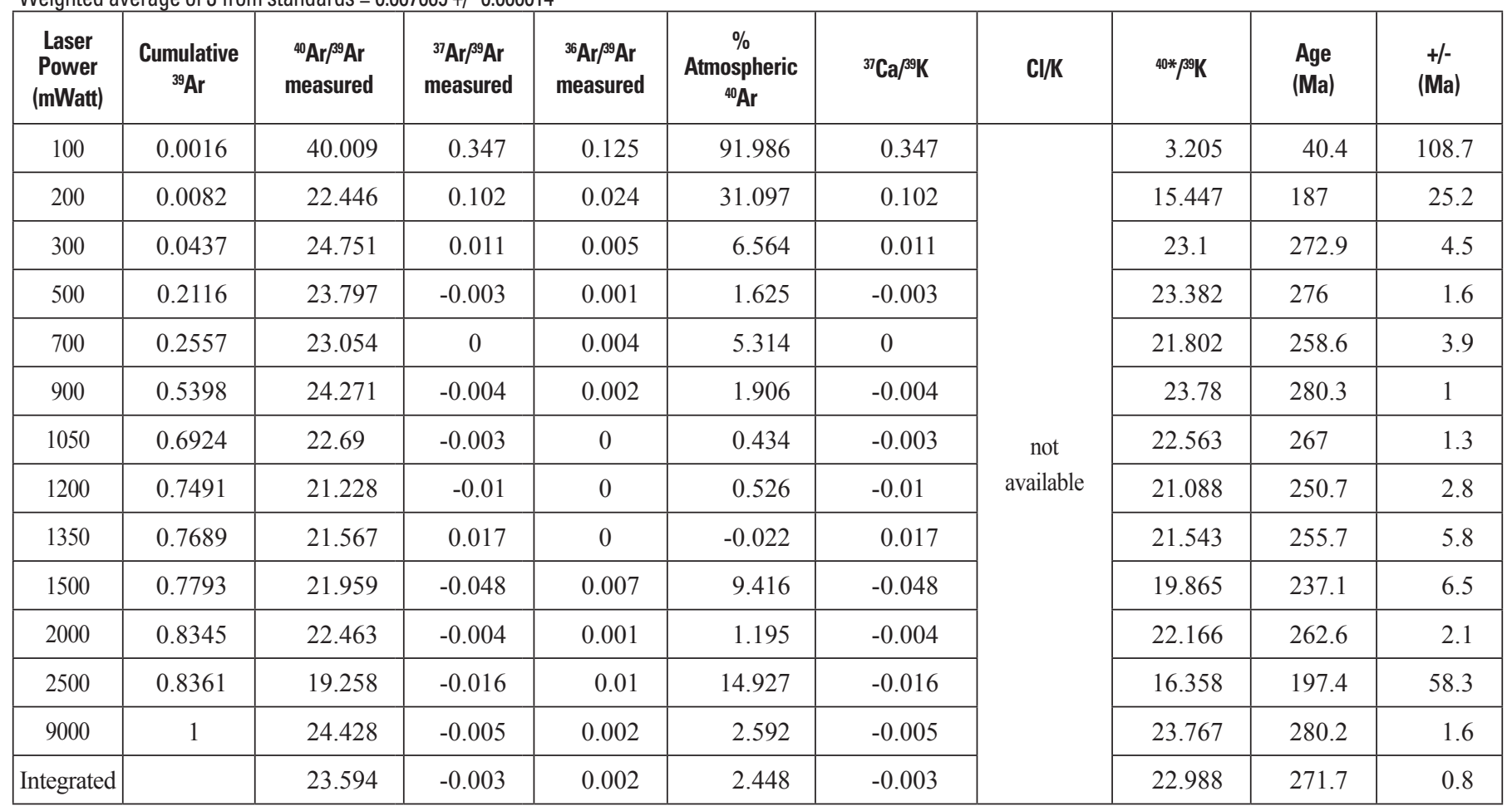

Sample number: 91SK168A, UAF sample number: UAF061-08

mineral analyzed: white mica

Weighted average of $\mathrm{J}$ from standards $=0.007069+/-0.000014$

\begin{tabular}{|c|c|c|c|c|c|c|c|c|c|c|}
\hline $\begin{array}{l}\text { Laser } \\
\text { Power } \\
\text { (mWatt) }\end{array}$ & $\begin{array}{c}\text { Cumulative } \\
{ }^{39} \mathrm{Ar}\end{array}$ & $\begin{array}{l}{ }^{40} \mathrm{Ar} /{ }^{\beta 9} \mathrm{Ar} \\
\text { measured }\end{array}$ & $\begin{array}{l}{ }^{37} \mathrm{Ar} /{ }^{39} \mathrm{Ar} \\
\text { measured }\end{array}$ & $\begin{array}{l}{ }^{36} \mathrm{Ar} /{ }^{\beta 9} \mathrm{Ar} \\
\text { measured }\end{array}$ & $\begin{array}{c}\% \\
\text { Atmospheric } \\
{ }^{40} \mathrm{Ar}\end{array}$ & ${ }^{37} \mathrm{Ca} /{ }^{\beta 9} \mathrm{~K}$ & $\mathrm{Cl} / \mathrm{K}$ & ${ }^{40 *} \beta{ }^{99} \mathrm{~K}$ & $\begin{array}{l}\text { Age } \\
\text { (Ma) }\end{array}$ & $\begin{array}{c}+/- \\
(\mathrm{Ma})\end{array}$ \\
\hline 200 & 0.0043 & 59.908 & 0.165 & 0.19 & 93.789 & 0.165 & \multirow{9}{*}{$\begin{array}{c}\text { not } \\
\text { available }\end{array}$} & 3.72 & 46.8252 & 177.4504 \\
\hline 400 & 0.3251 & 28.583 & -0.002 & 0.008 & 8.594 & -0.002 & & 26.1 & 305.4752 & 1.9414 \\
\hline 700 & 0.8181 & 26.099 & 0.041 & 0.028 & 31.185 & 0.041 & & 17.941 & 215.4139 & 49.7254 \\
\hline 800 & 0.8247 & 23.221 & 0.125 & 0.065 & 82.4 & 0.125 & & 4.082 & 51.3235 & 92.6786 \\
\hline 1000 & 0.8355 & 22.44 & -0.101 & 0.023 & 31.011 & -0.101 & & 15.46 & 187.118 & 59.8095 \\
\hline 1250 & 0.9017 & 24.748 & -0.006 & 0.001 & 1.226 & -0.006 & & 24.416 & 287.2498 & 9.4787 \\
\hline 2500 & 0.987 & 23.401 & 0.019 & -0.001 & -1.002 & 0.019 & & 23.607 & 278.4289 & 23.3648 \\
\hline 9000 & 1 & 26.012 & -0.054 & 0.007 & 7.788 & -0.054 & & 23.959 & 282.2686 & 36.0968 \\
\hline Integrated & & 26.441 & -0.002 & 0.006 & 7.231 & -0.002 & & 24.502 & 288.1822 & 2.1768 \\
\hline
\end{tabular}


Appendix. Argon analytical data for Permian metamorphic and igneous rocks in the Alexander terrane, southeastern Alaska.-Continued

Sample number: 91SK047A, UAF Sample number: UAF087-25

mineral analyzed: biotite

Weighted average of $\mathrm{J}$ from standards $=0.002516+/-0.000015$

\begin{tabular}{|c|c|c|c|c|c|c|c|c|c|c|}
\hline $\begin{array}{l}\text { Laser } \\
\text { Power } \\
(\mathrm{mW})\end{array}$ & $\begin{array}{c}\text { Cumulative } \\
{ }^{39} \mathrm{Ar}\end{array}$ & $\begin{array}{l}{ }^{40} \mathrm{Ar} /{ }^{\beta 9} \mathrm{Ar} \\
\text { measured }\end{array}$ & $\begin{array}{l}{ }^{37} \mathrm{Ar} /{ }^{\beta 9} \mathrm{Ar} \\
\text { measured }\end{array}$ & $\begin{array}{l}{ }^{36} \mathrm{Ar} /{ }^{\beta 9} \mathrm{Ar} \\
\text { measured }\end{array}$ & $\begin{array}{c}\% \\
\text { Atmospheric } \\
{ }^{40} \mathrm{Ar}\end{array}$ & $\mathrm{Ca} / \mathrm{K}$ & $\mathrm{Cl} / \mathrm{K}$ & ${ }^{40 *} \beta^{99} \mathrm{~K}$ & $\begin{array}{l}\text { Age } \\
\text { (Ma) }\end{array}$ & $\begin{array}{c}+/- \\
\text { (Ma) }\end{array}$ \\
\hline 300 & 0.0007 & 42.110 & 1.2225 & 0.0351 & 24.4 & 2.2450 & 0.0155 & 31.83 & 139.0 & 18.7 \\
\hline 500 & 0.0033 & 45.644 & 0.5543 & 0.0253 & 16.3 & 1.0173 & 0.0174 & 38.19 & 165.5 & 3.1 \\
\hline 900 & 0.0398 & 67.939 & 0.0242 & 0.0064 & 2.8 & 0.0443 & 0.0193 & 66.01 & 277.2 & 0.4 \\
\hline 1100 & 0.0791 & 67.075 & 0.0148 & 0.0020 & 0.9 & 0.0271 & 0.0194 & 66.45 & 278.9 & 0.5 \\
\hline 1300 & 0.1289 & 66.964 & 0.0122 & 0.0010 & 0.4 & 0.0225 & 0.0192 & 66.65 & 279.7 & 0.4 \\
\hline 1500 & 0.1885 & 66.968 & 0.0132 & 0.0007 & 0.3 & 0.0242 & 0.0194 & 66.75 & 280.1 & 0.3 \\
\hline 3000 & 0.6619 & 67.120 & 0.0667 & 0.0002 & 0.1 & 0.1224 & 0.0203 & 67.03 & 281.2 & 0.5 \\
\hline 3500 & 0.8438 & 66.933 & 0.1156 & 0.0001 & 0.0 & 0.2121 & 0.0215 & 66.88 & 280.6 & 0.7 \\
\hline 8700 & 1.0000 & 66.879 & 0.2938 & 0.0007 & 0.3 & 0.5392 & 0.0261 & 66.69 & 279.8 & 0.4 \\
\hline Integrated & & 66.965 & 0.0930 & 0.0009 & 0.4 & 0.1707 & 0.0210 & 66.68 & 279.8 & 1.6 \\
\hline
\end{tabular}

Sample number: 91SK040A, UAF Sample number: UAF087-24

Weighted average of $\mathrm{J}$ from standards $=0.002516+/-0.000015$

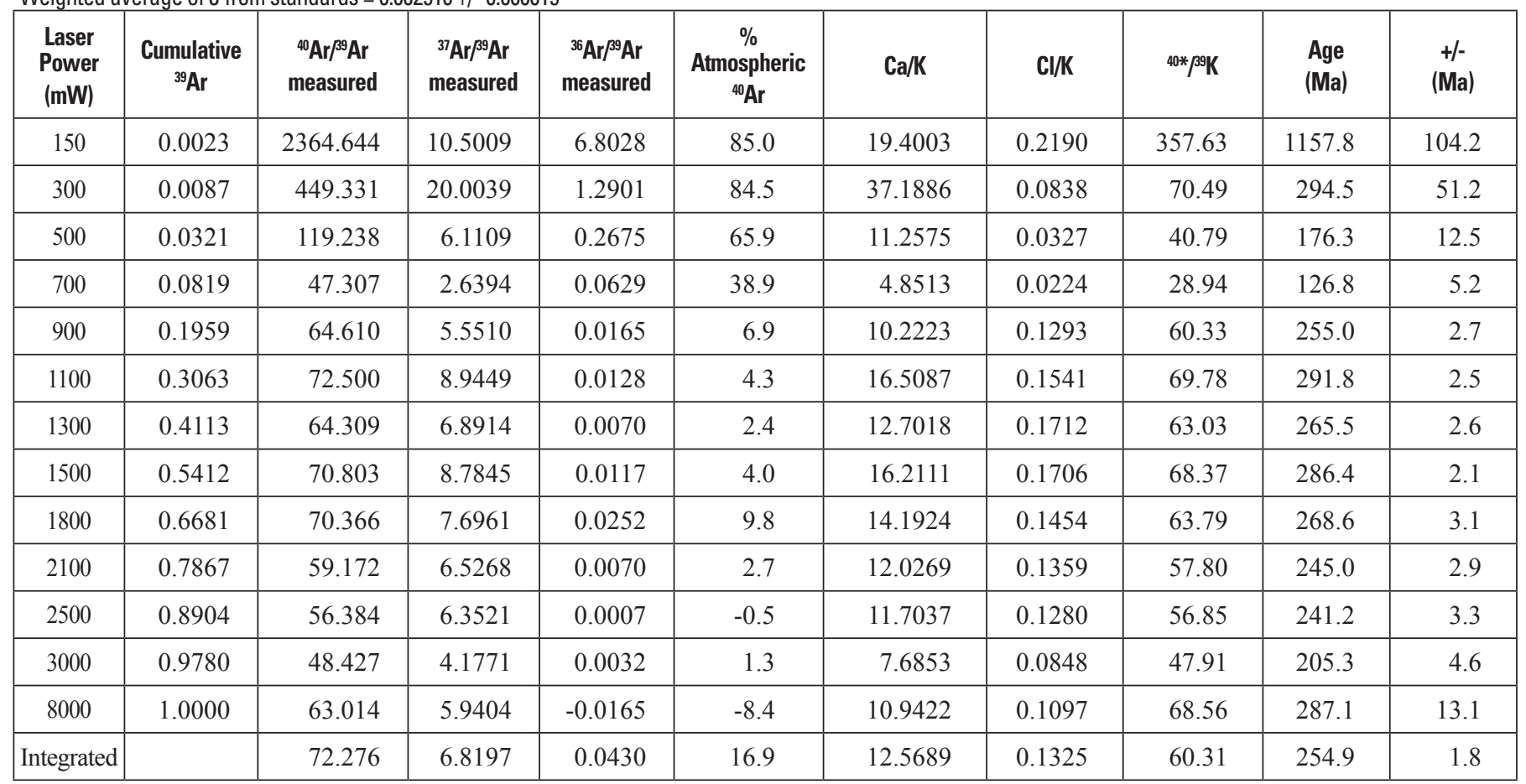



Produced in the Western Region, Menlo Park, California Manuscript approved for publication, June 11, 2010

Text edited by George Havach

Layout and design by Jeanne S. DiLeo 


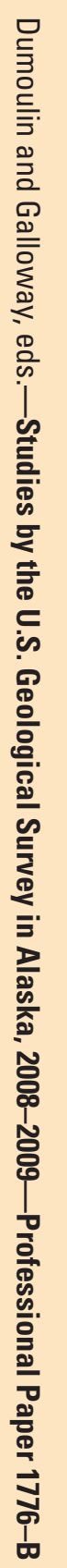

